\title{
Psychological Adjustment to Cleft Lip and/or Palate: A Narrative Review of the Literature
}

\section{Nicola Marie Stock \& Kristin Billaud Feragen}

To cite this article: Nicola Marie Stock \& Kristin Billaud Feragen (2016): Psychological Adjustment to Cleft Lip and/or Palate: A Narrative Review of the Literature, Psychology \& Health, DOI: $10.1080 / 08870446.2016 .1143944$

To link to this article: http://dx.doi.org/10.1080/08870446.2016.1143944

Accepted author version posted online: 22

Jan 2016.

Submit your article to this journal $[\pi$

Џ Article views: 19

Q View related articles $\asymp$

View Crossmark data 
Publisher: Taylor \& Francis

Journal: Psychology \& Health

DOI: http://dx.doi.org/10.1080/08870446.2016.1143944

Psychological Adjustment to Cleft Lip and/or Palate: A Narrative Review of the Literature

Corresponding author: Dr Nicola Marie Stock (DPhil)

Affiliations: Centre for Appearance Research, University of the West of England, Bristol, United Kingdom

Postal address: Centre for Appearance Research, University of the West of England, Frenchay Campus, Bristol, BS16 1QY, United Kingdom

Telephone number: $+44(0) 1173287929$

Email address: Nicola2.Stock@uwe.ac.uk

Co-author: Dr Kristin Billaud Feragen $(\mathrm{PhD})$

Affiliations: Senter for sjeldne diagnoser (Centre for Rare Disorders), Oslo Universitetssykehus HF, Oslo, Norway

Postal address: Senter for sjeldne diagnoser (Centre for Rare Disorders), Oslo Universitetssykehus HF, Rikshospitalet, Postboks 4950 Nydalen, 0424 Oslo, Norway

Telephone number: +4722902885

Email address: krifer@ous-hf.no

We have no financial interest or benefit arising from the direct applications of this research. 


\title{
Psychological Adjustment to Cleft Lip and/or Palate: A Narrative Review of the
}

\section{Literature}

\begin{abstract}
Objective: Adjustment to cleft lip and/or palate (CL/P) is multifaceted, involving several domains of psychological and social functioning. A substantial increase in research in this area has been evident in recent years, along with a preliminary shift in how adjustment to $\mathrm{CL} / \mathrm{P}$ is conceptualised and measured. An updated and comprehensive review of the literature is needed in light of the rapidly expanding and changing field.
\end{abstract}

Design: A narrative review of 148 quantitative and qualitative studies published between January 2004 - July 2015.

Main Outcome Measures: Findings are presented according to five key domains of adjustment: Developmental Trajectory, Behaviour, Emotional Wellbeing, Social Experiences and Satisfaction with Appearance and Treatment. Data pertaining to General Psychological Wellbeing were also examined.

Results: The overall impact of CL/P on psychological adjustment appears to be low. Nonetheless, the review demonstrates the complexity of findings both within and across domains, and highlights recurring methodological challenges.

Conclusions: Research findings from the last decade are considered to be largely inconclusive, although some areas of emerging consensus and improvements in the approaches used were identified. Efforts to collect data from large, representative and longitudinalsamples, which are comparable across studies and encompassing of the patient perspective, should be doubled.

Keywords: cleft lip and palate, development, behaviour, emotional, social, treatment, quality of life

Word count: approximately 12,597

Running title: Psychological adjustment to CL/P: A narrative review 


\section{Introduction}

A cleft of the lip and/or the palate (CL/P) is one of the most common congenital conditions found in humans. Although the prevalence rate of CL/P varies substantially across different geographical areas and ethnic groups, it occurs in approximately one in every 500-700 births per year globally (World Health Organization, 2012). Although the most visible features of the cleft are normally repaired during the child's first year of life, facial scarring, functional difficulties and/or speech problems may remain. Throughout childhood, individuals born with $\mathrm{CL} / \mathrm{P}$ will thus engage in a multidisciplinary treatment pathway, including plastic and maxillofacial surgery, otorhinolaryngology, orthodontics, speech and language therapy and psychology.

CL/P and its treatment can pose many challenges for those affected and their families, impacting upon several areas of psychological and social functioning. For individuals born with CL/P, ongoing treatment and medical appointments may represent a significant burden, in addition to the comments, questions, staring and teasing which may accompany a visible and/or audible difference (Rumsey \& Harcourt, 2005). Previous research has thus highlighted potential difficulties for those born with $\mathrm{CL} / \mathrm{P}$ in relation to social, emotional, cognitive and behavioural functioning (see Hunt, Burden, Hepper \& Johnston, 2005 for the most comprehensive recent review). Tentative evidence for the impact of a number of interposing variables on individual adjustment, such as age, cleft type, gender, ethnicity, socio-economic status and the presence of other conditions additional to the cleft has also been presented (Hunt et al., 2005). Unfortunately, findings are contradictory and most existing reviews report significant methodological limitations which prevent firm conclusions from being drawn.

In spite of the number of review articles published during the last decade (Hunt et al., 2005; Collett \& Speltz, 2007; Yazdy, Honein, Rasmussen \& Frias, 2007; de Sousa, Devare \& Ghanshani, 2009; Richman, McCoy, Conrad \& Nopoulos, 2012; Klassen et al., 2012; Pavia \& Andre, 2012; Zeytinoglu \& Davey, 2012; Antonarakis, Patel \& Tompson, 2013; Dimberg, Arnrup \& Bondemark, 2015; Liddle, Baker, Smith \& Thompson, 2015; Queiroz Herkrath, Herkrath, Rebelo \& Vettore, 2015; Zhu, Jayaraman \& Khambay, 2015), none have offered a comprehensive update in relation to psychological adjustment to CL/P since the overview provided by Hunt et al. in 2005. Of the reviews published since 2005, the majority have made repeated reference to literature which could be considered out of date, despite the high volume 
of research which has been published more recently. Where this more recent literature has been considered, much of it has been excluded for not meeting stringent inclusion criteria, leaving only a small percentage of the total information published available for scrutiny. Given the well-known commonality of methodological challenges in this field, an inclusive approach to reviewing the literature may yield a better understanding of the work being carried out and of where the difficulties lie. In addition, several of these reviews have limited their focus to specific aspects of adjustment, such as neuropsychological, behavioural and academic functioning (Richman et al., 2012), aesthetic and psychosocial outcomes of surgical procedures (Pavia \& Andre, 2012; Liddle et al., 2015; Zhu et al., 2015), and health-related quality of life (HRQoL; Klassen et al., 2012; Antonarakis et al., 2013; Dimberg et al., 2015; Queiroz Herkrath et al., 2015). While these reviews are helpful, little consideration has been given as to how these different concepts and findings may interact and overlap. A more comprehensive picture of psychological adjustment to CL/P is necessary if we are to evaluate the current state of knowledge effectively and make advancements. Finally, it must be acknowledged that the field of CL/P has been making gradual shifts away from the traditional biomedical model and toward a more balanced, inclusive and patient-driven approach in recent years (Stock et al., manuscript in preparation). No existing review has effectively examined the literature within the context of these modern developments, or considered what this may mean for the field moving forward.

An authoritative, comprehensive, up-to-date and inclusive review of recent literature in the field of psychological adjustment to CL/P is currently lacking, and is clearly needed in light of the rapidly expanding and shifting field. The present article provides a narrative description of the literature published since the review carried out by Hunt et al. (2005), which was completed in December 2003.

\section{Research Aims}

1) To summarise the literature published between January 2004 and July 2015 according to five key domains of psychological adjustment, as well as overall reports of psychological wellbeing and quality of life (QoL)

2) To investigate the impact of contributing variables and potential associations between domains of adjustment

3) To assess the progress made toward advancing knowledge in this field during the last decade and to discuss future directions. 


\section{Method}

\section{Inclusion Criteria}

All original, peer-reviewed articles pertaining to the psychological adjustment of individuals affected by CL/P published between January 2004 and July 2015 were included.

Quantitative, qualitative and mixed-methods papers were all considered. No age restrictions of the participants were imposed. Articles relating to all types of syndromic and nonsyndromic CL/P were included. All methods of measurement, including self-reports, parentreports and third-party reports (such as those obtained via clinicians, laypersons and teachers) were included. Articles published online while 'in press' were also included where available. Articles published in all languages were included where English transtations could be obtained.

\section{Exclusion Criteria}

Case studies and unpublished dissertations were excluded. Articles relating to "visible difference', 'disfigurement', 'craniofacial conditions' or similar search terms were excluded where results were not separated according to condition. No literature reviews, systematic reviews, summary articles, book chapters or meta-analyses published during the search period were included, but were stored separately for reference. Articles relating only to the psychological adjustment of parents or other family members with CL/P were excluded, since this subject has been covered extensively in a previous review by Nelson and colleagues (2012). Articles regarding 'late presentation' for cleft repair in children, young people and adults were excluded since the findings were not comparable to routine treatment.

\section{Search Strategy}

The PsycInfo, MEDLINE, Science Direct, Web of Science and CINAHL databases were examined using similar but extended search terms to those detailed in the review conducted by Hunt et al. in 2005 (see Table 1 for a full list) [Table 1 near here]. The reference lists of included articles and previous reviews were checked to reduce the likelihood of any abstracts being missed. The literature search was performed by the first author between November 2014 and January 2015, and was updated again at the end of July 2015. Details of included and excluded articles are provided in Figure 1 [Figure 1 near here]. To assess quality control, the second author was given 15 randomly selected abstracts to review. The 
evaluations made by the first and second authors were subsequently compared, and agreement was found to be high. Minor discrepancies were discussed until full agreement was reached.

\section{Domains of Adjustment}

In the context of this literature review, 'adjustment' was conceptualised as the process of the relative adaptation of an individual to the demands of their environmental context (see Seaton, 2009). The findings of each article were categorised according to five key domains of adjustment: Developmental Trajectory; Behaviour; Emotional Wellbeing; Social Experiences; and Satisfaction with Appearance and Treatment. In the absence of conventionally agreed domains of adjustment, the development of each domain was guided by recent literature (e.g. Feragen et al., 2015; Stock, Hammond, et al., in press) and designed to build upon and refine the categories used in the review by Hunt et al. (2005). Decisions regarding the definition and content of each domain was discussed and reflected upon by the authors throughout the review process. Table 2 describes the categorisation of findings into these key domains [Table 2 near here].

\section{Results \\ Included Articles}

In total, 148 articles were included in this narrative review. Of these articles, 128 were quantitative in nature. Sixteen studies used a qualitative approach, while four studies used a combination of both quantitative and qualitative measures. An overview of each article is described in more detail in Table 3 [Table 3 near here].

\section{Summary of Findings across Key Domains of Adjustment}

Initially, the findings pertaining to each domain are described in relation to how individuals with CL/P fare when likened to various comparison groups. Contributing variables, such as age, gender and cleft type are also described. Where appropriate, a description of associations across the different domains is presented. Finally, findings relating to overall psychological wellbeing or quality of life are summarised.

\section{Developmental Trajectory}

\section{General Health}


Aspects of general physical health were thought to impact upon psychological functioning. Individuals with $\mathrm{CL} / \mathrm{P}$ were deemed to be in poorer general health in relation to comparison groups in two studies (Damiano et al., 2006; Knight, Cassell, Meyer \& Strauss, 2015). According to one study, children with cleft palate only (CPO) were most likely to be defined as having special health care needs (Damiano et al., 2006). However, Eide, Skjærven, Irgens, Bjerkedal and Øyen (2006) did not find disability or mortality to be raised in those born with a cleft.

Physical characteristics, such as height (Nopoulos, Langbehn, Canady, Magnotta \& Richman, 2007) were thought to be affected by CL/P, particularly in the case of CPO (Persson, Becker \& Svensson, 2007). Weight was also found to be lower among individuals with CL/P (Persson et al., 2007; Smith, Walker, Badawi, Waters \& MacLean, 2014), which was believed to be influenced in part by the number of respiratory events (Smith et al., 2014). Those with $\mathrm{CPO}$ were shown to have weaker muscular strength when compared to the reference group (Persson et al., 2007). Studies of sleep patterns in children with CL/P suggested no differences in one case (Brand et al., 2009) and an association with cognitive functioning in another (Smith et al., 2014).

\section{Associated Conditions}

A study by Bashir, Hodgkinson, Montgomery \& Splitt (2008) reported a high percentage of 22Q11 diagnoses, predominantly among those with submucous cleft palate (smCP), and called for routine screening to be implemented. Burnell and colleagues (2014) found $16 \%$ of their sample to have a confirmed or strongly suspected syndromic condition, developmental disorder or further major malformation in addition to the cleft. Another $12.3 \%$ had mild developmental delay, while $3.7 \%$ had received a diagnosis of autism. According to Chetpakdeechit, Mohlin, Persson and Hagberg (2010), 25\% of their sample had a diagnosed syndrome, $15.2 \%$ had Pierre Robin Sequence and 18\% had an intellectual disability, the frequencies of which were influenced by the length of the cleft palate. In two studies of 10year-old children, between $30-40 \%$ had a syndrome and/or a condition in addition to the cleft thought to impact on psychological adjustment, learning, development and/or cognition (Feragen \& Stock, 2014; Feragen, Stock \& Rumsey, 2014). Chetpakdeechit and colleagues (2010) also reported a number of affected organ systems. One study reported that children with $\mathrm{CL} / \mathrm{P}$ were significantly more likely to have a developmental delay than the control group (Knight et al., 2015). Developmental difficulties seemed to be more prevalent among 
types of cleft involving the palate (Chetpakdeechit et al., 2010; Burnell et al., 2014; Feragen et al., 2014).

\section{Neurological Aspects}

Neurological abnormalities were found among individuals with CL/P in a number of studies. Compared to controls, significant abnormalities and decreased volume and surface areas of the cerebrum and cerebellum were found in patients born with a cleft (Nopoulos et al., 2005; Boes et al., 2007; Nopoulos et al., 2007). The structure of the superior temporal plane was found to be disproportionately large (Shriver, Canady, Richman, Andreasen \& Nopoulos, 2006) and abnormalities in the function of the distributed neural circuitry were also detected among adult men with CL/P compared to controls (Goldsberry, O'Leary, Hichwa \& Nopoulos, 2006). According to Conrad, Canady, Richman and Nopoulos (2008), children with CL/P scored higher on tests of neurological soft signs, indicating non-specific cerebral dysfunction, particularly in younger participants (age range 7-17 years). Tissue distribution of cortical grey and white matter within the cerebrum were found to be abnormal in males, but were proportional to controls among girls with CL/P(Nopoulos et al., 2007). Among boys, right-sided clefts were associated with more abnormalities in brain structure, particularly in regard to reduced white matter volume (van der Plas, Conrad, Canady, Richman \& Nopoulos, 2010). In another study, children with CL/P exhibited abnormally large cerebral cortex grey matter volumes, with decreased volumes of subcortical grey matter and cerebral white matter structures (Adamson, Anderson, Nopoulos, Seal \& de Costa, 2014). However, no gender effects were found in this study.

Neurological abnormalities were related to lower scores on measures of intelligence (IQ; Shriver et al., 2006, Nopoulos et al., 2010), language (Goldsberry et al., 2006; Shriver et al., 2006) and reading (Goldsberry et al., 2006), as well as a generally impaired developmental trajectory (Nopoulos et al., 2007).

\section{Cognitive Development and Language}

One study suggested that individuals with CL/P have significantly lower general IQ than comparison groups (Hentges et al., 2011), while six studies found those with CL/P to score in line with comparison groups and/or within the normal range (Eide et al., 2006; Nopoulos et al., 2010; Conrad, McCoy, deVolder, Richman, \& Nopoulos, 2014; Petrackova et al., 2015; Feragen \& Stock, in press), except in the case of CPO (Persson, Becker \& Svensson, 2008). 
Individuals with CL/P demonstrated difficulties on tests of vocabulary (Scherer, Williams \& Proctor-Williams, 2008; Young, Purcell \& Ballard, 2010), grammar (Young et al., 2010), verbal IQ (Hentges et al., 2011; Conrad, Richman, Nopoulos \& Dailey, 2009; Conrad et al., 2014), phonological awareness (Scheuerle, Guilford \& Habal, 2004; Lee, Young, Liow \& Purcell, 2015), narrative retelling (Klinto, Salameh \& Lohmander, 2015) and receptive and expressive language (Scheuerle et al., 2004; Laasonen et al., 2004; Smith et al., 2014). Varying degrees of dyspraxia/apraxia of oral motor mechanisms were also identified in one study (Laasonen et al., 2004). In addition, difficulties were identified in relation to performance IQ (Hentges et al., 2011), comprehension (Hentges et al., 2011), spelling (Hentges et al., 2011; Lee et al., 2015), visual memory (Richman, Wilgenbusch \& Hall, 2005) and mathematics (Hentges et al., 2011; Wehby, Collett, Barron, Romitti, Ansley \& Speltz, 2014). However, these results were not always replicated (Conrad et al., 2009; Collett, Leroux \& Speltz, 2010; Young et al., 2012; Smith et al., 2014; Lee et al., 2015; Feragen, Særvold, Aukner \& Stock, in press).

Potential problems with reading were reported in some studies (Collett, Stott-Miller, KappSimon, Cunningham \& Speltz, 2010), while not in others (Hentges et al., 2011; Feragen, Særvold et al., in press). According to one study, case versus control group differences on tests of reading were more apparent in those reporting higher socioeconomic status and among 'older' participants (age range 7-26 years; Conrad et al., 2014). Reading was also significantly associated with language skills (Feragen, Særvold et al., in press), verbal fluency, auditory memory (Conrad et al., 2014) and visual memory (Richman et al., 2005; Conrad et al., 2014). In one study, hearing did not affect reading test scores (Conrad et al., 2014), while differences in reading were reduced slightly when hearing problems were accounted for in another case (Collett, Stott-Miller et al., 2010).

In two studies, language development (Collett, Leroux et al., 2010) and babbling complexity (Scherer et al., 2008) of infants with CL/P was found to be significantly poorer than controls by the age of 12 months. Language development was not found to be affected by cleft type, articulation or hearing difficulties (Young et al., 2010). Three studies found individuals with CPO to have lower levels of cognitive functioning than the reference group (Laasonen et al., 2004; Persson et al., 2008; Feragen \& Stock, in press). One study reported that those with more 'severe' clefts had lower performance IQ (Demir, Karacetin, Baghaki \& Aydin, 2011). In studies where syndromes and additional conditions had already been identified, cognitive function was significantly affected by the presence of these conditions (Feragen, Borge \& 
Rumsey, 2009; Collett, Stott-Miller et al., 2010; Smith et al., 2014; Feragen \& Stock, in press; Feragen, Særvold et al., in press).

Cognition scores were higher at 18 months of age in children whose mothers were more sensitive toward their infant, showed high rates of positive involvement and who looked at their infant more often (Murray et al., 2008). Further, verbal IQ at age seven years was mediated by maternal sensitivity at two months of age (Hentges et al., 2011). Mother-infant interaction, as well as demographic factors and early measures of mental and psychomotor development, were predictors of language outcomes at ages five and seven years (Collett, Leroux \& Speltz, 2010).

\section{Educational Experiences}

Two studies reported individuals with CL/P to have lower educational achievement than their peers without CL/P (Wehby, Collett et al., 2014; Knight et al., 2015) and elevated rates of academic difficulties (Snyder \& Pope, 2010), particularly in the ease of CPO (Persson, Becker $\&$ Svensson, 2012). In contrast, three studies found no significant differences in educational achievement between those with and without CL/P (Cheung, Loh \& Ho, 2007; van der Plas et al., 2013; Collett et al., 2014). According to five studies, young people with CL/P were more likely to be engaged in special educational services (Damiano et al., 2006; Collett, Leroux et al., 2010; Hentges et al., 2011; Wehby, Collett et al., 2014) and to repeat a grade (LorotMarchand et al., 2015) than their peers who were born without a cleft. This finding was particularly pronounced for those with palatal involvement (Damiano et al., 2006; Collett, Leroux et al., 2010; Collett et al., 2014; Wehby, Collett et al., 2014) and hearing difficulties (Tierney et al., 2015). In one sample of children with CL/P, 7\% were placed in 'gifted' classes (Scheuerle et al., 2004).

Hearing difficulties, ear infections and OME were perceived to have a negative impact on learning at school in two qualitative studies (Tierney et al., 2015; Stock, Feragen \& Rumsey, in press). The negative impact of children with CL/P missing more school than their classmates was also highlighted in three other studies (Chimruang et al., 2011; Knight et al., 2015; Lorot-Marchand et al., 2015). School performance was influenced by perceptions of general health in one study (Bos and Prahl, 2011). In one qualitative study, a possible lack of understanding and support from teachers was also highlighted (Stock, Feragen, et al., in press). 
Young people with CL/P scored lower than comparison groups on self-perceptions of 'general school' (Aravena, Gonzalez, Oyarzun, Coronado, in press), math and verbal ability (Gussy \& Kilpatrick, 2006). However, five studies found no differences in relation to self-reports of overall scholastic competence among children with CL/P and comparison groups (Gussy \& Kilpatrick, 2006; Oosterkamp et al., 2007; Gkantidis, Papamanou, Karamolegkou \& Dorotheou, in press; Stock, Feragen \& Rumsey, 2015), specifically in regard to females (Feragen, Stock \& Kvalem, 2015). Boys were found to have higher ratings of scholastic competence than the reference group in one study (Feragen et al., 2015). In one qualitative study, participants reported having to work harder than their peers to demonstrate their capability (Stock, Feragen, et al., 2015). Perceptions of school were lower among minority ethnic groups (Broder, Wilson-Genderson \& Sischo, 2012) and among adolescents with an additional condition (Feragen et al., 2015).

\section{Employment}

Three studies identified potential problems with stigma within the workplace (Chan, McPherson \& Whitehill, 2006; Lorot-Marchand et al., 2015; Stock et al., 2015). However, adults generally believed that having CL/P had little or no influence over applying for a job (Oosterkamp et al., 2007) or their achievements at work (Oosterkamp et al., 2007; Stock et al., 2015). According to one qualitative study, some participants felt that having a visible difference had helped them to stand out within the workplace in a beneficial way (Stock et al., 2015).

\section{Behaviour}

\section{Conduct Problems}

In relation to comparison groups, individuals with $\mathrm{CL} / \mathrm{P}$ reported higher levels of behavioural problems according to one study (Ha et al., 2013). No norms were available in one other study, but $38-44 \%$ of parents scored their child above the clinical cut-off in relation to behavioural conduct (Millar et al., 2013). However, Berger and Dalton (2009) found adolescents with CL/P to report fewer conduct problems than their peers without CL/P. In three other studies, no significant differences were found between individuals with CL/P and controls on measures of conduct problems (Murray et al., 2008; Brand et al., 2009; Collett, Cloonan, Speltz, Anderka \& Werler, 2012). 
One study found more behavioural problems in boys with CL/P compared to girls with CL/P at age 10 (Collet et al., 2012). However, when compared to a reference group, girls had similar conduct scores to the reference group, when boys had fewer conduct problems than the reference group (Feragen \& Stock, in press). No differences in behavioural scores were found according to cleft type (Millar et al., 2013), while children with an additional condition reported significantly more conduct problems than children with a cleft only at age 10 (Feragen \& Stock, 2014; Feragen \& Stock, in press).

Behavioural problems were more likely if there was a history of CL/P in the family, if the child had been teased, or if the child had a visible scar (Hunt et al., 2007). Behavioural problems, inattention/hyperactivity and somatic symptoms were also associated with lower socioeconomic status (Wehby et al., 2012).

\section{Internalising and Externalising Behaviours}

Children were perceived to have higher levels of internalising behavioural problems according to parent (Hunt, Burden, Hepper, Stevenson \& Johnston, 2007) and teacher (Murray et al., 2010) reports, and higher levels of externalising behavioural problems according to parent reports (Hunt et al., 2007). Males were more likely to score in the clinical range for aggressive behaviour than females, while females were more likely to score in the clinical range for anxious-depressed behaviours (Ha et al., 2013). Aggressive/oppositional behaviour was in line with normative samples in another study (Wehby et al., 2012). Feragen and Stock (in press) reported 10-year-olds with a cleft and an additional condition to have higher levels of withdrawal than in cases of a cleft only.

\section{Inattention/Hyperactivity}

No overall significant differences in measures of hyperactivity between those with CL/P and comparison groups were found in two studies (Brand et al., 2009; Feragen \& Stock, in press), while the group with $\mathrm{CL} / \mathrm{P}$ showed elevated rates of attention problems compared to norms in two other studies (Snyder and Pope, 2010; Conrad et al., 2014). In one study, as many as $18 \%$ of the sample had received a diagnosis of Attention Deficit and/or Hyperactivity Disorder (AD/HD; Richman, Ryan, Wilgenbusch \& Millard, 2004), suggesting that AD/HD may be over-diagnosed in children with CL/P (Richman et al., 2004; Tierney et al., 2015). In contrast, three studies found similar or fewer problems with attention and hyperactivity in young people with a cleft compared to the reference group (Berger \& Dalton, 2009; Wehby et 
al., 2012; Feragen et al., 2015), and similar prevalence rates as in the general population (Feragen et al., 2014).

Two studies reported significantly higher scores of hyperactivity, impulsivity and inattention in males with CL/P than controls (Nopoulos et al., 2010; Ha et al., 2013), while another study found fewer hyperactivity/attention problems in boys compared to a reference group at age 10 (Feragen \& Stock, in press) and 16 (Feragen et al., 2015). In one study, hyperactivity was found to be higher in children with CLP compared to those with CPO (Feragen \& Stock, in press). Children with an additional condition reported significantly more attention problems than children with a cleft only at age 10 and at 16 years of age (Feragen \& Stock, 2014; Feragen \& Stock, in press; Feragen et al., 2015), a finding that was strongest in girls. However, levels of behavioural problems were still within the normal range.

\section{Emotional Wellbeing}

\section{Psychiatric Conditions}

Gourion and colleagues (2004) found a high incidence of CPO in patients with schizophrenia (30\%) and their parents (24\%). Major Depressive Disorder was also found to be significantly more prevalent in individuals with CL/P than in controls (Demir et al., 2011). The prevalence of psychiatric morbidity was $28.5 \%$ among patients with CL/P in one study, which was found to be significantly higher than the control group (Yunusa \& Obembe, 2013). However, the rate of psychiatric diagnoses was not found to differ significantly from the general population in another study (Shriver et al., 2006). Psychopathology was related to lower performance IQ according to one study (Demir et al., 2011).

\section{Emotional Functioning}

A number of studies found individuals with CL/P to report poorer emotional functioning and more depressive symptoms than norms (Sinko et al., 2005; Hunt, Burden, Hepper, Stevenson \&Johnston, 2006; Hunt et al., 2007; Mani, Carlsson \& Marcusson, 2010), and more anxiety (Hunt et al., 2007) and somatic symptoms (Wehby et al., 2012). Twenty-four percent of 4-9year-old children met the screening criteria for Separation Anxiety Disorder (SAD) according to parent reports in one study (Tyler, Wehby, Robbins \& Damiano, 2013). SAD was found to be more common in non-Caucasian participants, and was related to lower parental education, poorer parental and child health status, children's problems with feeding and speech and lower satisfaction with facial appearance (Tyler et al., 2013). Other studies found individuals 
with CL/P to report levels of emotional problems which were in line with (Gussy \& Kilpatrick, 2006; Hunt et al., 2006; Oosterkamp et al., 2007; Brand et al., 2009; Wehby et al., 2012; Feragen \& Stock, 2014; Gassling, Kessler et al., 2014; Lima et al., 2015), or lower than (Cheung, Loh \& Ho, 2006; Munz, Edwards \& Inglehart, 2011; Millar et al., 2013; Feragen et al., 2015) comparison groups. Two studies reported few children to score within the clinical range for depression at age 10 (Millar et al., 2013; Feragen \& Stock, in press). Within one qualitative account, only a minority of participants attributed ongoing emotional difficulties to their CL/P (Stock et al., 2015).

In some cases, males with CL/P reported less emotional problems than females with CL/P (Eslami, Majidi, Aliakbarian \& Hasanzadeh, 2013; Feragen \& Stock, in press; Feragen et al., 2015), while the opposite was true according to two studies (Mani et al., 2010; Millar et al., 2013). Girls were more likely to report psychosomatic complaints within the clinical range (Ha et al., 2013). At age 10, girls with a visible cleft had fewer emotional difficulties than girls with a non-visible cleft according to parent reports, while the opposite was true for the boys (Feragen \& Stock, in press). In contrast, males with a visible cleft reported significantly less depressive symptoms at age 16 than the comparison group in one study (Feragen, Kvalem, Rumsey \& Borge, 2010). At age 16, girls reported more emotional difficulties than the reference group, while boys reported fewer emotional difficulties compared to the reference group (Feragen et al., 2015). According to one study on adults, patients aged between 20 and 32 years of age were most negatively affected by emotional problems (Mani et al., 2010). A second study indicated that patients aged between 14-19 years had poorer emotional wellbeing than those aged 7-13 years (Broder et al., 2012). According to Bos and Prahl (2011), children aged between eight and 12 had more emotional symptoms than those aged 13-15 years. In contrast, no differences were found in rates of depression or anxiety according to cleft type (Eslami et al., 2013; Millar et al., 2013), age (Eslami et al., 2013; Lima et al., 2015), gender or education (Lima et al., 2015). Lower emotional wellbeing scores were found among minority ethnic groups when compared to their White or Asian peers (Broder et al., 2012), and among children with an additional condition at age 10 (Feragen \& Stock, 2014; Feragen \& Stock, in press) and at age 16 according to parent reports (Feragen et al., 2015).

Several studies reported associations between emotional distress and other factors, including perceptions of general health (Bos \& Prahl, 2011), having a surgical recommendation, lower perceptions of school experiences (Broder et al., 2012; Broder, Wilson-Genderson, Sischo \& 
Norman, 2014), lower language and reading skills (Feragen, Særvold et al., in press) and overall HRQoL (Broder, Wilson-Genderson \& Sischo, 2014).

\section{Self-Concept}

Self-concept scores were in line with norms and demonstrated no significant differences between individuals with CL/P and the control group according to one study (Boes et al., 2007). In another three studies, children with CL/P scored higher in relation to perceptions of self-image and/or physical ability than controls (Gussy \& Kilpatrick, 2006; Pisula, Lukowska \& Fudalej, 2014; Aravena et al., in press). However, one study found younger participants to have lower self-concept scores (Mani et al., 2010), while a qualitative study described young people as struggling with their self-image (Tiemens, Nicholas \& Forrest, 2013).

Males scored lower than controls on ratings of personal power, while females scored higher than controls on measures of self-control (Pisula et al., 2014). A negative correlation between self-concept and mastery, and a positive association between depressive symptoms and mastery, were found in one study (Broder, Wilson-Genderson \& Sischo, 2014). Another study asked children to draw themselves; all participants drew themselves with 'normal' mouths (Abd-Elsayed, Delgado \& Livingstone, 2013).

\section{Self-Esteem}

In a study by Noor and Musa (2007), the majority of patients and their parents stated that selfconfidence had been affected or "very much affected" by the cleft. Lower levels of selfesteem were also found among adults with CL/P (Cheung et al., 2007) and children with CL/P (Kramer, Gruber, Fialka, Sinikovic, \& Schliephake, 2008) in relation to comparison groups. In contrast, self-esteem was found to be significantly higher in children with CL/P compared to their peers in two studies (Sagheri, Ravens-Sieberer, Braumann \& von Mackensen, 2009; Millar et al., 2013). According to a number of studies, self-confidence could still be affected in adulthood (Havstam, Laakso, Lohmander \& Ringsberg, 2011a; Hamlet \& Harcourt, 2015; Stock et al., 2015). No effect of cleft type on self-esteem was found in one study (Millar et al., 2013).

Several studies reported associations between self-esteem and other psychological factors, such as coping styles (Pisula et al., 2014), recognition from peers (Chetpakdeechit, Hallberg, Hagberg \& Mohlin, 2009), less social anxiety and emotional distress (Cheung et al., 2007), 
greater level of behavioural problems as perceived by the parents (Millar et al., 2013), and successful employment (Stock et al., 2015).

\section{Social Experiences}

\section{Parent-Child Relationships}

Mothers were found to be less sensitive toward their infant at the age of two months (Murray et al., 2008) and more disengaged (Despars et al., 2011; Montirosso et al., 2012) when compared to controls. Correspondingly, children with CL/P were found to be less engaged and to give fewer communicative signals (Frederickson, Chapman \& Hardin-Jones, 2006; Montirosso et al., 2012). However, no differences were found between those born with CL/P and control groups in relation to the quality of attachment by 18 months of age in another (Murray et al., 2008). Children with insecure attachment were more likely to have problems with anxiety and depression than those who were secure, which was also evident in the control group (Murray et al., 2010). Maternal adjustment (Berger \& Dalton, 2011; Despars et al., 2011) and a generally poorer parenting environment (Murray et al., 2010; Tyler et al., 2013; Stock, Feragen et al., in press) were believed to exacerbate difficulties with social relationships in later life.

Two studies suggested an effect of cleft type on the development of parent-child relationships. For children with a cleft lip, a significant association between maternal signs of depression and infant temperament was identified (Montirosso et al., 2012), while mothers of children born with more 'severe' types of cleft were less positively involved with their infant and looked at them less (Murray, 2008). However, the 'severity' of the cleft had no impact on attachment representations in another study (Despars et al., 2011). Having an antenatal diagnosis of CL/P was not related to mother-infant interaction at two months of age (Murray et al., 2008).

In contrast to these findings, other studies found mothers of children with CL/P to be more encouraging and to support their children more often than mothers of healthy children and those with other health conditions (Gassling, Christoph et al., 2014). Similarly, children with $\mathrm{CL} / \mathrm{P}$ were found to demonstrate more autonomous behaviour and to interrupt their parent less frequently (Gassling, Christoph et al., 2014). According to self-reports, individuals with CL/P described normal or particularly close relationships with family members (Cheung et al., 2006; Gussy \& Kilpatrick, 2006; Oosterkamp et al., 2007; Chimruang et al., 2011; Crerand et al., 2015; Gkantidis et al., in press), which was believed to act as a buffer against 
social challenges (Hall, Gibson, James \& Rodd, 2013; Tiemens et al., 2013; Stock, Feragen et al., in press). Nonetheless, two studies reported CL/P to have a negative impact on family life (Kramer et al., 2009; Gkantidis et al., in press). Ethnicity was also associated with greater family cohesion in one study (Crerand et al., 2015).

\section{Social Functioning}

Children with CL/P have been rated as being less socially motivated (van der Plas et al., 2013), less socially competent and as having poorer overall social functioning than their peers without CL/P (Slifer et al., 2004; Sinko et al., 2005; Frederickson et al., 2006; Boes et al., 2007; Kramer et al., 2009; Ha et al., 2013). In contrast, several studies found little or no influence of CL/P on social competence and functioning (Oosterkamp et al., 2007; Berger \& Dalton, 2009; Munz et al., 2011; Collett et al., 2012; Gassling, Kessler, et al., 2014; Stock, Feragen, et al., 2015; Gkantidis et al., in press). In four studies, indixiduals with CL/P reported a fear of negative evaluation by others, anxiety or self-consciousness in social situations, and social withdrawal (Berger \& Dalton, 2009; Murray et al., 2010; Chimruang et al., 2011; Demir et al., 2011; Stock et al., 2015). Higher levels of social avoidance and anxiety were found in adults with CL/P when compared to adolescents with CL/P and a control group in one study (Cheung et al., 2007). However, this finding was not replicated by van der Plas and colleagues (2013). Social Anxiety Disorder was found to be significantly more prevalent in individuals with CL/P than in controls in one study (Demir et al., 2011). In parallel, social anxiety was associated with poorer academic performance (van der Plas et al., 2013 ) and poorer social experiences based on self-reports (Berger \& Dalton, 2009; Berger \& Dalton, 2011). In contrast, a possible protective effect of close friendships was found in two studies (Berger \& Dalton, 2009; Feragen et al., 2010), while the benefits of meeting another person with CL/P was discussed in three qualitative studies (Hamlet \& Harcourt; Stock et al., 2015; Stock, Feragen et al., in press). Being socially competent was seen by patients as an important factor in overcoming social barriers in one qualitative study (Stock, Feragen et al., in press), while social withdrawal was related to poorer social experiences based on selfreports (Berger \& Dalton, 2009; Berger \& Dalton, 2011).

In two studies, social functioning was found to be associated with neurological abnormalities (Nopoulos et al., 2005; Boes et al., 2007). Two studies found the impact of CL/P on social functioning to decrease with age (Mani et al., 2010, age range 20-47 years; Gkantidis et al., in press, age range 9-33 years). Males with $\mathrm{CL} / \mathrm{P}$ have been reported to have significantly 
poorer peer relationships and social competency compared to norms (Boes et al., 2007; van der Plas et al., 2013; Feragen et al., 2015) and to be more likely to blame others as a coping strategy (Berger \& Dalton, 2009). Females with CL/P were more likely to score within the clinical range for social problems (Ha et al., 2013), and females with a visible cleft provided slightly higher reports of peer problems than females with a non-visible cleft at age 16 (Feragen et al., 2015). However, reports of peer problems were still within the normal range for females with CL/P at both age 10 and 16 (Feragen \& Stock; Feragen et al., 2015), while 16-year-old males with a visible cleft reported more positive perceptions of close friendships when compared to a reference group and when compared to those with a non-visible cleft (Feragen et al., 2015). Children with additional conditions reported more peer problems at age 10 compared to a reference group and when compared to children with a cleft only (Feragen \& Stock, 2014; Feragen \& Stock, in press). There was also a higher frequency of adolescents with additional conditions in the high risk group for social difficulties at age 16 (Feragen \& Stock, in press).

\section{Communication Difficulties}

Articulation difficulties (Ruiter, Korsten-Meijer \& Goorhuis-Brouwer, 2009) and hypernasality (Watterson, Macini, Brancamp \& Lewis, 2013) were still present among school-aged children with CL/P, particularly in those with BCLP (Ruiter et al., 2009). Difficulties with being misunderstood created frustration and embarrassment in social situations (Damiano et al., 2006, Berger \& Dalton, 2009; Berger \& Dalton, 2011), and a more negative communication attitude (Havstam, Sandberg \& Lohmander, 2011). Young people judged to be hypernasal were deemed to be less likely to make friends easily, less likely to fit in with friends and more likely to be teased (Watterson et al., 2013). Concurrently, speech problems, satisfaction with speech and/or reading difficulties were associated with social difficulties and general adjustment in a number of cases (Frederickson et al., 2006; Damiano et al.,2007; Murray et al., 2010; Berger \& Dalton, 2011; Demir et al., 2011; Feragen, Særvold et al., in press; Gkantidis et al., in press). Forming an assessment of one's own speech, learning about one's communication and taking responsibility for communication were identified as important factors in coping with speech difficulties (Havstam, Laakson \& Ringsberg, 2011). Hearing difficulties were also found to impair social functioning and to leave children feeling isolated (Tierney et al., 2015; Stock, Feragen et al., in press). 
One study conducted in China found a general cultural bias in terms of a less favourable attitude towards disabled persons (Chan et al., 2006). When presented with a series of photographs of patients with CL/P, laypersons reported a high level of social distance (Pausch et al., in press). However, compared to results obtained 30 years earlier in a similar study, societal perceptions of patients with CL/P were believed to have improved (Pausch et al., in press). In a qualitative study, Hamlet and Harcourt (2015) found that older adults believed societal attitudes to appearance had changed, but not necessarily for the better. In one qualitative study, public perceptions of CL/P were found to have an impact on psychological adjustment (Stock, Feragen et al., in press). Three eye-tracking studies found that laypersons are more often fixated on the mouths of patients with CL/P and spend longer looking at the areas of the face affected by CL/P (Meyer-Marcotty, Gerdes, Reuther, Stellzig-Eisenhauer \& Alpers, 2010; Meyer-Marcotty, Gerdes, Stellzig-Eisenhauer \& Alpers, 2011, van Schijndel, Litschel, Maal, Berge \& Tasman, in press). However, this was not related to laypersons' ratings of negative personality traits (van Schijndel et al., in press).

\section{Reports of Teasing}

Included studies showed wide variations in the reported frequency of teasing among patients with CL/P as rated by patients and parents, ranging from $20 \%$ to $75 \%$ (Semb et al., 2005; Hunt et al., 2006; Hunt et al., 2007; Noor \& Musa, 2007; Feragen et al., 2009; Feragen \& Borge, 2010; van Lierde et al., 2012; Lorot-Marchand et al., 2015; Feragen, Særvold et al., in press). Nineteen out of 20 participants reported that they had been teased about appearance or speech in another study (Demir et al., 2011). In a minority of cases, patients reported having been physically hurt (Hunt et al., 2006). Perceived teasing was reported to be higher among patients with CL/P than among controls (Hunt et al., 2006; Hunt et al., 2007; Demir et al., 2011; van Lierde et al., 2012). In one qualitative study, the majority of patients reported being teased at some point, although their perceptions of the severity and consequences of teasing varied considerably (Stock, Feragen et al., in press). This finding was supported by one quantitative study, which found that not everyone who reported teasing confirmed that the teasing worried them (Noor \& Musa, 2007).

Teasing was predominantly related to appearance (lip, nose, teeth) or speech (Semb et al., 2005; Hunt et al., 2006; Hunt et al., 2007; Noor \& Musa, 2007; Berger \& Dalton, 2009; Demir et al., 2011; van Lierde et al., 2012; Lorot-Marchand et al., 2015). In one qualitative study (Tiemens et al., 2013), participants reported that their cleft lip had made them feel more 
shy and less confident. The use of social withdrawal and distraction as coping strategies were related to poorer social experiences and subsequently to poorer adjustment (Berger \& Dalton, 2011). Teasing was reported to occur at school in most cases (van Lierde et al., 2012; LorotMarchand et al., 2015), although two studies also reported perceived discrimination to also occur in the workplace (Lorot-Marchand et al., 2015; Stock et al., 2015). In a study by Semb and colleagues (2005), the majority of teasing was found to occur between the ages of 8-11 years, followed by 12-15-year-olds, with very little teasing occurring before or after this. However, Noor and Musa (2007) reported teasing to occur as early as two years of age, which persisted for a minority of individuals with CL/P until the age of 17 years. The highest onset of teasing in this study was seven years of age (Noor \& Musa, 2007). Two studies reported high levels of teasing during adolescence (Berger \& Dalton, 2009; Lorot-Marchand et al., 2015).

Several studies reported associations between teasing and other psychological factors. A history of teasing/bullying was a significant predictor of psychological difficulties and internalising/externalising behaviour problems, more so than having CL/P per se (Hunt et al., 2006). Further, peer harassment was related to appearance dissatisfaction at ages 10 and 16 (Feragen \& Borge, 2010). Another study showed an association between the visibility of the cleft and appearance satisfaction that was fully mediated by reported peer harassment (Feragen \& Borge, 2010). However, one study found no differences between those who reported taunting and those who did not in relation to satisfaction with appearance (LorotMarchand et al., 2015). Teasing oyer appearance, but not speech, was significantly related to depressive symptoms in two studies (Demir et al., 2011; Lorot-Marchand et al., 2015), while teasing was correlated with poorer language and reading skills in another (Feragen, Særvold et al., in press). In contrast, absence of perceived teasing was associated with evidence of psychosocial resilience in one study (Feragen et al., 2009).

\section{Social Acceptance}

Individuals born with CL/P reported not being aware of their difference until late childhood (Chetpakdeechit et al., 2009). How they were treated by others played a key role subsequently in shaping their own perceptions of their cleft (Havstam, Laakso \& Ringsberg, 2011). Perceived stigma or unwanted interest from others, including staring, comments and questions, was reported by parents and patients in a number of studies (Berger \& Dalton, 2009; Chetpakdeechit et al., 2009; Feragen et al., 2009; Alansari, Bedos \& Allison, 2014; 
Tiemens et al., 2013; Stock \& Rumsey, 2015). Individuals with CL/P believed these experiences to have made them more vulnerable to feeling different from their peers (Chetpakdeechit et al., 2009; Havstam, Laakso \& Ringsberg, 2011; Alansari et al., 2014; Tiemens et al., 2013). In two qualitative studies, participants struggled with wanting to feel good about their difference and to not care about what others thought, despite wanting to feel normal and to be accepted (Havstam, Laakso \& Ringsberg, 2011; Tiemens et al., 2013). Teasing (Havstam, Laakso \& Ringsberg, 2011) and problems with nasality (Watterson et al., 2013) posed a threat to feelings of normality and ratings of social acceptance. Some individuals with CL/P reported that they lacked recognition (Chetpakdeechit et al., 2009) and felt devalued by others (Tiemens et al., 2013). In turn, low levels of perceived social acceptance were found to be associated with gaze avoidance and less assertive social patterns (Slifer et al., 2004; Slifer et al., 2006). Feelings of social isolation were reported in one study (Hamlet \& Harcourt, 2015). However, the study by Slifer and colleagues (2006) did not find any differences in social acceptance scores between individuals with CL/P and their peers without CL/P. In a qualitative study, perceptions of difference varied from "not being different" to being different in a negative or positive light (Stock, Feragen et al., in press). Similarly, some participants felt that their cleft was not very noticeable to other people, while others felt that having CL/P made them stand out, either in a negative or positive way (Stock, Feragen et al., in press).

Social acceptance scores were also be affected by gender, age and cleft visibility. Males with $\mathrm{CL} / \mathrm{P}$ reported more positive perceptions of social acceptance at age 10 when compared to a reference group (Feragen et al., 2010; Feragen \& Stock, in press), while males with a visible cleft reported more positive perceptions of social acceptance than both the reference group and those with a non-yisible cleft at age 16 (Feragen et al., 2010; Feragen et al., 2015). In a study with older adults, Hamlet and Harcourt (2015) identified a tension between not wanting to be noticed by others because of their CL/P and feeling ignored because of their older age. Other factors with the potential to impact upon social acceptance included sexual orientation and cultural factors (Stock, Feragen et al., in press).

\section{Romantic Relationships}

Compared to norms, individuals with CL/P had higher (Gussy \& Kilpatrick, 2006) or equal (Feragen et al., 2015) self-concept scores in regard to romantic relationships. In a qualitative study, many adults did not believe that CL/P had had a negative effect on their intimate 
relationships overall, while some felt it had had a positive influence (Stock et al., 2015). In this case, struggles with romantic relationships were predominantly related to young adulthood (Stock et al., 2015). In one study (Havstam, Laakso \& Ringsberg, 2011), participants had waited longer than most of their friends to have their first romantic partner, while worries about romantic relationships were based on the belief that relationships were conceptualised as confirmation of attractiveness. Males with CL/P reported more positive perceptions of romantic appeal than females with CL/P in one study, although both males and females with CL/P still reported higher perceptions of romantic appeal than norms (Feragen et al., 2015).

\section{Satisfaction with Appearance and Treatment}

\section{Patient and Parent Satisfaction with Appearance}

Eighteen studies investigated general satisfaction with appearance as reported by patients and/or their parents. In spite of a reasonable level of satisfaction being reported among patients and their parents (van Lierde et al., 2012; Wehby et al., 2012; Tyler et al., 2013), lower levels of satisfaction with facial appearance were found when compared to a control or reference group (Slifer et al., 2004; Hunt et al., 2006; Hunt et al., 2007; Chuo et al., 2008; Versnel, Duivenvoorden, Passchier \& Mathijssen, 2010; van Lierde et al., 2012; Wehby et al., 2012). The appearance of the nose, upper lip, facial profile and teeth were often cited as areas of dissatisfaction (Semb et al., 2005; Sinko et al., 2005; Hunt et al., 2006; Hunt et al., 2007; Oosterkamp et al., 2007; Chuo et al,, 2008; Berger \& Dalton, 2009; Meyer-Marcotty \& Stellzig-Eisenhauer, 2009; van Lierde et al., 2012; Nkenke, Stelzle, Vairaktaris \& Knipfer, 2013; Byrne, Chan \& O'Broin, 2014). Damiano et al. (2006) found satisfaction with appearance to be higher in patients with CL/P than in patients with clubfoot, while $57 \%$ of patients in a study by Lorot-Marchand et al. (2015) reported that they found their face beautiful. When asked about their appearance, $13 \%$ of patients in a study by Meyer-Marcotty and Stellzig-Eisenhauer (2009) indicated that 'everything was OK'. Patients reported significantly higher satisfaction with facial features not associated with CL/P (e.g. ears, eyes, hair) and with overall appearance than reference groups (Gussy \& Kilpatrick, 2006; Berger \& Dalton, 2009). This finding was also replicated in a qualitative study by Gkantidis et al. (in press).

In several studies, satisfaction with appearance was examined according to age and gender. In several cases, males were found to be more dissatisfied with appearance than females 
(Semb et al., 2005; Landsberger et al., 2006; Hunt et al., 2007; Byrne et al., 2014).

Contrastingly, the opposite was indicated in two other studies (Sinko et al., 2005; Mani, Reiser, Andlin-Sobocki, Skoog \& Holmström, 2013). Four studies found no effect of gender (Hunt et al., 2006; Oosterkamp et al., 2007; Pitak-Arnnop, Hemprich, Dhanuthai, Yildirim \& Pausch, 2011; Feragen et al., 2015). In two cross-sectional studies, satisfaction with appearance was found to decrease with age (Hunt et al., 2006, age range 8-21 years; Gkantidis et al., in press, age range 9-33 years), while one study identified this effect in female patients only (Byrne et al., 2014, age range 14-53 years). Patient ratings of appearance were found to be lowest in females aged between 24 and 30 years in one study (Sinko et al., 2005). The age of the patient did not affect satisfaction with appearance in two studies (Oosterkamp et al., 2007; Pitak-Arnnop et al., 2011). Two qualitative studies indicated that satisfaction with appearance may fluctuate over time, and continues to be an important factor during adulthood and older age (Hamlet \& Harcourt, 2015; Stock, Feragen et al., in press).

Satisfaction with appearance was found to be significantly lower in those patients with a BCLP when compared to those patients born with other types of CL/P (Oosterkamp et al., 2007). Having a visible cleft was associated with lower overall satisfaction with appearance in three studies (Hunt et al., 2006; Feragen et al., 2015; Gkantidis et al., in press), and with lower satisfaction with cleft-related facial features in two others (Feragen \& Stock, in press; Feragen et al., 2015). Patients with CPO were found to be more satisfied with the appearance of the nose and lip than those with a visible cleft (Gkantidis et al., in press). Having a condition in additional to the cleft was associated with lower overall satisfaction with appearance at age 10 (Feragen \& Stock, in press), but not at age 16 (Feragen et al., 2015), although the effect size was small. Satisfaction with appearance was also found to be significantly lower in South Asian participants when compared to Caucasian participants, particularly in relation to the appearance of the nose (Reekie, 2011). A larger number of surgeries was related to greater satisfaction with appearance in two studies (Demir et al., 2011; Mani et al., 2013), but not in one other (Semb et al., 2005).

Ratings of physical appearance were significantly associated with QoL (Damiano et al., 2007; Mani et al., 2013), general adjustment (Berger \& Dalton, 2011), professional life (Gkantidis, Papamanou, Christou \& Topouzelis, 2013), social experiences (Feragen et al., 2009; Feragen \& Borge, 2010; Murray et al., 2010; Versnel et al., 2010; Gkantidis et al., 2013), mental health and vitality (Oosterkamp et al., 2007), self-esteem (Versnel et al., 2010; Millar et al., 2013), behavioural problems (Wehby et al., 2012; Millar et al., 2013) and withdrawn, anxious 
and/or depressive symptoms (Feragen et al., 2010; Murray et al., 2010; Millar et al., 2013). Further, subjective ratings of appearance mediated the relationship between social experiences and depressive symptoms (Feragen et al., 2010).

\section{Perceptions of Appearance among Professionals and Laypersons}

Sixteen studies asked laypersons, as well as specialist and non-specialist professionals, to assess patient photographs on a range of different measures of aesthetics. Within these studies, patients with CL/P were frequently rated more negatively than controls in relation to facial appearance and symmetry (Meyer-Marcotty, Alpers, Gerdes \& Stellzig-Eisenhauer, 2010; Pitak-Arnnop et al., 2011; Meyer-Marcotty, Kochel, et al., 2011; Eichenberger, Staudt, Pandis, Gnoinski \& Eliades, 2014). Professionals and laypersons highlighted the mid-face region, the nose, the teeth and the upper lip as causing aesthetic impairment (Chetpakdeechit et al., 2011; Ferrari Júnior, Ayub, Capelozza Filho, Pereira Lauris \& Garib, 2015). In two studies, patients with $\mathrm{CL} / \mathrm{P}$ were also perceived to present more negative facial expressions than controls (Meyer-Marcotty, Gerdes, Reuther, et al., 2010; Meyer-Marcotty, Alpers, et al., 2010). Greater objective asymmetry of the face was associated with lower subjective ratings of appearance in one study (Meyer-Marcotty, Gerdes, Reuther, et al., 2010). In one study, males with $\mathrm{CL} / \mathrm{P}$ were rated as being less attractive than females with a cleft according to laypersons (Meyer-Marcotty, Gerdes, et al., 2011).

Fourteen studies compared perceptions of treatment outcomes among patients, laypersons, and specialist and non-specialist professionals. One study found patients' ratings of their own appearance to be lower than ratings provided by professionals (Sinko et al., 2005). In contrast, patients gave more positive ratings of their own appearance when compared to professionals' ratings in three cases (Hens et al., 2011; Gkantidis et al., 2013; Byrne et al., 2014). In an analysís of specific facial features, Meyer-Marcotty and Stellzig-Eisenhauer (2009) found patients to be less satisfied with the nose and lip, while professionals were more concerned with the teeth.

There was a reasonable level of agreement between professionals and laypersons in relation to ratings of appearance in most cases (Meyer-Marcotty \& Stellzig-Eisenhauer, 2009; PitakArnnop et al., 2011; Papamanou, Gkantidis, Topouzelis \& Christou, 2012; Gkantidis et al., 2013; Watterson et al., 2013), with some exceptions. In one study, professionals rated patients as being significantly less attractive in all components of the face than did laypersons (Foo, Sampson, Roberts, Jamieson \& David, 2013), whereas in three studies, professionals 
gave higher ratings of appearance than those provided by laypersons (Chetpakdeechit et al., 2011; Eichenberger et al., 2014; Ferrari Júnior et al., 2015). In four studies, laypersons were found to be the least satisfied group in relation to patients' appearance (Papamanou et al., 2012; Gkantidis et al., 2013; Foo et al., 2013; Eichenberger et al., 2014). Despite not always being satisfied with the treatment outcome, raters tended to report that patients' aesthetics were 'acceptable' overall (Ferrari Júnior et al., 2015; Gkantidis et al., 2015).

\section{Objective Assessment of Aesthetics}

Four studies used 3-Dimensional imaging to assess facial aesthetics objectively. These studies demonstrated patients with CL/P to have significantly more asymmetry of the face than controls (Meyer-Marcotty, Gerdes et al., 2010; Meyer-Marcotty, Gerdes et al., 2011), with the mid-face region showing the most asymmetry (Meyer-Marcotty \& StellzigEisenhauer, 2009; Meyer-Marcotty, Gerdes et al., 2010). However, few clear links were found between objective assessments of appearance and subject eyaluations (Semb et al., 2005; Meyer-Marcotty \& Stellzig-Eisenhauer, 2009; Millar et al., 2013).

\section{Satisfaction with Function}

Satisfaction with function was examined in 12 studies. A variety of functional impairments were reported, including low speech intelligibility, problems with resonance, difficulties with nasal breathing, poor oral health, hearing difficulties, Otitis Media with Effusion (OME), problems with eating and drinking and reduced overall wellbeing (Oosterkamp et al., 2007; Chuo et al., 2008; Ruiter et al., 2009; Collett, Stott-Miller et al., 2010; Bos \& Prahl, 2011; Chimruang et al., 2011; van Lierde et al., 2012; Wehby et al., 2012; Tyler et al., 2013; Knight et al., 2015; Tierney et al., 2015; Aravena et al., in press; Feragen, Særvold et al., in press; Gkantidis et al., in press). In contrast, two studies found levels of satisfaction with function to be high overall (Munz et al., 2011; Gkantidis et al., in press). Few differences in the ratings given by patients, laypersons and professionals were found (Sinko et al., 2005; Brunnegård, Lohmander \& van Doorn, 2009), although only $7 \%$ of the variance in subjective satisfaction with speech was explained by clinicians' assessments in one study (Feragen, Særvold et al., in press).

In a sample of 8-21-year-olds, being older was associated with dissatisfaction with speech (Hunt et al., 2006). In contrast, younger participants (age 8-12 years) reported more symptoms related to functional difficulties (Bos \& Prahl, 2011). Satisfaction with function was found to be significantly lower in those patients with a BCLP when compared to those 
patients born with other types of CL/P (Oosterkamp et al., 2007). Satisfaction with functional outcomes was also found to be significantly lower in South Asian participants when compared to Caucasian participants, especially in relation to speech (Reekie, 2011).

\section{Motivations for Surgical Intervention}

Patients reported wanting further treatment in several studies (Semb et al., 2005; Hunt et al., 2007; Lorot-Marchand et al., 2015), with nose and lip corrections being the most sought-after procedures (Semb et al., 2005; Sinko et al., 2005; Chuo et al., 2008; Lorot-Marchand et al., 2015). Motivations for undergoing further treatment included dissatisfaction with appearance (Augsornwan, Namedang, Pongpagatip \& Surakunprapha, 2011; Tiemens et a1,, 2013; Byrne et al., 2014; Lorot-Marchand et al., 2015), low self-perceptions (Alansari et al., 2013; Tiemens et al., 2013), a desire to improve speech (Sharp et al., 2008), a desire to reduce nasal obstruction (Hens et al., 2011) and social benefits (Sharp et al., 2008; Augsornwan et al., 2011; Tiemens et al., 2013). However, patients, professionals and laypersons frequently disagreed on whether further treatment was necessary. In contrast to the findings above, patients did not often believe additional treatment was needed, despite professionals and laypersons believing patients would benefit (Sinko et al., 2005; Meyer-Marcotty \& StellzigEisenhauer, 2009; Foo et al., 2013; Nkenke et al., 2013; Stock et al., 2015).

A number of other studies described reasons for treatment refusal, which included patients' reports of feeling satisfied with treatment, having positive self-perceptions, being able to cope, believing no more could be done, a fear of the treatment failing or being tired of treatment (Havstam, Laakso \& Ringsberg, 2011; Hall et al., 2012; Alansari et al., 2013; Stock et al., 2015). Patients were more likely to refuse treatment, or to find the decision-making process more difficult if the procedure was for cosmetic reasons only (Havstam, Laakso \& Ringsberg, 2011; Hall, Gibson, James \& Rodd, 2012). Some patients had also declined treatment due to a fear of the treatment failing (Hall et al., 2012; Stock et al., 2015). Managing patients' expectations of treatment was considered to be an important factor in the decision-making process (Stock, Feragen et al., in press). Experiences of treatment during childhood shaped patients' decision process when considering optional surgeries offered at a later stage (Alansari et al., 2013; Stock, Feragen et al., in press). In a sample of 8-17-yearolds, young people were found to adopt their own measures to improve appearance, including wearing make-up and nice clothes (Hall et al., 2012). Some only took photographs from their 
'best side' and some consciously smiled more to make their cleft less noticeable (Hall et al., 2012).

\section{Experiences of Treatment}

Eight studies described patients as feeling nervous, intimidated by and/or frightened of treatment and clinic appointments (Noor \& Musa, 2007; Luoto, Lahti, Nevanpera, Tolvanen \& Locker, 2008; Bos \& Prahl, 2011; Vogels, Aartman \& Veerkamp, 2011; Hall et al., 2012; Dogan, Serin, Uzel \& Seydaoglu, 2013; Krikken et al., 2015; Tierney et al., 2015), while others reported that treatment could be burdensome (Chetpakdeechit et al., 2009; Havstam, Laakso \& Ringsberg, 2011; Alansari et al., 2013). Females reported more concern about treatment than males in two studies (Luoto et al., 2008; Bos \& Prahl, 2011). Treatment anxiety was highest in children aged four to six years (Vogels et al., 2011), but was generally found to reduce with age and with previous experience of treatment (Luoto et al., 2008; Dogan et al., 2013; Krikken et al., 2015). Some patients felt it was difficult for them to discuss concerns with specialists, while others reported feeling more confident in expressing their views (Noor \& Musa, 2007; Hall et al., 2012). Patients raised concerns about feeling pressured to comply with treatment recommendations and/or having a lack of influence over treatment decisions (Noor \& Musa, 2007; Havstam, Laakso \& Ringsberg, 2011; Hall et al., 2012; Stock et al., 2015). Concurrently, the importance of treatment autonomy and involvement was discussed in a number of studies (Semb et al., 2005; Noor \& Musa, 2007; Chuo et al., 2008; Hall et al., 2012; Stock, Feragen et al., in press). Some patients reported that they found clinic information difficult to understand (Noor \& Musa, 2007), and felt that information provision and treatment referrals could be improved (Augsornwan et al., 2011; Hamlet \& Harcourt, 2015; Stock \& Rumsey, 2015; Stock et al., 2015). Treatment for CL/P was often described as a process, rather than an event (Hall et al., 2013; Alansari et al., 2013; Gkantidis et al., 2013).

Treatment experiences were associated with a wide range of factors. Hospital appointments and undergoing treatment affected feelings of normality and social acceptance according to one study (Havstam, Laakso \& Ringsberg, 2011). Patients who reported fear of treatment reported the use of more coping skills (Vogels et al., 2011) and poorer emotional and social wellbeing (Luoto et al., 2008). Children with more episodes of treatment reported a more positive mental state in two studies (Luoto et al., 2008; Demir et al., 2011), while a higher number of surgeries was associated with increased anxiety, depression, somatic symptoms 
(Wehby et al., 2012), lower overall emotional wellbeing and poorer HRQoL (Broder et al., 2012) according to two other studies. In contrast, one study reported that satisfaction with treatment was not correlated with patients' social or psychological QoL (Munz et al., 2011). Low socioeconomic status was described as a barrier to attending treatment appointments in two studies (Smillie, Yong, Harris, Wynne \& Russell, 2015; Stock, Feragen et al., in press).

\section{Satisfaction following Medical Intervention}

Thirteen studies investigated parent and patient satisfaction with treatment outcome following completion of treatment or after a surgical intervention. Overall, a high level of parent and patient satisfaction with treatment outcome was described (Semb et al., 2005; Damiano et al., 2006; Noor \& Musa, 2007; Hens et al., 2011; Munz et al., 2011; Pitak-Arnnop et al., 2011; Byrne et al., 2014; Stock et al., 2015). Patients reported that their appearance (Sandor \& Ylikontiola, 2006; Sharp et al., 2008; Hens et al., 2011; Byrne et al.,2014) and function (Sharp et al., 2008; Hens et al., 2011) had improved as a result of treatment, that they would undergo the treatment again knowing the result (Sandor \& Ylikontiola, 2006; Hens et al., 2011; Byrne et al., 2014), and that they would recommend the treatment or procedure to others (Sharp et al., 2008). Professionals were also satisfied with post-operative appearance on the whole (Byrne et al., 2014). However, a minority of patients and professionals stated they were 'uncertain', believed there to be 'no improvement', or felt that appearance and/or function had 'worsened' (Noor \& Musa, 2007; Hens et al., 2011; Byrne et al., 2014). Two qualitative studies reported that treatment did not always yield results which outweighed the burden associated with treatment (Alansari et al., 2013; Stock et al., 2015). Satisfaction with treatment varied according to the type of procedure performed in three cases (Cheung et al., 2006; Landsberger et al., 2006; Pitak-Arnnop et al., 2011), and with the amount of pain experienced in two studies (Munz et al., 2011; Alansari et al., 2013). Three studies found discrepancies in satisfaction with appearance and treatment outcomes between patient and parent reports. In some cases, the parents reported being more satisfied with the patient's treatment outcomes than the patients themselves (Berger \& Dalton, 2009; Munz et al., 2011). Five other studies found moderate agreement between patients and parents (Semb et al., 2005; Noor \& Musa, 2007; van Lierde et al., 2012; Gkantidis et al., 2013; Gkantidis et al., in press).

\section{Timing of Surgery}

According to parent reports, children who had their cleft lip repaired within a few days of birth scored more highly on measures of self-esteem than those children who had their cleft 
lip repaired at three to six months of age (Petráčková et al., 2015). Patients undergoing cleft repair at three to four months of age scored significantly lower on tests of verbal IQ, full IQ and grammar compared to those undergoing cleft repair neonatally (Hentges et al., 2011), while IQ was not related to timing of repair in another study (Petrackova et al., 2015). Additionally, undergoing cleft repair at three to four months of age was related to poorer cognitive development, while those undergoing neonatal repair had cognitive scores which were comparable to controls (Murray et al., 2008).

\section{General Adjustment and Wellbeing}

\section{Quality of Life and Health-Related Quality of Life}

According to five studies, the influence of CL/P on total QoL was found to be low (Kramer et al., 2008; Augsornwan et al., 2011; Smith et al., 2014; Stock et al.,2015; Aravena et al., in press). No differences were found in relation to QoL scores according to cleft type (Kramer et al., 2008). Overall QoL was related to self-concept, self-perceptions of mastery (Broder, Wilson-Genderson \& Sischo, 2014), self-esteem and coping styles (Pisula et al., 2014). Differences between patient and parent reports were found in one study, with higher levels of QoL being reported by patients (Kramer et al., 2008). No differences were found between individuals with CL/P and controls in relation to total HRQoL scores in three studies (Oosterkamp et al., 2007; Sagheri etal., 2009; Mani et al., 2010). Younger children with CLP (2-7 years) had higher HRQoL scores than same-aged children with CPO, although this pattern was reversed for older children (8-12 years; Damiano et al., 2007).

\section{General Adjustment}

Individuals with CL/P did not score differently to norms in terms of overall psychological adjustment according to two studies (Berger \& Dalton, 2009; Smith et al., 2014). According to one study, nineteen percent of adolescents reported that they had experienced no problems relating to their cleft (Berger \& Dalton, 2009). Differences between patient and parent reports were found in one study, with higher adjustment scores being reported by patients (Berger \& Dalton, 2009). Boys with CL/P reported greater adjustment difficulties than girls with a cleft, although scores were still within the normal range, irrespective of age and cleft type (Berger \& Dalton, 2009). According to another study, children with a non-visible cleft had significantly fewer adjustment problems than those with a visible cleft according to one other, while children with an additional condition were found to have significantly more 
psychological difficulties than those with a cleft only, although scores were within the normal range for all subgroups (Feragen \& Stock, in press).

\section{The decision to have children}

Four studies investigated the influence of psychological adjustment to CL/P on adults' decision to have children. In one study, childlessness was higher among women born with $\mathrm{CL} / \mathrm{P}$ compared to women in the general population, especially among women with a CPO (Yttri, Christensen, Knudsen \& Bille, 2011). The average age for women with CL/P to have their first child was also older than women without CL/P. However, if women with CL/P did have children, there was no significant difference in regard to the number of children (Yttri et al., 2010). In one study, having an affected first child was a better predictor of future fertility rates than the mother being affected with CL/P herself (Wehby, Nyarko \& Murray, 2014). Concerns regarding the recurrence risk of CL/P were mentioned by three studies (O'Hanlon, Camic \& Shearer, 2012; Stock \& Rumsey, 2015; Stock et al., 2015). However, O’Hanlon and colleagues (2012) found few significant differences in adjustment between parents with and without a diagnosis of CL/P, and Stock and Rumsey (2015) reported a number of beneficial outcomes, including the potential to create a positive cycle of adjustment among generations.

\section{Discussion}

\section{Synthesis of Findings}

In this narrative review of the literature, findings from studies pertaining to the psychological adjustment of individuals with CL/P and published during the last decade (Jan 2004-July 2015) were presented. Findings were categorised according to five key domains:

'Developmental Trajectory', 'Behaviour', 'Emotional Wellbeing', 'Social Experiences' and 'Satisfaction with Appearance and Treatment'. Contributing variables, such as gender, age, ethnicity, cleft type, the presence of additional conditions and socioeconomic status were also identified. In addition, findings relating to overall QoL, HRQoL and general psychological wellbeing were provided. Finally, associations between domains of adjustment were examined.

In 2005, the comprehensive review published by Hunt and colleagues concluded that while the majority of individuals born with $\mathrm{CL} / \mathrm{P}$ do not appear to experience major psychological problems, some specific problems in relation to satisfaction with appearance, behaviour, 
depression and anxiety may arise. In addition, reports of self-concept, satisfaction with appearance, depression, attachment, learning problems and interpersonal relationships were thought to vary by cleft type. These conclusions will now be discussed in relation to the findings of the current review.

In the present review, dissatisfaction with appearance seemed to be a prevalent concern. However, this concern may actually be comparable to, or better than the levels of appearance dissatisfaction being reported among the general population, and elevated only in relation to the facial features affected by the cleft. This is an interesting development for the field and calls into question the tendency for studies to assess satisfaction with appearance predominantly in relation to treatment. These findings suggest the need to distinguish between perceptions of general physical appearance and aspects of appearance integral to CL/P. Satisfaction with appearance is also known to vary according to age and gender in both the general population and among individuals with visible conditions (Smolak, 2004; Rumsey \& Harcourt, 2012); factors which are difficult to decipher without large and age-appropriate samples, in addition to appropriate reference or control groups. What is clear is that dissatisfaction with appearance can impact upon many domains of psychological functioning, and therefore a clearer understanding of the factors which contribute to the development and maintenance of appearance concern in this population is needed. The ways in which cleft treatment to improve aesthetics interacts with these relationships also requires further consideration. Motivations for and expectations of treatment were highlighted in the present review, along with patient perceptions of treatment autonomy and relationships with health professionals.

Fewer papers evaluating the behaviour of those born with CL/P appear to have been published since the review by Hunt et al. (2005). When overall behavioural conduct is measured, few difficulties are found. However, high levels of internalising/externalising behaviours, as well as elevated levels of inattention/hyperactivity have been reported. It could be that behavioural difficulties are in fact an expression of underlying emotional, cognitive or neurological problems, and/or related to the presence of an additional condition. Four studies proposed that behavioural difficulties may be misdiagnosed among individuals with CL/P. In addition, the relatively small number of studies included in this domain in the current review could suggest a shift in the focus of recent research and/or illustrates that the way in which domains of adjustment are conceptualised affects the decision of where to place the research findings. This review therefore raises an important consideration in relation to how behavioural and 
psychological problems are conceptualised, assessed and reported in both clinical practice and within research samples.

The current review does not lend full support to the previous finding that levels of anxiety and depression are raised among individuals with CL/P (Hunt et al., 2005). Rather, the picture appears to be more complex and affected by numerous confounders. This discussion is also relevant in regard to studies investigating self-concept and self-esteem. However, a number of recent studies have begun to investigate associations between emotional functioning and other domains of adjustment, such as positive and negative social experiences. This seems to be a positive step forward for the field in terms of understanding whether the cleft, or other factors, are responsible for emotional distress and poorer self-perceptions, and could help to identify the subgroups which may be most vulnerable.

The current review presents a more thorough investigation of cognitive functioning than the earlier review by Hunt et al., (2005), and may reflect an increase in interest in this area. The previously reported prevalence of learning problems among individuals with CL/P was confirmed, and although general IQ does not seem to be affected, some specific deficits in cognitive and language development have been repeatedly demonstrated. However, these findings are likely affected by the presence of additional conditions and/or neurological abnormalities demonstrated by recent investigations. In addition, some consensus that outcomes may be most affected in individuals with a cleft palate, compared to a cleft lip alone, was tentatively identified. Again, this may be related to the presence of neurological and/or developmental conditions, and thus additional investigation is necessary. A range of other factors may impact upon educational and vocational achievement, including hearing difficulties, school absences, support from teachers and social experiences. Further research is needed to understand these possible deficits in learning, how they may affect individuals within tangible contexts and the type of additional support and intervention which may be needed.

As reported in the Hunt et al. (2005) review, findings as to whether parent-infant interactions are affected in CL/P were mixed. However, in comparison to the review by Hunt and colleagues (2005), the current review cannot conclude whether attachment representations are influenced by more 'severe' cleft types. Nonetheless, parent-infant interactions, as well as family functioning more generally, appear to impact to some degree upon the child's early development and later adjustment. Further investigation of these relationships and the 
implementation of appropriate support for families throughout the entire treatment journey is needed (Nelson et al., 2012).

Contradictory findings were identified in the current review in relation to the overall social functioning of individuals affected by CL/P. However, in accordance with the review by Hunt et al., raised levels of specific concerns, including self-consciousness or anxiety in connection with social situations, were observed. Recent research has begun to advance the field via the investigation of contributory factors such as communication difficulties and the influence of perceived teasing and feelings of social acceptance. Thus, although measurement of societal attitudes towards visible difference is intriguing and of value to organisations campaigning for appearance ‘equality' (www.changingfaces.org.uk), a focus of individuallevel interventions should be to address the more amenable areas of patients' social perceptions and social competence. In addition, further research is needed to address the question of whether romantic relationships and decisions to have children are affected by having $\mathrm{CL} / \mathrm{P}$.

\section{Methodological Considerations}

The review by Hunt and colleagues (2005) identified several methodological concerns and made a number of recommendations for future research. Utilising the findings of the current review, the degree to which these recommendations have been met will now be examined.

Hunt et al. (2005) reported that more than half of studies included in their review did not use an appropriate control group. The current review distinguished between studies using control groups and those using reference groups, registry databases and/or norms. When taking these factors into account, only $24.8 \%$ of the studies included in the current review did not include an appropriate comparison group. Although the figures from the two reviews cannot be directed compared, these calculations do suggest an improvement in the number of studies using an appropriate comparison group during recent years. One additional and significant consideration is that individuals with CL/P may report scores which are lower than controls, but still within the normal range. The inclusion of norms, including cut-off scores to aid interpretation, is therefore strongly recommended. In addition, caution in regard to the generalisation of findings should be taken when considering the results of separate studies which have utilised data extracted from the same cohort of participants.

Hunt and colleagues (2005) also identified a relative lack of longitudinal studies within the available literature (14\%). In the current review, only 5\% studies measured variables at two 
time points or more, albeit during a much shorter time period, suggesting overall that the field has somewhat responded to this need. Nonetheless, the number of studies using a longitudinal approach is clearly comparatively small and must be increased in order for changes in psychological adjustment over time to be explored.

Much like Hunt et al. (2005), the current review was unable to draw conclusions regarding the effect of age on psychological adjustment to CL/P, since results are predominantly confounded by a wide age range spanning several stages of development. Coupled with a small sample size, results are often indecipherable. The challenges of collecting large samples are well acknowledged in this field. However, efforts must be doubled if we are to investigate subgroups, such as gender, ethnicity, cleft type, additional conditions and other demographic variables effectively. Further, Hunt's recommendation of multi-centre studies is just as valid today.

The review by Hunt et al. (2005) reported that a wide variety of measures were in use, making it difficult to compare the results from different studies directly. Unfortunately, this still seems to be the case. A number of recent reviews have also demonstrated the quantity of measures available, coupled with a lack of agreement about what should be measured, how and when (Eckstein, Wu, Akinbiyi, Silver, \& Taub, 2011; Klassen et al., 2012; Ranganathan et al., 2015). Psychological adjustment is multifactorial and difficult to capture, making the process of achieving consensus in regard to measurement considerably challenging. Due largely to the centralisation of cleft treatment, progress has recently been made in the UK (Stock, Feragen et al., in press), and elsewhere (Broder, 2014; Semb, 2014). This type of approach could provide a foundation for integrating standardised patient-centred measurement in countries around the world.

Another important methodological consideration identified by Hunt et al. (2005) was discrepancies in the reporting of outcomes depending on the informant. In the current review, many more studies included the patient perspective, and an increase in qualitative work is visible (see also Nelson, 2009). However, several studies still relied solely upon reports from parents, teachers, laypersons and/or health professionals. Collecting multiple perspectives can be informative and is encouraged, but should always seek to include the patients' view.

Finally, Hunt and colleagues (2005) stated that a shift in focus 'towards the strengths rather than the deficits' of the affected individual, was necessary. These suggestions were supported at the time by two other discussion papers (Eiserman, 2001; Strauss, 2001). The current 
review has demonstrated that measures of positive adjustment and resilience are beginning to be included in CL/P studies (e.g. Feragen et al., 2009; Chimruang et al., 2011; Gassling et al., 2012; Pisula et al., 2014; Stock et al., 2015; Stock, Feragen et al., in press). This progress should be built upon to provide a more balanced view of adjustment and to allow for the assessment of points of opportunity as well as risk.

A more thorough investigation of conceptual and methodological challenges within the field of $\mathrm{CL} / \mathrm{P}$ has recently been offered (manuscript in preparation). Future studies interested in the psychological adjustment of individuals affected by CL/P and their families are encouraged to take this critique into consideration, in order to advance progress within the field as a whole.

\section{Conclusions}

As suggested in a previous and comprehensive literature review (Hunt et al., 2005), the current narrative review found the impact of CL/P on overall psychological adjustment and QoL to be low when examining total scores. However, potential difficulties are found when examining key domains of adjustment in more detail. Despite the volume of work conducted in this area during the last decade, research findings still appear to be largely inconclusive, and marred by similar methodological challenges as noted by Hunt et al. in 2005 . Nonetheless, the present review identified some areas of emerging consensus, and a number of recent improvements in the approaches used are visible. Efforts to collect data from large, representative and longitudinal samples, which are comparable across studies and encompassing of both the patient perspective and measures of resilience, should be doubled.

\section{References}

Abd-Elsayed, A.A., Delgado, S.V. \& Livingstone, M. (2013). Self-image perception of 171 children and adolescents with cleft lip and palate from 22 countries. The Ochsner Journal, 13, 204-207.

Adamson, C.L., Anderson, V.A., Nopoulos, P., Seal, M.L. \& da Costa, A.C. (2014). Regional brain morphometric characteristics of nonsyndromic cleft lip and palate. Developmental Neuroscience, 36, 490-498. doi: $10.1159 / 000365389$.

Alansari, R., Bedos, C. \& Allison, P. (2014). Living with cleft lip and palate: The treatment journey. The Cleft Palate-Craniofacial Journal, 51, 222-229. doi: 10.1597/12-255.

Antonarakis, G.S., Patel, R.N. \& Tompson, B. (2013). Oral health-related quality of life in non-syndromic cleft lip and/or palate patients: A systematic review. Community Dental Health, 30, 189-195. 
Aravena, P.C., Gonzalez, T., Oyarzun, T. \& Coronado, C. (in press). Oral health-related quality of life in children in Chile treated for cleft lip and palate: A case-control approach. The Cleft Palate-Craniofacial Journal, in press. doi: 10.1597/15-095.

Augsornwan, D., Namedang, S., Pongpagatip, S. \& Surakunprapha, P. (2011). Quality of life in patients with cleft lip and palate after operation. Journal of the Medical Association of Thailand, 94, S124-S128.

Bashir, M.A., Hodgkinson, P.D., Montgomery, T. \& Splitt, M. (2008). 22Q11 deletion in children with cleft lip and palate - is routine screening justified? Journal of Plastic, Reconstructive \& Aesthetic Surgery, 61, 130-132. doi: 10.1016/j.bjps.2007.06.018.

Berger, Z.E. \& Dalton, L.J. (2009). Coping with a cleft: Psychosocial adjustment of adolescents with a cleft lip and palate and their parents. The Cleft Palate-Craniofacial Journal, 46, 435-443. doi: 10.1597/08-093.1.

Berger, Z.E. \& Dalton, L.J. (2011). Coping with a cleft II: Factors associated with psychosocial adjustment of adolescents with a cleft lip and palate and their parents. The Cleft Palate-Craniofacial Journal, 48, 82-90. doi: 10.1597/08-094.

Boes, A.D., Murko, V., Wood, J.L., Langbehn, D.R., Canady, J., Richman, L. \& Nopoulos, P. (2007). Social function in boys with cleft lip and palate: Relationship to ventral frontal cortex morphology. Behavioural Brain Research, 181, 224-231. doi: 10.1016/j.bbr.2007.04.009.

Bos, A. \& Prahl, C. (2011). Oral health-related quality of life in Dutch children with cleft lip and/or palate. The Angle Orthodontist, 81, 865-871. doi: 10.2319/070110-365.1.

Brand, S., Blechschmidt, A., Müller, A., Sader, R., Schwenzer-Zimmerer, K., Zeilhofer, H.-F. \& HolsboerTrachsler, E. (2009). Psychosocial functioning and sleep patterns in children and adolescents with cleft lip and palate (CLP) compared with healthy controls. The Cleft Palate-Craniofacial Journal, 46, 124-135. doi: 10.1597/07-1651.1.

Broder, H.L. (2014). International confederation for cleft lip and palate and related craniofacial anomalies task force report: Holistic Outcomes. The Cleft Palate-Craniofacial Journal, 51, e130-134. doi: 10.1597/14.122.

Broder, H.L., Wilson-Genderson, M. \& Sischo, L. (2012). Health disparities among children with cleft. American Journal of Public Health, 102, 828-830. doi: 10.2105/AJPH.2012.300654.

Broder, H.L., Wilson-Genderson, M. \& Sischo, L. (2014). Examination of a theoretical model for oral healthrelated quality of life among youths with cleft. American Journal of Public Health, 104, 865-871. doi: 10.2105/AJPH.2013.301686.

Brunnegård, K., Lohmander, A. \& van Doorn, J. (2009). Untrained listeners' ratings of speech disorders in a group with cleft palate: A comparison with speech and language pathologists' ratings. International Journal of Language and Communication Disorders, 44, 656-674. doi: 10.1080/13682820802295203.

Burnell, L., Verchere, C., Pugash, D., Loock, C., Robertson, S. \& Lehman, A. (2014). Additional post-natal diagnoses following antenatal diagnosis of isolated cleft lip +/- palate. Archives of Disease in Childhood: Fetal \& Neonatal Edition, 99, 286-290. doi: 10.1136/archdischild-2013-305390.

Byrne, M., Chan, J.C.Y. \& O'Broin, E. (2014). Perceptions and satisfaction of aesthetic outcome following secondary cleft rhinoplasty: Evaluation by patients versus health professionals. Journal of Cranio-MaxilloFacial Surgery, 42, 1062-1070. doi: 10.1016/j.jcms.2014.01.031.

Chan, R.K.K., McPherson, B. \& Whitehill, T.L. (2006). Chinese attitudes toward cleft lip and palate: Effects of personal contact. The Cleft Palate-Craniofacial Journal, 43, 731-739. doi: 10.1597/05-111.

Chetpakdeechit, W., Hallberg, U., Hagberg, C. \& Mohlin, B. (2009). Social life aspects of young adults with cleft lip and palate: Grounded Theory approach. Acta Odontologica Scandinavia, 67, 122-128. doi: 10.1080/00016350902720888.

Chetpakdeechit, W., Mohlin, B., Persson, C. \& Hagberg, C. (2010). Cleft extension and risks of other birth defects in children with isolated cleft palate. Acta Odontologica Scandinavica, 68, 86-90. doi: $10.3109 / 00016350903258003$.

Chetpakdeechit, W., Wahss, J., Woo, T., Hugander, M., Mohlin, B. \& Hagberg, C. (2011). Esthetic views on facial and dental appearance in young adults with treated bilateral cleft lip and palate (BCLP). A comparison between professional and non-professional evaluators. Swedish Dental Journal, 35, 151-157. 
Cheung, L.K., Loh, J.S.P. \& Ho, S.M.Y. (2006). The early psychological adjustment of cleft patients after maxillary distraction osteogenesis and conventional orthognathic surgery: A preliminary study. Journal of Oral and Maxillofacial Surgery, 64, 1743-1750.

Cheung, L.K., Loh, J.S.P. \& Ho, S.M.Y. (2007). Psychological profile of Chinese with cleft lip and palate deformities. The Cleft Palate-Craniofacial Journal, 44, 79-86. doi: 10.1597/05-053.

Chimruang, J., Soadmanee, O., Srisilapanan, P., Patjanasoontorn, N., Nanthavanich, N. \& Chuawanlee, W. (2011). A qualitative study of health-related quality of life and psychosocial adjustments of Thai adolescents with repaired cleft lips and palates. Journal of the Medical Association of Thailand, 94, S45-50.

Chuo, C.B., Searle, Y., Jeremy, A., Richard, B.M., Sharp, I. \& Slator, R. (2008). The continuing multidisciplinary needs of adult patients with cleft lip and/or palate. The Cleft Palate-Craniofacial Journal, 45 , 633-638. doi: 10.1597/07-048.1.

Collett, B.R. \& Speltz, M.L. (2007). A developmental approach to mental health for children and adolescents with orofacial clefts. Orthodontics \& Craniofacial Research, 10, 138-148. doi: 10.1111/j.16016343.2007.00394.x.

Collett, B.R., Leroux, B. \& Speltz, M.L. (2010). Language and early reading among children with orofacial clefts. The Cleft Palate-Craniofacial Journal, 47, 284-292. doi: 10.1597/08-172.1.

Collett, B.R., Stott-Miller, M., Kapp-Simon, K.A., Cunningham, M.L. \& Speltz, M.L. (2010). Reading in children with orofacial clefts versus controls. Journal of Pediatric Psychology, 35, 199-208. doi: 10.1093/jpepsy/jsp047.

Collett, B.R., Cloonan, Y.K., Speltz, M.L., Anderka, M. \& Werler, M.M. (2012). Psychosocial functioning in children with and without orofacial clefts and their parents. The Cleft Palate Craniofacial Journal, 49, $397-405$. doi: $10.1597 / 10-007$.

Collett, B.R., Wehby, G.L., Barron, S., Romitti, P.A., Ansley, T.N. \& Speltz, M.L. (2014). Academic achievement in children with oral clefts versus unaffected siblings. Journal of Pediatric Psychology, 39, 743751. doi: 10.1093/jpepsy/jsu049.

Conrad, A.L., Canady, J., Richman, L. \& Nopoulos, P. (2008). Incidence of neurological soft signs in children with isolated cleft of the lip or palate. Perceptual and Motor Skills, 106, 197-206.

Conrad, A.L., Richman, L., Nopoulos, P. \& Dailey, S. (2009). Neuropsychological functioning in children with non-syndromic cleft of the lip and/or palate. Child Neuropsychology, 15, 471-484. doi: 10.1080/09297040802691120.

Conrad, A.L., McCoy, T.E., deVolder, I., Richman, L.C. \& Nopoulos, P. (2014). Reading in subjects with an oral cleft: Speech, hearing and neuropsychological skills. Neuropsychology, 28, 415-422. doi:

10.1037/neu0000024.

Crerand, C.E., Rosenberg, J., Magee, L., Stein, M.B., Wilson-Genderson, M. \& Broder, H.L. (2015). Parentreported family functioning among children with cleft lip/palate. The Cleft Palate-Craniofacial Journal, 52, 651659. doi: 10.1597/14-050.

Damiano,P.C., Tyler, M.C., Romitti, P.A., Momany, E.T., Canady, J.W., Karnell, M.P. \& Murray, J.C. (2006). Type of oral cleft and mothers' perceptions of care, health status and outcomes for preadolescent children. The Cleft Palate-Craniofacial Journal, 43, 715-721.

Damiano, P.C., Tyler, M.C., Romitti, P.A., Momany, E.T., Jones, M.P., Canady, J.W., Karnell, M.P. \& Murray, J.C. (2007). Health-related quality of life among preadolescent children with oral clefts: The mother's perspective. Pediatrics, 120, e283-e290. doi: 10.1542/peds.2006-2091.

Demir, T., Karacetin, G., Baghaki, S. \& Aydin, Y. (2011). Psychiatric assessment of children with nonsyndromic cleft lip and palate. General Hospital Psychiatry, 33, 594-603. doi: 10.1016/j.genhosppsych.2011.06.006.

Despars, J., Peter, C., Borghini, A., Pierrehumbert, B., Habersaat, S., Müller-Nix, C., Ansermet, F. \& Hohlfeld, J. (2011). Impact of a cleft lip and/or palate on maternal stress and attachment representations. The Cleft Palate Craniofacial Journal, 48, 419-424. doi: 10.1597/08-190.

De Sousa, A., Devare, S. \& Ghanshami, J. (2009). Psychological issues in cleft lip and cleft palate. Journal of Indian Association of Pediatric Surgeons, 14, 55-58. doi: 10.4103/0971-9261.55152. 
Dimberg, L., Arnrup, K. \& Bondemark, L. (2015). The impact of malocclusion on the quality of life among children and adolescents: A systematic review of quantitative studies. European Journal of Orthodontics, 37, 238-247. doi: 10.1093/ejo/cju046.

Dogan, M.C., Serin, B.A., Uzel, A. \& Seydaoglu, G. (2013). Dental anxiety in children with cleft lip and palate: A pilot study. Oral Health \& Preventative Dentistry, 11, 141-146. doi: 10.3290/j.ohpd.a29364.

Eckstein, D.A., Wu, R.L., Akinbiyi, T., Silver, L. \& Taub, P.J. (2011). Measuring quality of life in cleft lip and palate patients: Currently available patient-reported outcomes measures. Plastic and Reconstructive Surgery, 128, 518e-526e. doi: 10.1097/PRS.0b013e31822b6a67.

Egan, K., Harcourt, D., Rumsey, N. \& Appearance Research Collaboration. (2011). A qualitative study of the experiences of people who identify themselves as having adjusted positively to a visible difference. Journal of Health Psychology, 16, 739-749. doi: 10.1177/1359105310390246.

Eichenberger, M., Staudt, C.B., Pandis, N., Gnoinski, W. \& Eliades, T. (2014). Facial attractiveness of patients with unilateral cleft lip and palate and of controls assessed by laypersons and professionals. European Journal of Orthodontics, 36, 284-289. doi: 10.1093/ejo/cjt047.

Eide, M.G., Skjærven, R., Irgens, L.M., Bjerkedal, T. \& Øyen, N. (2006). Associations of birth defects with adult intellectual performance, disability and mortality: Population-based cohort study. Pediatric Research, 59, 848-853. doi: 10.1203/01.pdr.0000219172.16638.f9.

Eiserman, W. (2001). Unique outcomes and positive contributions associated with facial difference: Expanding research and practice. The Cleft Palate-Craniofacial Journal, 38, 236-244. doi: 10.1597/1545-1569.

Eslami, N., Majidi, M.R., Aliakbarian, M. \& Hasanzadeh, N. (2013). Oral health-related quality of life in children with cleft lip and palate. Journal of Craniofacial Surgery, 24, doi: 10.1097/SCS.0b013e31828b743b.

Feragen, K.B. \& Borge, A.I.H. (2010). Peer harassment and satisfaction with appearance in children with and without a facial difference. Body Image, 7, 97-105. doi: 10.1016/j.bodyim.2009.12.001.

Feragen, K.B., Borge, A.I.H. \& Rumsey, N. (2009). Social experience in 10-year-old children born with a cleft: Exploring psychosocial resilience. The Cleft Palate-Craniofacial Journal, 46, 65-74. doi: 10.1597/07-124.1.

Feragen, K.B., Kvalem, I.L., Rumsey, N. \& Borge, A.I.H. (2010). Adolescents with and without a facial difference: The role of friendships and social acceptance in perceptions of appearance and emotional resilience. Body Image, 7, 271-279. doi: 10.1016/j.bodyim.2010.05.002.

Feragen, K.B. \& Stock, N.M. (2014). When there is more than a cleft: Psychological adjustment when a cleft is associated with an additional condition. The Cleft Palate-Craniofacial Journal, 51, 5-14. doi: 10.1597/12-328.

Feragen, K.B. \& Stock, N.M. (in press). Risk and protective factors at age 10: Psychological adjustment in children with a cleft lip and/or palate. The Cleft Palate-Craniofacial Journal, in press. doi: 10.1597/14-062.

Feragen, K.B., Stock, N.M. \& Kvalem, I. (2015). Risk and protective factors at age 16: Psychological adjustment in children with a cleft lip and/or palate. The Cleft Palate Craniofacial Journal, 52, 555-573. doi: 10.1597/14063.

Feragen, K.B., Stock, N.M. \& Rumsey, N. (2014). Toward a reconsideration of inclusion and exclusion criteria in cleft lip and palate: Implications for psychological research. The Cleft Palate-Craniofacial Journal, 51, 569578. doi: $10.1597 / 12-326$.

Feragen, K.B., Særvold, T.K., Aukner, R. \& Stock, N.M. (in press). Speech, language and reading in 10-yearolds with cleft: Associations with teasing, satisfaction with speech and psychological adjustment. The Cleft Palate-Craniofacial Journal, in press. doi: 10.1597/14-242.

Ferrari Júnior, F.M., Ayub, P.V., Capelozza Filho, L., Pereira Lauris, J.R. \& Garib, D.G. (2015). Esthetic evaluation of the facial profile in rehabilitated adults with complete bilateral cleft lip and palate. Journal of Oral and Maxillofacial Surgery, 73, 169.e1-6. doi: 10.1016/j.joms.2014.09.012.

Foo, P., Sampson, W., Roberts, R., Jamieson, L. \& David, D. (2013). Facial aesthetics and perceived need for further treatment among adults with repaired cleft as assessed by cleft team professionals and laypersons. European Journal of Orthodontics, 35, 341-346. doi: 10.1093/ejo/cjr129. 
Frederickson, M.S., Chapman, K.L. \& Hardin-Jones, M. (2006). Conversational skills of children with cleft lip and palate: A replication and extension. The Cleft Palate-Craniofacial Journal, 43, 179-188. doi: 10.1597/04086.1 .

Gassling, V., Holterhus, P.-M., Herbers, D., Kulle, A., Niederberger, U., Hedderich, J., Wiltfang, J. \& Gerber, W.-D. (2012). Stress-coping and cortisol analysis in patients with non-syndromic cleft lip and palate: An explorative study. PLoS One, 7, e41015. doi: 10.1371/journal.pone.0041015.

Gassling, V., Christoph, C., Wahle, K., Koos, B., Wiltfang, J., Gerber, W.-D. \& Siniatchkin, M. (2014). Children with a cleft lip and palate: An exploratory study of the role of the parent-child interaction. Journal of CranioMaxillo-Facial Surgery, 42, 963-968. doi: 10.1016/j.jcms.2014.01.016.

Gassling, V., Kessler, H., Klein, M.O., Detjen, A.-M., Koos, B., Limbrecht-Ecklundt, K., Traue, H.C., Wiltfang, J. \& Gerber, W.-D. (2014). Normal emotion regulation in adults with cleft lip and palate: An exploratory study. Journal of Cranio-Maxillo-Facial Surgery, 42, 1271-1276. doi: 10.1016/j.jcms.2014.03.009.

Gkantidis, N., Papamanou, D.A., Christou, P. \& Topouzelis, N. (2013). Aesthetic outcome of cleft lip and palate treatment: Perceptions of patients, families and health professionals compared to the general public. Journal of Cranio-Maxillo-Facial Surgery, 41, e106-e110. doi: 10.1016/j.jcms.2012.11.034.

Gkantidis, N., Papamanou, D.A., Karamolegkou, M. \& Dorotheou, D. (in press). Esthetic, functional and everyday life assessment of individuals with cleft lip and/or palate. Biomed Research International, in press. doi: $10.1155 / 2015 / 510395$.

Goldsberry, G., O'Leary, D., Hichwa, R. \& Nopoulos, P. (2006). Functional abnormalities in the neural circuitry of reading in men with nonsyndromic clefts of the lip or palate. The Cleft Palate-Craniofacial Journal, 43, 683690. doi: 10.1597/05-043.

Gourion, D., Goldberger, C., Bourdel, M.-C., Bayle, F.J., Loo, H. \& Krebs, M.-O. (2004). Minor physical anomalies in patients with schizophrenia and their parents: Prevalence and pattern of craniofacial abnormalities. Psychiatric Research, 125, 21-28. doi: 10.1016/j.psychres.2003.06.001.

Gussy, M. \& Kilpatrick, N. (2006). The self-concept of adolescents with cleft lip and palate: A pilot study using a multidimensional/hierarchical measurement instrument. International Journal of Pediatric Dentistry, 16, 335341. doi: 10.1111/j.1365-263X.2006.00754.x.

Ha, P., Zhuge, X.-Q., Zheng, Q., Shi, B., Gong, C.-X. \& Wang, Y. (2013). Behavioral pattern in Chinese schoolaged children with cleft lip and palate. Asian Pacific Journal of Tropical Medicine, 6, 162-166. doi: 10.1016/S1995-7645(13)60016-4.

Hall, M.J., Gibson, B.J., James, A. \& Rodd, H.D. (2012). Children's experiences of participation in the cleft lip and palate care pathway. International Journal of Paediatric Dentistry, 22, 442-450. doi: 10.1111/j.1365263X.2011.01214.x.

Hall, M.J., Gibson, B.J., James, A. \& Rodd, H.D. (2013). Children's and adolescents' perspectives on cleft lip and/or palate. The Cleft Palate-Craniofacial Journal, 50, e18-e26. doi: 10.1597/10-193.

Halliwell, E. (in press). Future directions of positive body image research. Body Image, in press. doi: 10.1016/j.bodyim.2015.03.003.

Hamlet, C. \& Harcourt, D. (2015). Older adults' experiences of living with cleft lip and palate: A qualitative study exploring aging and appearance. The Cleft Palate-Craniofacial Journal, 52, e32-e40. doi: 10.1597/13-308.

Havstam, C., Laakso, K., Lohmander, A. \& Ringsberg, K.C. (2011). Taking charge of communication: Adults' descriptions of growing up with a cleft-related speech impairment. The Cleft Palate-Craniofacial Journal, 48, 717-726. doi: 10.1597/10-033.

Havstam, C., Laakso, K. \& Ringsberg, K.C. (2011). Making sense of the cleft: Young adults' accounts of growing up with a cleft and deviant speech. Journal of Health Psychology, 16, 22-30. doi: $10.1177 / 1359105310367529$.

Havstam, C., Sandberg, A.D. \& Lohmander, A. (2011). Communication attitude and peech in 10-year-old children with a cleft (lip and) palate: An ICF perspective. International Journal of Speech-Language Pathology, 13, 156-164. doi: 10.3109/17549507.2011.514946. 
Hens, G., Picavet, V.A., Vander Poorten, V., Schoenaers, J., Jorissen, M. \& Hellings, P.W. (2011). High patients satisfaction after secondary rhinoplasty in cleft lip patients. International Forum of Allergy \& Rhinology, 1, 167172. doi: 10.1002/alr.20023.

Hentges, F., Hill, J., Bishop, D.V.M., Goodacre, T., Moss, T. \& Murray, L. (2011). The effect of cleft lip on cognitive development in school-aged children: A paradigm for examining sensitive period effects. Journal of Child Psychology and Psychiatry, 52, 704-712. doi: 10.1111/j.1469-7610.2011.02375.

Hunt, O., Burden, D., Hepper, P. \& Johnston, C. (2005). The psychosocial effects of cleft lip and palate: A systematic review. European Journal of Orthodontics, 27, 274-285. doi: 10.1093/ejo/cji004.

Hunt, O., Burden, D., Hepper, P., Stevenson, M. \& Johnston, C. (2006). Self-reports of psychosocial functioning among children and young adults with cleft lip and palate. The Cleft Palate-Craniofacial Journal, 43, 598-605. doi: $10.1597 / 05-080$.

Hunt, O., Burden, D., Hepper, P., Stevenson, M. \& Johnston, C. (2007). Parent reports of the psychosocial functioning of children with cleft lip and/or palate. The Cleft Palate-Craniofacial Journal, 44, 304-311. doi: 10.1597/05-205.

Klassen, A.F., Tsangaris, E., Forrest, C.R., Wong, K.W.Y., Pusic, A.L., Cano, S.J., Syed, I., Dua, M., Kainth, S., Johnson, J. \& Goodacre, T. (2012). Quality of life of children treated for cleft lip and/or palate: A systematic review. Journal of Plastic, Reconstructive \& Aesthetic Surgery, 65, 547-557. doi: 10.1016/j.bjps.2011.11.004.

Klinto, K., Salameh, E.-K. \& Lohmander, A. (2015). Verbal competence in narrative retelling in 5-year-olds with unilateral cleft lip and palate. International Journal of Language \& Communication Disorders, 50, 119128. doi: 10.1111/1460-6984.12127.

Knight, J., Cassell, C.H., Meyer, R.E. \& Strauss, R.P. (2015). Academic outcomes of children with isolated orofacial clefts compared with children without a major birth defect. The Cleft Palate-Craniofacial Journal, 52 , 259-268. doi: 10.1597/13-293.

Kramer, F.-J., Gruber, R., Fialka, F., Sinikovic, B., Hahn, W. \& Schliephake, H. (2009). Quality of life in school-age children with orofacial clefts and their families. Journal of Craniofacial Surgery, 20, 2061-2066.

Kramer, F.-J., Gruber, R., Fialka, F., Sinikovic, B. \& Schliephake, H. (2008). Quality of life and family functioning in children with nonsyndromic orofacial clefts at preschool ages. The Journal of Craniofacial Surgery, 19, 580-587. doi: 10.1097/SCS.0b013e31816aaa43.

Krikken, J.B., de Jongh, A., Veerkamp, J.S.J., Vogels, W., ten Cate, J.M. \& van Wijk, A.J. (2015). Longitudinal changes in dental fear and coping behaviour in children, adolescents and young adults with cleft lip and/or cleft palate. The Cleft Palate-Craniofacial Journal, 52, e73-e80. doi: 10.1597/12-262

Laasonen, M., Haapanen, M.-L., Maenpaa, P., Pulkkinen, J., Ranta, R. \& Virsu, V. (2004). Visual, auditory and tactile temporal processing in children with oral clefts. The Journal of Craniofacial Surgery, 15, 511-518.

Landsberger, P., Proff, P., Dietze, S., Hoffmann, A., Kaduk, W., Meyer, F.-U. \& Mack, F. (2006). Evaluation of patient satisfaction after therapy of unilateral clefts of lip, alveolus and palate. Journal of Cranio-Maxillofacial Surgery, 34, S31-33.

Lee, K.S.M., Young, S.E.-L., Liow, S.J.R. \& Purcell, A.A. (2015). Spelling processes of children with nonsyndromic cleft lip and/or palate: A preliminary study. The Cleft Palate-Craniofacial Journal, 52, 70-81. doi: 10.1597/13-120.

Liddle, M.J., Baker, S.R., Smith, K.G. \& Thompson, A.R. (2015). Psychosocial outcomes in orthognathic surgery: A review of the literature. The Cleft Palate-Craniofacial Journal, 52, 458-470. doi: 10.1597/14-021.

Lima, L.S., Ribeiro, G.S., de Aquino, S.N., Volpe, F.M., Martelli, D.R.B., Swerts, M.S.O., Paranaiba, L.M.R., Martelli Junior, H. (2015). Prevalence of depressive symptoms in patients with cleft lip and palate. Brazilian Journal of Otorhinolaryngology, 81, 177-183. doi: 10.1016/j.bjorl.2015.01.004.

Lorot-Marchand, A., Guerreschi, P., Pellerin, P., Martinot, V., Gbaguidi, C.C., Neiva, C., Devauchelle, B., Frochisse, C., Poli-Merol, M.L. \& Francois-Fiquet, C. (2015). Frequency and socio-psychological impact of taunting in school-age patients with cleft lip-palate surgical repair. International Journal of Pediatric Otorhinolaryngology, 79, 1041-1048. doi: 10.1016/j.ijporl.2015.04.024. 
Luoto, A., Lahti, S., Nevanpera, T., Tolvanen, M. \& Locker, D. (2008). Oral-health-related quality of life among children with and without dental fear. International Journal of Paediatric Dentistry, 19, 115-120. doi: 10.1111/j.1365-263X.2008.00943.x.

Mani, M., Carlsson, M. \& Marcusson, A. (2010). Quality of life varies with gender and age among adults treated for unilateral cleft lip and palate. The Cleft Palate-Craniofacial Journal, 47, 491-498. doi: 10.1597/08-281.

Mani, M., Reiser, E., Andlin-Sobocki, A., Skoog, V. \& Holmström, M. (2013). Factors related to quality of life and satisfaction with nasal appearance in patients treated for unilateral cleft lip and palate. The Cleft PalateCraniofacial Journal, 50, 432-439. doi: 10.1597/11-035.

Meyer-Marcotty, P., Alpers, G.W., Gerdes, A.B.M. \& Stellzig-Eisenhauer, A. (2010). Impact of facial asymmetry in visual perception: A 3-deimensional data analysis. American Journal of Orthodontics and Dentofacial Orthopedics, 137, 168.e1-168.e8. doi: 10.1016/j.ajodo.2008.11.023.

Meyer-Marcotty, P., Gerdes, A.B.M., Reuther, G.T., Stellzig-Eisenhauer, A. \& Alpers, G.W. (2010). Persons with cleft lip and palate are looked at differently. Journal Dental Research, 89, 400-404. doi; 10.1177/0022034509359488.

Meyer-Marcotty, P., Gerdes, A.B.M., Stellzig-Eisenhauer, A. \& Alpers, G.W. (2011). Visual face perception of adults with unilateral cleft lip and palate in comparison to controls - An eye-tracking study. The Cleft PalateCraniofacial Journal, 48, 210-216. doi: 10.1597/08-244.

Meyer-Marcotty, P., Kochel, J., Boehm, H., Linz, C., Klammert, U. \& Stellzig-Eisenhauer, A. (2011). Face perception in patients with unilateral cleft lip and palate and patients with severe Class III malocclusion compared to controls. Journal of Cranio-Maxillo-Facial Surgery, 39, 158-163. doi: 10.1016/j.jcms.2010.05.001.

Meyer-Marcotty, P. \& Stellzig-Eisenhauer, A. (2009). Dentofacial self-perception and social perception of adults with unilateral cleft lip and palate. Journal of Orofacial Orthopedics, 70, 224-236. doi: 10.1007/s00056-0098813-9.

Millar, K., Bell, A., Bowman, A., Brown, D., Lo, T.-W., Siebert, P., Simmons, D. \& Ayoub, A. (2013). Psychological status as a function of residual scarring and facial asymmetry after surgical repair of cleft lip and palate. The Cleft Palate-Craniofacial Journal, 50, 150-157. doi: 10.1597/10-222.

Montirosso, R., Fedeli, R., Murray, L., Morandi, F., Brusati, R., Perego, G.G. \& Borgatti, R. (2012). The role of negative maternal affective states and infant temperament in early interactions between infants with cleft lip and their mothers. Journal of Pediatric Psychology, 37, 241-250. doi: 10.1093/jpepsy/jsr089.

Munz, S.M., Edwards, S.P. \& Inglehart, M.R. (2011). Oral health-related quality of life and satisfaction with treatment and treatment outcomes of adolescents/young adults with cleft lip/palate: An exploration. International Journal of Oral and Maxillofacial Surgery, 40, 790-796. doi: 10.1016/j.ijom.2011.03.002.

Murray, L., Arteche, A., Bingley, C., Hentges, F., Bishop, D.V.M., Dalton, L., Goodacre, T., Hill, J. and the Cleft Lip and Palate Study team (2010). The effect of cleft lip on socio-emotional functioning in school-aged children. The Journal of Child Psychology and Psychiatry, 51, 94-103. doi: 10.1111/j.1469-7610.2009.02186.x.

Murray, L., Hentges, F, Hill, J., Karpf, J., Mistry, B., Kreutz, M., Woodall, P., Moss, T., Goodacre, T. and the Cleft Lip and Palate Study team (2008). The effect of cleft lip and palate and the timing of lip repair on motherinfant interactions and infant development. The Journal of Child Psychology and Psychiatry, 49, 115-123. doi: 10.1111/j.1469-7610.2007.01833.x.

Nelson, P. (2009). Qualitative approaches in craniofacial research. The Cleft Palate-Craniofacial Journal, 46, 245-251. doi: 10.1597/08-121.1.

Nelson, P., Glenny A.-M., Kirk, S. \& A.-L. Caress (2012). Parents' experiences of caring for a child with a cleft lip and/or palate: A review of the literature. Child: Care, Health and Development, 38, 6-20. doi: 10.1111/j.1365-2214.2011.01244.x.

Nkenke, E., Stelzle, F., Vairaktaris, E. \& Knipfer, C. (2013). Do cleft lip and palate patients opt for secondary corrective surgery of upper lip and nose frequently? Head \& Face Medicine, 9. doi: 10.1186/1746-160X-9-38.

Noor, S.N.F.M. \& Musa, S. (2006). Assessment of patients' level of satisfaction with cleft treatment using the Cleft Evaluation Profile. The Cleft Palate Craniofacial Journal, 44, 292-303. doi: 10.1597/05-151. 
Nopoulos, P., Boes, A.D., Jabines, A., Conrad, A.L., Canady, J., Richman, L. \& Dawson, J.D. (2010). Hyperactivity, impulsivity and inattention in boys with cleft lip and palate: Relationship to ventromedial prefrontal cortex morphology. Journal of Neurodevelopmental Disorders, 2, 235-242. doi: 10.1007/s11689-0109060-5.

Nopoulos, P., Choe, I., Berg, S., van Demark, D., Canady, J. \& Richman, L. (2005). Ventral frontal cortex morphology in adult males with isolated orofacial clefts: Relationship to abnormalities in social function. The Cleft Palate-Craniofacial Journal, 42, 138-144. doi: 10.1597/03-112.1.

Nopoulos, P., Langbehn, D.R., Canady, J., Magnotta, V. \& Richman, L. (2007). Abnormal brain structure in children with isolated clefts of the lip or palate. Archives of Pediatrics \& Adolescent Medicine, 161, $753-758$. doi: 10.1001/archpedi.161.8.753.

O’Hanlon, K., Camic, P.M. \& Shearer, J. (2012). Factors associated with parental adaptation to having a child with a cleft lip and/or palate: The impact of parental diagnosis. The Cleft Palate-Craniofacial Journal, 49, 718729. doi: 10.1597/10-018.

Oosterkamp, B.C.M., Dijkstra, P.U., Remmelink, H.J., van Oort, R.P., Goorhuis-Brouwer, S.M., Sandham, A. \& de Bont, L.G.M. (2007). Satisfaction with treatment outcome in bilateral cleft lip and palate patients. International Journal of Oral and Maxillofacial Surgery, 36, 890-895. doi: 10.1016/j.ijom.2007.07.008.

Papamanou, D.A., Gkantidis, N., Topouzelis, N. \& Christou, P. (2012). Appreciation of cleft lip and palate treatment outcome by professionals and laypeople. European Journal of Orthodontics, 34, 553-560. doi: 10.1093/ejo/cjr073.

Pausch, N.C., Winter, K., Halama, D., Wirtz, C., Yildirim, V. \& Nattapong, S. (in press). Psychosocial acceptance of cleft patients: Has something changed? Journal of Oral and Maxillofacial Surgery, in press. doi: 10.1007/s10006-015-0518-1.

Pavia, T.S. \& Andre, M. (2012). Evaluating aesthetics of the nasolabial region in children with cleft lip and palate: Professional analysis and patient satisfaction. Patient Preference and Adherence, 6, 781-787. doi: 10.2147/PPA.S36656.

Persson, M., Becker, M. \& Svensson, H. (2007). Physical characteristics of young men with cleft lip, with or without cleft palate, and cleft palate only. Scandinavian Journal of Plastic and Reconstructive Surgery and Hand Surgery, 41, 6-9.

Persson, M., Becker, M. \& Svensson,H. (2008). General intellectual capacity of young men with cleft lip with or without cleft palate alone. Journal of Plastic and Reconstructive Surgery and Hand Surgery, 42, 14-16. doi: 10.1080/02844310701694472.

Persson, M., Becker, M. \& Svensson, H. (2012). Academic achievement in individuals with cleft: A populationbased register study. The Cleft Palate-Craniofacial Journal, 49, 153-159. doi: 10.1597/09-047.

Petráčková, I., Zach, J., Borský, J., Černý, M., Hacklová, R., Tvrdek, M. \& Janota, J. (2015). Early and late operation of cleft lip and intelligence quotient and psychosocial development in 3-7 years. Early Human Development, 91, 149-152. doi: 10.1016/j.earlhumdev.2014.12.015.

Pisula, E., Lukowska, E. \& Fudalej, P.S. (2014). Self-esteem, coping styles and quality of life in Polish adolescents and young adults with unilateral cleft lip and palate. The Cleft Palate-Craniofacial Journal, 51, 290299. doi: 10.1597/13-002.

Pitak-Arnnop, P., Hemprich, A., Dhanuthai, K., Yildirim, V. \& Pausch, N.C. (2011). Panel and patient perceptions of nasal aesthetics after secondary cleft rhinoplasty with versus without columellar grafting. Journal of Cranio-Maxillo-Facial Surgery, 39, 319-325. doi: 10.1016/j.jcms.2010.07.007.

Queiroz Herkrath, A.P., Herkrath, F.J., Rebelo, M.A. \& Vettore, M. V. (2015). Measurement of helath-related and oral health-related quality of life among individuals with nonsyndromic orofacial clefts: A systematic review and meta-analysis. The Cleft Palate-Craniofacial Journal, 52, 157-172. doi: 10.1597/13-104.

Ranganathan, K., Vercler, C.J., Warscausky, S.A., MacEachern, M.P., Buchman, S.R. \& Waljee, J.F. (2015). Comparative effectiveness studies examining patient-reported outcomes among children with cleft lip and/or palate: A systematic review. Plastic and Reconstructive Surgery, 135, 198-211. doi: 10.1097/PRS.0000000000000825. 
Reekie, T. (2011). The effect of South Asian ethnicity on satisfaction with primary cleft lip and palate repair. Journal of Plastic, Reconstructive \& Aesthetic Surgery, 64, 189-194. doi: 10.1016/j.bjps.2010.04.012.

Richman, L.C., McCoy, T.E., Conrad, A.L. \& Nopoulos, P.C. (2012). Neuropsychological, behavioural and academic sequelae of cleft: Early developmental, school age and adolescent/young adult outcomes. The Cleft Palate-Craniofacial Journal, 49, 387-396. doi: 10.1597/10-237.

Richman, L.C., Ryan, S., Wilgenbusch, T. \& Millard, T. (2004). Overdiagnosis and medication for AttentionDeficit Hyperactivity Disorder in children with cleft: Diagnostic examination and follow-up. The Cleft PalateCraniofacial Journal, 41, 351-354. doi: 10.1597/03-047.1.

Richman, L.C., Wilgenbusch, T. \& Hall, T. (2005). Spontaneous verbal labelling: Visual memory and reading ability in children with cleft. The Cleft Palate-Craniofacial Journal, 42, 565-569. doi: 10.1597/04-128R.1.

Ruiter, J.S., Korsten-Meijer, A.G.W. \& Goorhuis-Brouwer, S.M. (2009). Communicative abilities in toddlers and in early school age children with cleft palate. International Journal of Pediatric Otorhinolaryngology, 73, 693-698. doi: 10.1016/j.ijporl.2009.01.006.

Rumsey, N. \& Harcourt, D. (eds, 2005). The Psychology of Appearance. Berkshire: Open University Press.

Rumsey, N. \& Harcourt, D. (eds, 2012). The Oxford Handbook of the Psychology of Appearance. Oxford: Oxford University Press.

Sagheri, D., Ravens-Sieberer, U., Braumann, B. \& von Mackensen, S. (2009). An evaluation of health-related quality of life (HRQoL) in a group of 4-7 year-old children with cleft lip and palate. Journal of Orofacial Orthopedics, 70, 274-284. doi: 10.1007/s00056-009-9906-1.

Sàndor, G.K.B. \& Ylikontiola, L.P. (2006). Patient evaluation of outcomes of external rhinoplasty for unilateral cleft lip and palate. International Journal of Maxillofacial Surgery, 35, 407-411. doi:

10.1016/j.ijom.2006.01.020.

Scherer, N.J., Williams, A.L. \& Proctor-Williams, K. (2008). Early and later vocalization skills in children with and without cleft palate. International Journal of Pediatric Otorhinolaryngology, 72, 827-840. doi: 10.1016/j.ijporl.2008.02.010.

Scheuerle, J., Guilford, A.M. \& Habal, M.B. (2004). A report of behavioural data on three groups of patients with craniofacial disorders. The Journal of Craniofacial Surgery, 15, 201-208.

Seaton, C.L. (2009). Psychological adjustment. In: S.J. Lopez, The Encyclopedia of Positive Psychology. West Sussex, UK: Blackwell Publishing.

Semb, G. (2014). International confederation for cleft lip and palate and related craniofacial anomalies task force report: Beyond Eurocleft. The Cleft Palate-Craniofacial Journal, 51, e146-155. doi: 10.1597/14-120.

Semb, G., Brattstrōm, V., Mølsted, K., Prahl-Andersen, B., Zuurbier, P., Rumsey, N. \& Shaw, W.C. (2005). The Eurocleft Study: Intercenter study of treatment outcome in patients with complete cleft lip and palate. Part 4: Relationship among treatment outcome, patient/parent satisfaction and the burden of care. The Cleft PalateCraniofacial Journal, 42, 83-92. doi: 10.1597/02-119.4.1.

Sharp, H.M., Canady, J.W., Ligot, F.A.C., Hague, R.A., Gutierrez, J. \& Gutierrez, J. (2008). Caregiver and patient reported outcomes after repair of cleft lip and/or palate in the Philippines. The Cleft Palate-Craniofacial Journal, 45, 163-171. doi: 10.1597/06-230.1.

Shriver, A.S., Canady, J., Richman, L., Andreasen, N.C. \& Nopoulos, P. (2006). Structure and function of the superior temporal plane in adult males with cleft lip and palate: Pathologic enlargement with no relationship to childhood hearing deficits. Journal of Child Psychology and Psychiatry, 47, 994-1002. doi: 10.1111/j.14697610.2006.01679.x.

Sinko, K., Jagsch, R., Prechtl, V., Watzinger, F., Hollmann, K. \& Baumann, A. (2005). Evaluation of esthetic, functional and quality-of-life outcome in adult cleft lip and palate patients. The Cleft Palate-Craniofacial Journal, 42, 355-361. doi: 10.1597/03-142.1.

Slifer, K.J., Amari, A., Diver, T., Hilley, L., Beck, M., Kane, A. \& McDonnell, S.A. (2004). Social interaction patterns of children and adolescents with and without oral clefts during a videotaped analogue social encounter. The Cleft Palate-Craniofacial Journal, 41, 175-184. doi: 10.1597/02-084. 
Slifer, K.J., Pulbrook, V., Amari, A., Vona-Messersmith, N., Cohn, J.F., Ambadar, Z., Beck, M. \& Piszczor, R. (2006). Social acceptance and facial behaviour in children with oral clefts. The Cleft Palate-Craniofacial Journal, 43, 226-236. doi: 10.1597/05-018.1.

Smillie, I., Yong, K., Harris, K., Wynee, D.M. \& Russell, C.J. (2015). Socioeconomic influence on orofacial cleft patient care. Scottish Medical Journal, 60, 70-74. doi: 10.1177/0036933014564133.

Smith, C.B., Walker, K., Badawi, N., Waters, K.A., MacLean, J.E. (2014). Impact of sleep and breathing in infancy on outcomes at three years of age for children with cleft lip and/or palate. SLEEP, 37, 919-925. doi: 10.5665/sleep.3660.

Smolak, L. (2004). Body image in children and adolescents: where do we go from here? Body Image, 1, 15-28.

Snyder, H. \& Pope, A.W. (2010). Psychosocial adjustment in children and adolescents with a craniofacial anomaly: Diagnosis-specific patterns. The Cleft Palate-Craniofacial Journal, 47, 264-272. doi: 10.1597/08227.1 .

Stock, N.M., Feragen, K.B. \& Rumsey, N. (2015). “It doesn't all just stop at 18”: Psychological adjustment and support needs of adults born with cleft lip and/or palate. The Cleft Palate-Craniofacial Journal, 52, 543-554. doi: $10.1597 / 14-178$.

Stock, N.M., Hammond, V., Owen, T., Kiff, J., Shanly, A. \& Rumsey, N. (in press), Achieving consensus in the measurement of psychological adjustment to cleft lip and/or palate. The Cleft Palate-Craniofacial Journal, in press. doi: 10.1597/15-071.

Stock, N.M., Feragen, K.B. \& Rumsey, N. (in press). Adults' narratives of growing up with a cleft lip and/or palate: Factors associated with psychological adjustment. The Cleft Palate-Craniofacial Journal, in press. doi: 10.1597/14-269.

Stock, N.M. \& Rumsey, N. (2015). Starting a family: The experience of parents with cleft lip and/or palate. The Cleft Palate-Craniofacial Journal, 52, 425-436. doi: 10,1597/13-314.

Strauss, R.P. (2001). "Only skin deep": Health, resilience and craniofacial care. The Cleft Palate-Craniofacial Journal, 38, 226-230. doi: 10.1597/1545-1569.

Tiemens, K., Nicholas, D. \& Forrest, C.R. (2013). Living with difference: Experiences of adolescent girls with cleft lip and palate. The Cleft Palate-Craniofacial Journal, 50, e27-e34. doi: 10.1597/10-278.

Tierney, S., O’Brien, K., Harman, N.L., Sharma, R.K., Madden, C. \& Callery, P. (2015). Otitis Media with Effusion: Experiences of children with cleft palate and their parents. The Cleft Palate-Craniofacial Journal, 52 , 23-30. doi: 10.1597/13-139.

Tyler, M.C., Wehby, G.L., Robbins, J.M. \& Damiano, P.C. (2013). Separation anxiety in children ages 4 through 9 with oral clefts. The Cleft Palate-Craniofacial Journal, 50, 520-527. doi: 10.1597/11-239.

van der Plas, E., Conrad, A., Canady, J., Richman, L. \& Nopoulos, P. (2010). Effects of unilateral clefts on brain structure. Archives of Pediatrics and Adolescent Medicine, 164, 763-768. doi: 10.1001/archpediatrics.2010.123.

van Lierde, K.M., Dhaeseleer, E., Luyten, A., van de Woestljne, K., Vermeersch, H. \& Roche, N. (2012). Parent and child ratings of satisfaction with speech and facial appearance in Flemish pre-pubescent boys and girls with unilateral cleft lip and palate. International Journal of Oral and Maxillofacial Surgery, 41, 192-199. doi: 10.1016/j.ijom.2011.10.030.

van Schijndel, O., Litschel, R., Maal, T.J.J., Bergé, S.J. \& Tasman, A.-J. (in press). Eye tracker based study: Perception of faces with a cleft lip and nose deformity. Journal of Cranio-Maxillo-Facial Surgery, in press. doi: 10.1016/j.jcms.2015.07.003.

Versnel, S.L., Duivenvoorden, H.J., Passchier, J. \& Mathijssen, I.M.J. (2010). Satisfaction with facial appearance and its determinants in adults with severe congenital facial disfigurement: A case-referent study. Journal of Plastic, Reconstructive \& Aesthetic Surgery, 63, 1642-1649. doi: 10.1016/j.bjps.2009.10.018.

Vogels, W.E.J.C., Aartman, I.H.A. \& Veerkamp, J.S.J. (2011). Dental fear in children with a cleft lip and/or cleft palate. The Cleft Palate-Craniofacial Journal, 48, 736-740. doi: 10.1597/09-041. 
Watterson, T., Macini, M.C., Brancamp, T.U. \& Lewis, K.E. (2013). .Relationship between the perception of hypernasality and social judgments in school-aged children. The Cleft Palate-Craniofacial Journal, 50, 498-502. doi: $10.1597 / 11-126$.

Wehby, G.L. \& Cassell, C.H. (2010). The impact of orofacial clefts on quality of life and healthcare use and costs. Oral Diseases, 16, 3-10. doi: 10.1111/j.1601-0825.2009.01588.x.

Wehby, G.L., Collett, B., Barron, S., Romitti, P.A., Ansley, T.N. \& Speltz, M. (2014). Academic achievement of children and adolescents with oral clefts. PEDIATRICS, 133, 785-792. doi: 10.1542/peds.2013-3072.

Wehby, G.L., Nyarko, K.A. \& Murray, J.C. (2014). Oral cleft recurrence risk and subsequent maternal fertility preferences and behavior in Brazil. Birth Defects Research, 100, 48-56. doi: 10.1002/bdra.23214.

Wehby, G.L., Tyler, M.C., Lindgren, S., Romitti, P., Robbins, J. \& Damiano, P. (2012). Oral clefts and behavioural health of young children. Oral Diseases, 18, 74-84. doi: 10.1111/j.1601-0825.2011.01847.x.

World Health Organization (2012). Oral Health (Fact Sheet No. 318). Retrieved from http://www.who.int/mediacentre/factsheets/fs318/en.

Yazdy, M.M., Honein, M.A., Rasmussen, S.A. \& Frias, J.L. (2007). Priorities for future public health research in orofacial clefts. The Cleft Palate-Craniofacial Journal, 44, 351-357. doi: 10.1597/06-233.1.

Young, S.E.-L., Purcell, A.A. \& Ballard, K.J. (2010). Expressive language skills in Chinese Singaporean preschoolers with nonsyndromic cleft lip and/or palate. International Journal of Pediatric Otorhinolaryngology, 74, 456-464. doi: 10.1016/j.ijporl.2010.01.014.

Young, S.E.-L., Purcell, A.A., Ballard, K.J., Liow, S.J.R., Ramos, S.dS. \& Heard, R. (2012). Bilingual children with nonsyndromic cleft lip and/or palate: Language and memory skills. Journal of Speech, Language and Hearing Research, 55, 1314-1328. doi: 10.1044/1092-4388.

Yttri, J.E., Christensen, K., Knudsen, L.B. \& Bille, C. (2011). Reproductive patterns among Danish women with oral clefts. The Cleft Palate-Craniofacial Journal, 48, 601-607. doi: 10.1597/09-245.

Yunusa, M.A. \& Obembe, A. (2013). Prevalence of psychiatric morbidity using GHQ-28 among cleft lip patients in Sokoto. Annals of African Medicine, 12, 135-139. doi: 10.4103/1596-3519.112414.

Zeytinoglu, S. \& Davey, M.P. (2012). It's a privilege to smile: Impact of cleft lip/palate on families. Families, Systems \& Health, 30, 265-277. doi: 10.1037/a0028961.

Zhu, S., Jayaraman, J. \& Khambay, B. (in press). Evaluation of facial appearance in patients with cleft lip and palate by laypeople and professionals: A systematic literature review. The Cleft Palate-Craniofacial Journal, in press. doi: 10.1597/14-177. 
*SUPPLEMENTARY FILE*

Figure 1: Flow chart demonstrating the selection of articles for inclusion in this review.

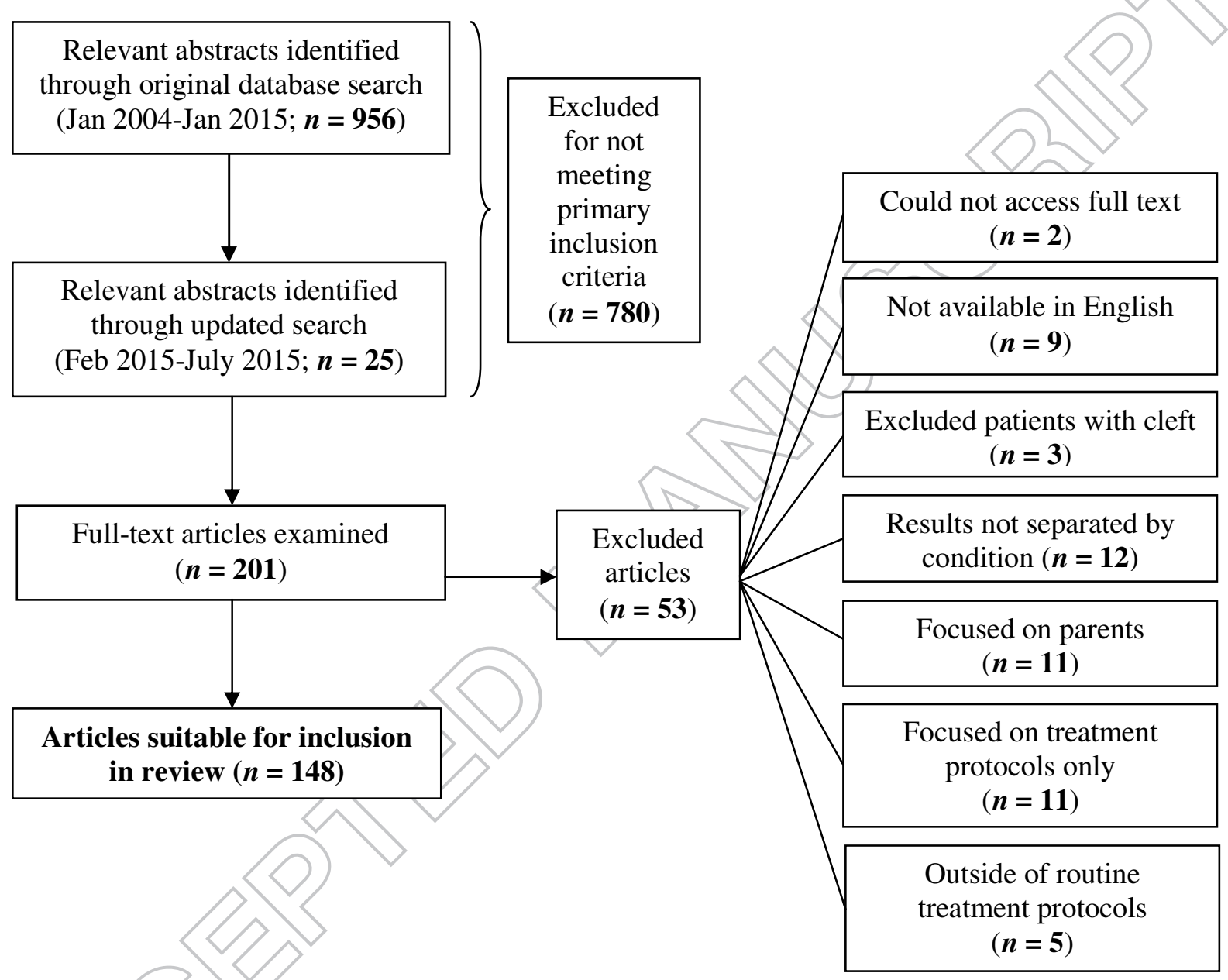


*SUPPLEMENTARY FILE*

Table 1: Search terms used in this review.

\begin{tabular}{|c|c|c|c|c|c|c|}
\hline Diagnosis & Population & $\begin{array}{l}\text { Developmental } \\
\text { Trajectory }\end{array}$ & Behaviour & $\begin{array}{l}\text { Emotional } \\
\text { Wellbeing }\end{array}$ & $\begin{array}{l}\text { Social } \\
\text { Experiences }\end{array}$ & $\begin{array}{l}\text { Appearance } \\
\text { and } \\
\text { Treatment }\end{array}$ \\
\hline $\begin{array}{l}\text { Cleft } \\
\text { Cleft lip and } \\
\text { palate } \\
\text { Cleft } \\
\text { lip/palate } \\
\text { CLP } \\
\text { CL/P } \\
\text { Craniofac* } \\
\text { Visible } \\
\text { difference } \\
\text { Disfigure* } \\
\text { Impair* }\end{array}$ & $\begin{array}{l}\text { Parent* } \\
\text { Maternal } \\
\text { Famil* } \\
\text { Child* } \\
\text { Adolesc* } \\
\text { Adult }\end{array}$ & $\begin{array}{l}\text { Cognit* } \\
\text { Learn* } \\
\text { School } \\
\text { Achieve* } \\
\text { Language } \\
\text { Memory } \\
\text { Intelligen* } \\
\text { IQ } \\
\text { Develop* } \\
\text { Speech } \\
\text { Health }\end{array}$ & $\begin{array}{l}\text { Behaviou* } \\
\text { Attention } \\
\text { Hyperactivity } \\
\text { Internal* } \\
\text { External* }\end{array}$ & $\begin{array}{l}\text { Psych* } \\
\text { Impact } \\
\text { Effect } \\
\text { Adjust* } \\
\text { Experience } \\
\text { Emotion* } \\
\text { Affect } \\
\text { Stress } \\
\text { Depress* } \\
\text { Anx* } \\
\text { Stigma } \\
\text { Cop* } \\
\text { Distress } \\
\text { Quality of } \\
\text { life } \\
\text { QoL } \\
\text { Self* } \\
\text { Resilien* }\end{array}$ & $\begin{array}{l}\text { Social } \\
\text { Peer } \\
\text { Friend* } \\
\text { Intima* } \\
\text { Attach* }\end{array}$ & $\begin{array}{l}\text { Treatment } \\
\text { Surg* } \\
\text { Pathway } \\
\text { Satisfaction } \\
\text { Function } \\
\text { Rating } \\
\text { Outcome } \\
\text { Body Image } \\
\text { Appearance }\end{array}$ \\
\hline
\end{tabular}

* denotes unlimited truncation which retrieves all possible suffix variations of a root word. 
*SUPPLEMENTARY FILE*

Table 2: Categorisation of findings according to five key domains of adjustment.

\begin{tabular}{|c|c|c|c|c|}
\hline $\begin{array}{l}\text { Developmental } \\
\text { Trajectory }\end{array}$ & Behaviour & $\begin{array}{l}\text { Emotional } \\
\text { Wellbeing }\end{array}$ & $\begin{array}{l}\text { Social } \\
\text { Experiences }\end{array}$ & $\begin{array}{l}\text { Satisfaction with } \\
\text { Appearance and } \\
\text { Treatment }\end{array}$ \\
\hline $\begin{array}{l}\text { General health } \\
\text { Associated } \\
\text { conditions } \\
\text { Neurological } \\
\text { aspects } \\
\text { Cognitive } \\
\text { development } \\
\text { Language } \\
\text { development } \\
\text { Educational } \\
\text { experiences } \\
\text { Employment }\end{array}$ & $\begin{array}{l}\text { Behavioural } \\
\text { conduct } \\
\text { Internalising/ } \\
\text { externalising } \\
\text { behaviours } \\
\text { Inattention/ } \\
\text { hyperactivity }\end{array}$ & $\begin{array}{l}\text { Psychiatric } \\
\text { conditions } \\
\text { Emotional } \\
\text { functioning } \\
\text { Self-concept }\end{array}$ & $\begin{array}{l}\text { Parent-child } \\
\text { relationships } \\
\text { Social functioning } \\
\text { Communication } \\
\text { difficulties } \\
\text { Social reactions } \\
\text { to CL/P } \\
\text { Teasing } \\
\text { Social acceptance } \\
\text { Romantic } \\
\text { relationships }\end{array}$ & $\begin{array}{l}\text { General satisfaction } \\
\text { with appearance } \\
\text { Motivations for } \\
\text { surgical intervention } \\
\text { Experiences of } \\
\text { treatment } \\
\text { Satisfaction with } \\
\text { aesthetic and } \\
\text { functional treatment } \\
\text { outcomes }\end{array}$ \\
\hline
\end{tabular}


*SUPPLEMENTARY FILE*

Table 3: An overview of the articles included in this review.

$\mathrm{x}=$ missing data $\mathrm{V}=$ validated $\mathrm{U}=$ unvalidated $; \mathrm{B}=$ behaviour; $\mathrm{D}=$ developmental trajectory; $\mathrm{E}=$ emotional; $\mathrm{S}=$ social; $\mathrm{G}=$ general adjustment; $\mathrm{T}$ = treatment outcome

\begin{tabular}{|c|c|c|c|c|c|c|c|c|c|}
\hline $\begin{array}{l}\text { Author } \\
\text { and year }\end{array}$ & $\begin{array}{l}\text { Domai } \\
n(s) \text { of } \\
\text { adjust } \\
\text { ment }\end{array}$ & Method & $\begin{array}{l}\text { Informa } \\
\text { nt(s) }\end{array}$ & $\begin{array}{l}\text { Sample } \\
\text { size }\end{array}$ & $\begin{array}{l}\text { Age } \\
\text { rang } \\
\text { e }\end{array}$ & $\begin{array}{l}\text { Compa } \\
\text { rison } \\
\text { group }\end{array}$ & $\begin{array}{l}\text { Recruitm } \\
\text { ent sites }\end{array}$ & $\begin{array}{l}\text { Exclusio } \\
\text { n criteria }\end{array}$ & $\begin{array}{l}\text { Measu } \\
\text { res }\end{array}$ \\
\hline $\begin{array}{l}\text { Gourion } \\
\text { et al. } \\
\text { (2004) }\end{array}$ & E & $\begin{array}{l}\text { Psychiatri } \\
\text { c } \\
\text { assessme } \\
\text { nts }\end{array}$ & $\begin{array}{l}\text { Professi } \\
\text { onals }\end{array}$ & $\begin{array}{l}13 \\
\text { patients } \\
+45 \\
\text { parents }\end{array}$ & $\begin{array}{l}21- \\
37 \\
\text { year } \\
\text { s }\end{array}$ & $\begin{array}{l}42 \\
\text { controls }\end{array}$ & $\begin{array}{l}\text { Single, } \\
\text { centre, } \\
\text { France }\end{array}$ & & $\begin{array}{l}\mathrm{V} \text { and } \\
\mathrm{U}\end{array}$ \\
\hline $\begin{array}{l}\text { Laasonen } \\
\text { et al. } \\
\text { (2004) }\end{array}$ & D & $\begin{array}{l}\text { Cognitive } \\
\text { assessme } \\
\text { nts }\end{array}$ & $\begin{array}{l}\text { Professi } \\
\text { onals }\end{array}$ & $\begin{array}{l}64 \\
\text { patients }\end{array}$ & $\begin{array}{l}10 \\
\text { year }\end{array}$ & & $\begin{array}{l}\text { Single } \\
\text { centre, } \\
\text { Finland }\end{array}$ & $\begin{array}{l}\text { Learning } \\
\text { difficultie } \\
\mathrm{s} ; \\
\text { difficultie } \\
\mathrm{s} \\
\text { completin } \\
\mathrm{g} \text { the } \\
\text { tasks }\end{array}$ & V \\
\hline $\begin{array}{l}\text { Richman } \\
\text { et al. } \\
\text { (2004) }\end{array}$ & $\mathrm{D}, \mathrm{B}$ & $\begin{array}{l}\text { Cognitive } \\
\text { assessme } \\
\mathrm{nt}\end{array}$ & $\begin{array}{l}\text { Professi } \\
\text { onals, } \\
\text { parents, } \\
\text { teachers }\end{array}$ & patients & $\begin{array}{l}7-12 \\
\text { year } \\
\mathrm{s}\end{array}$ & Norms & $\begin{array}{l}\text { Single } \\
\text { centre, } \\
\text { USA }\end{array}$ & $\begin{array}{l}\text { No } \\
\text { medicatio } \\
\mathrm{n}\end{array}$ & V \\
\hline $\begin{array}{l}\text { Richman } \\
\text { et al. } \\
(2005)\end{array}$ & D & $\begin{array}{l}\text { Cognitive } \\
\text { assessme } \\
\text { nts }\end{array}$ & $\begin{array}{l}\text { Professi } \\
\text { onals }\end{array}$ & $\begin{array}{l}48 \\
\text { patients }\end{array}$ & $\begin{array}{l}7-9 \\
\text { year } \\
\mathrm{s}\end{array}$ & $\begin{array}{l}\text { Norm } \\
\text { data }\end{array}$ & $\begin{array}{l}\text { Single } \\
\text { centre, } \\
\text { USA }\end{array}$ & $\begin{array}{l}\text { Syndromi } \\
\text { c cleft }\end{array}$ & V \\
\hline $\begin{array}{l}\text { Scheuerle } \\
\text { et al. } \\
\text { (2004) }\end{array}$ & $\mathrm{D}$ & $\begin{array}{l}\text { Observati } \\
\text { on }\end{array}$ & $\begin{array}{l}\text { Parents } \\
\text { and } \\
\text { professi } \\
\text { onals }\end{array}$ & $\begin{array}{l}56 \\
\text { patients }\end{array}$ & $\begin{array}{l}22- \\
30 \\
\text { mont } \\
\text { hs }\end{array}$ & None & $\begin{array}{l}\text { Single } \\
\text { centre, } \\
\text { USA }\end{array}$ & $\mathrm{x}$ & V \\
\hline $\begin{array}{l}\text { Semb et } \\
\text { al. (2005) }\end{array}$ & S, T & $\begin{array}{l}\text { Question } \\
\text { naires }\end{array}$ & $\begin{array}{l}\text { Patients, } \\
\text { parents }\end{array}$ & $\begin{array}{l}93 \\
\text { patients } \\
+82 \\
\text { parents }\end{array}$ & $\begin{array}{l}17 \\
\text { year } \\
\text { s }\end{array}$ & None & $\begin{array}{l}5 \text { centres, } \\
\text { Northern } \\
\text { Europe }\end{array}$ & $\mathrm{x}$ & $\mathrm{U}$ \\
\hline $\begin{array}{l}\text { Slifer et } \\
\text { al. (2004) }\end{array}$ & E, $S$ & $\begin{array}{l}\text { Question } \\
\text { naires; } \\
\text { observati } \\
\text { on }\end{array}$ & $\begin{array}{l}\text { Patients, } \\
\text { parents, } \\
\text { professi } \\
\text { onals }\end{array}$ & $\begin{array}{l}34 \\
\text { patients }\end{array}$ & $\begin{array}{l}8-15 \\
\text { year } \\
\text { s }\end{array}$ & $\begin{array}{l}34 \\
\text { controls }\end{array}$ & $\begin{array}{l}\text { Single } \\
\text { centre, } \\
\text { USA }\end{array}$ & 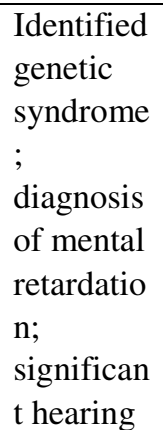 & $\mathrm{V}$ \\
\hline
\end{tabular}




\begin{tabular}{|c|c|c|c|c|c|c|c|c|c|}
\hline & & & & & & & & $\begin{array}{l}\text { impairme } \\
\text { nt; severe } \\
\text { speech } \\
\text { impairme } \\
\text { nt; full- } \\
\text { time } \\
\text { special } \\
\text { education } \\
\text { al } \\
\text { services }\end{array}$ & \\
\hline $\begin{array}{l}\text { Nopoulos } \\
\text { et al. } \\
(2005)\end{array}$ & $\mathrm{D}, \mathrm{S}$ & $\begin{array}{l}\text { Question } \\
\text { naires; } \\
\text { neuroima } \\
\text { ging }\end{array}$ & $\begin{array}{l}\text { Patients, } \\
\text { professi } \\
\text { onals }\end{array}$ & $\begin{array}{l}46 \\
\text { patients }\end{array}$ & $\begin{array}{l}18+ \\
\text { year } \\
\text { s }\end{array}$ & $\begin{array}{l}46 \\
\text { controls }\end{array}$ & $\begin{array}{l}\text { Single } \\
\text { centre, } \\
\text { USA }\end{array}$ & $\begin{array}{l}\text { Syndromi } \\
\text { c cleft } \\
\text { (van der } \\
\text { Woude } \\
\text { retained) }\end{array}$ & $\mathrm{V}$ \\
\hline $\begin{array}{l}\text { Sinko et } \\
\text { al. }(2005)\end{array}$ & E, S, T & $\begin{array}{l}\text { Question } \\
\text { naires; } \\
\text { medical } \\
\text { assessme } \\
\text { nt }\end{array}$ & $\begin{array}{l}\text { Patients, } \\
\text { professi } \\
\text { onals }\end{array}$ & $\begin{array}{l}165 \\
\text { patients }\end{array}$ & $\begin{array}{l}18- \\
30 \\
\text { year } \\
\text { s }\end{array}$ & $\begin{array}{l}\text { Norm } \\
\text { data }\end{array}$ & $\begin{array}{l}\text { Single } \\
\text { centre, } \\
\text { Austria }\end{array}$ & $\begin{array}{l}\text { Associate } \\
\text { d } \\
\text { condition } \\
\text { s }\end{array}$ & V \\
\hline $\begin{array}{l}\text { Chan et } \\
\text { al. (2006) }\end{array}$ & $\mathrm{D}$ & $\begin{array}{l}\text { Question } \\
\text { naires }\end{array}$ & $\begin{array}{l}\text { Parents, } \\
\text { teachers, } \\
\text { employe } \\
\text { rs }\end{array}$ & $\begin{array}{l}39 \\
\text { parents, } \\
27 \\
\text { teachers, } \\
37\end{array}$ & & & $\begin{array}{l}\text { Single } \\
\text { centre, } \\
\text { China }\end{array}$ & $\mathrm{x}$ & $\begin{array}{l}\mathrm{V} \text { and } \\
\mathrm{U}\end{array}$ \\
\hline $\begin{array}{l}\text { Cheung } \\
\text { et al. } \\
(2006)\end{array}$ & E, S, T & $\begin{array}{l}\text { Question } \\
\text { naires }\end{array}$ & & 9 patients & $\begin{array}{l}15- \\
40 \\
\text { year }\end{array}$ & $\begin{array}{l}9 \\
\text { controls }\end{array}$ & $\begin{array}{l}\text { Single } \\
\text { centre, } \\
\text { China }\end{array}$ & $\mathrm{x}$ & $\mathrm{V}$ \\
\hline $\begin{array}{l}\text { Damiano } \\
\text { et al. } \\
(2006)\end{array}$ & & Structure & Parents & $\begin{array}{l}151 \\
\text { mothers }\end{array}$ & $\begin{array}{l}2-12 \\
\text { year } \\
\text { s }\end{array}$ & $\begin{array}{l}85 \\
\text { mothers } \\
\text { of } \\
\text { children } \\
\text { with } \\
\text { club } \\
\text { foot }\end{array}$ & $\begin{array}{l}\text { Registry, } \\
\text { USA }\end{array}$ & $\begin{array}{l}\text { Syndromi } \\
\text { c cleft; } \\
\text { mothers } \\
\text { without } \\
\text { full } \\
\text { custody }\end{array}$ & $\mathrm{V}$ \\
\hline $\begin{array}{l}\text { Eide et al. } \\
(2006)\end{array}$ & D & $\begin{array}{l}\text { Cognitive } \\
\text { assessme } \\
\text { nt }\end{array}$ & $\begin{array}{l}\text { Professi } \\
\text { onals }\end{array}$ & $\begin{array}{l}611 \\
\text { patients }\end{array}$ & $\begin{array}{l}18 \\
\text { year } \\
\text { s }\end{array}$ & $\begin{array}{l}\text { Registry } \\
\text { data }\end{array}$ & $\begin{array}{l}\text { Registry, } \\
\text { Norway }\end{array}$ & $\mathrm{x}$ & V \\
\hline $\begin{array}{l}\text { Frederick } \\
\text { son et al. } \\
(2006)\end{array}$ & S & $\begin{array}{l}\text { Observati } \\
\text { on }\end{array}$ & $\begin{array}{l}\text { Professi } \\
\text { onals }\end{array}$ & $\begin{array}{l}17 \\
\text { patients }\end{array}$ & $\begin{array}{l}3 \\
\text { year } \\
\text { s }\end{array}$ & $\begin{array}{l}17 \\
\text { controls }\end{array}$ & $\begin{array}{l}3 \text { centres, } \\
\text { USA }\end{array}$ & $\begin{array}{l}\text { Abnorma } \\
1 \text { range of } \\
\text { cognitive } \\
\text { skills; } \\
\text { other } \\
\text { congenita } \\
1 \\
\text { anomalie } \\
\text { s; } \\
\text { neurologi }\end{array}$ & V \\
\hline
\end{tabular}




\begin{tabular}{|c|c|c|c|c|c|c|c|c|c|}
\hline & & & & & & & & $\begin{array}{l}\text { cal } \\
\text { impairme } \\
\text { nts; } \\
\text { sensorine } \\
\text { ural } \\
\text { hearing } \\
\text { loss; } \\
\text { syndromi } \\
\text { c cleft }\end{array}$ & \\
\hline $\begin{array}{l}\text { Goldsberr } \\
\text { y et al. } \\
(2006)\end{array}$ & D & $\begin{array}{l}\text { Neuroima } \\
\text { ging }\end{array}$ & $\begin{array}{l}\text { Professi } \\
\text { onals }\end{array}$ & $\begin{array}{l}8 \text { male } \\
\text { patients }\end{array}$ & $\begin{array}{l}18+ \\
\text { year } \\
\text { s }\end{array}$ & $\begin{array}{l}6 \\
\text { controls }\end{array}$ & $\begin{array}{l}\text { Single } \\
\text { centre, } \\
\text { USA }\end{array}$ & $\begin{array}{l}\text { Left- } \\
\text { handed; } \\
\text { history of } \\
\text { significan } \\
\text { t medical, } \\
\text { neurologi } \\
\text { c or } \\
\text { psychiatri } \\
\text { c illness }\end{array}$ & N/A \\
\hline $\begin{array}{l}\text { Gussy \& } \\
\text { Kilpatric } \\
\text { k (2006) }\end{array}$ & $\begin{array}{l}\mathrm{D}, \mathrm{E}, \mathrm{S}, \\
\mathrm{T}\end{array}$ & $\begin{array}{l}\text { Question } \\
\text { naire }\end{array}$ & Patients & $\begin{array}{l}23 \\
\text { patient }\end{array}$ & $\begin{array}{l}12- \\
16 \\
\text { year } \\
\mathrm{s}\end{array}$ & $\begin{array}{l}\text { Norm } \\
\text { data }\end{array}$ & $\begin{array}{l}\text { Single } \\
\text { centre, } \\
\text { Australia }\end{array}$ & $\begin{array}{l}\text { Significa } \\
\text { nt } \\
\text { medical } \\
\text { condition } \\
\text { or } \\
\text { associate } \\
\text { d } \\
\text { syndrome } \\
\text {; learning } \\
\text { disability; } \\
\text { developm } \\
\text { ental } \\
\text { delay; } \\
\text { intellectu } \\
\text { al } \\
\text { disability }\end{array}$ & $\mathrm{V}$ \\
\hline $\begin{array}{l}\text { Hunt et } \\
\text { al. (2006) }\end{array}$ & & $\begin{array}{l}\text { Question } \\
\text { naires }\end{array}$ & Patients & $\begin{array}{l}160 \\
\text { patients }\end{array}$ & $\begin{array}{l}8-21 \\
\text { year } \\
\text { s }\end{array}$ & $\begin{array}{l}113 \\
\text { controls }\end{array}$ & $\begin{array}{l}3 \text { centres, } \\
\text { UK }\end{array}$ & $\begin{array}{l}\text { Syndromi } \\
\text { c cleft; } \\
\text { learning } \\
\text { difficultie } \\
\text { s; } \\
\text { significan } \\
\text { t medical } \\
\text { history }\end{array}$ & $\begin{array}{l}\mathrm{V} \text { and } \\
\mathrm{U}\end{array}$ \\
\hline $\begin{array}{l}\text { Landsber } \\
\text { ger et al. } \\
(2006)\end{array}$ & $\mathrm{T}$ & $\begin{array}{l}\text { Question } \\
\text { naire }\end{array}$ & Patients & $\begin{array}{l}33 \\
\text { patients }\end{array}$ & $\begin{array}{l}10- \\
30+ \\
\text { year } \\
\mathrm{s}\end{array}$ & None & $\begin{array}{l}\text { Single } \\
\text { centre, } \\
\text { Germany }\end{array}$ & $\mathrm{x}$ & $\mathrm{U}$ \\
\hline $\begin{array}{l}\text { Sandor \& } \\
\text { Ylikontio } \\
\text { la (2006) }\end{array}$ & $\mathrm{T}$ & $\begin{array}{l}\text { Question } \\
\text { naires; } \\
\text { structured } \\
\text { interview }\end{array}$ & Patients & $\begin{array}{l}35 \\
\text { patients }\end{array}$ & $\begin{array}{l}16- \\
59 \\
\text { year } \\
\text { s }\end{array}$ & None & $\begin{array}{l}\text { Single } \\
\text { centre, } \\
\text { Canada }\end{array}$ & $\mathrm{x}$ & $\mathrm{U}$ \\
\hline Shriver et & $\mathrm{D}, \mathrm{E}$ & $\begin{array}{l}\text { Neuroima } \\
\text { ging; }\end{array}$ & $\begin{array}{l}\text { Patients, } \\
\text { professi }\end{array}$ & 46 male & $\begin{array}{l}18- \\
47\end{array}$ & 46 & $\begin{array}{l}\text { Single } \\
\text { centre, }\end{array}$ & $\begin{array}{l}\text { Syndromi } \\
\text { c cleft; }\end{array}$ & $\mathrm{V}$ \\
\hline
\end{tabular}




\begin{tabular}{|c|c|c|c|c|c|c|c|c|c|}
\hline al. (2006) & & \begin{tabular}{|l} 
cognitive \\
assessme \\
nts; \\
medical \\
assessme \\
nt
\end{tabular} & onals & patients & $\begin{array}{l}\text { year } \\
\mathrm{s}\end{array}$ & controls & USA & $\begin{array}{l}\text { serious } \\
\text { medical } \\
\text { or } \\
\text { psychiatri } \\
\text { c } \\
\text { condition } \\
\text {; active } \\
\text { substance } \\
\text { abuse }\end{array}$ & \\
\hline $\begin{array}{l}\text { Slifer et } \\
\text { al. (2006) }\end{array}$ & $\mathrm{S}, \mathrm{T}$ & $\begin{array}{l}\text { Observati } \\
\text { on; } \\
\text { emotional } \\
\text { response; } \\
\text { questionn } \\
\text { aires }\end{array}$ & $\begin{array}{l}\text { Patients, } \\
\text { professi } \\
\text { onals }\end{array}$ & $\begin{array}{l}24 \\
\text { patients }\end{array}$ & $\begin{array}{l}7-16 \\
\text { year } \\
s\end{array}$ & $\begin{array}{l}25 \\
\text { controls }\end{array}$ & $\begin{array}{l}\text { Single } \\
\text { centre, } \\
\text { USA }\end{array}$ & $\begin{array}{l}\text { Genetic } \\
\text { syndrome } \\
\text { with } \\
\text { mental } \\
\text { retardatio } \\
\text { n; } \\
\text { moderate } \\
\text { to severe } \\
\text { hearing } \\
\text { impairme } \\
\text { nt in both } \\
\text { ears; } \\
\text { severe } \\
\text { speech } \\
\text { impairme } \\
\text { nt; receipt } \\
\text { of full- } \\
\text { time } \\
\text { special } \\
\text { education } \\
\text { al } \\
\text { services }\end{array}$ & V \\
\hline $\begin{array}{l}\text { Boes et } \\
\text { al. (2007) }\end{array}$ & & $\begin{array}{l}\text { Question } \\
\text { naires; } \\
\text { neuroima } \\
\text { ging }\end{array}$ & $\begin{array}{l}\text { Patients, } \\
\text { parents, } \\
\text { professi } \\
\text { onals }\end{array}$ & $\begin{array}{l}33 \text { male } \\
\text { patients }\end{array}$ & $\begin{array}{l}7-12 \\
\text { year } \\
s\end{array}$ & $\begin{array}{l}43 \text { male } \\
\text { controls }\end{array}$ & $\begin{array}{l}\text { Single } \\
\text { centre, } \\
\text { USA }\end{array}$ & $\begin{array}{l}\text { Syndromi } \\
\text { c cleft; } \\
\text { medical } \\
\text { or } \\
\text { neurologi } \\
\text { cal } \\
\text { disease; } \\
\text { history of } \\
\text { learning } \\
\text { disorder } \\
\text { or } \\
\text { psychiatri } \\
\text { c disorder }\end{array}$ & V \\
\hline $\begin{array}{l}\text { Cheung } \\
\text { et al. } \\
\text { (2007) }\end{array}$ & $\mathrm{D}, \mathrm{E}, \mathrm{S}$ & $\begin{array}{l}\text { Question } \\
\text { naires }\end{array}$ & Patients & $\begin{array}{l}94 \\
\text { patients }\end{array}$ & $\begin{array}{l}10- \\
40 \\
\text { year } \\
\text { s }\end{array}$ & $\begin{array}{l}116 \\
\text { controls }\end{array}$ & $\begin{array}{l}\text { Single } \\
\text { centre, } \\
\text { China }\end{array}$ & $\mathrm{x}$ & V \\
\hline $\begin{array}{l}\text { Damiano } \\
\text { et al. } \\
\text { (2007) }\end{array}$ & $\mathrm{T}$ & $\begin{array}{l}\text { Question } \\
\text { naires; } \\
\text { structured } \\
\text { interview }\end{array}$ & Parents & $\begin{array}{l}104 \\
\text { mothers }\end{array}$ & $\begin{array}{l}2-12 \\
\text { year } \\
\mathrm{s}\end{array}$ & $\begin{array}{l}\text { Norm } \\
\text { data }\end{array}$ & $\begin{array}{l}\text { Registry, } \\
\text { USA }\end{array}$ & $\begin{array}{l}\text { Syndromi } \\
\text { c cleft; } \\
\text { mothers } \\
\text { without } \\
\text { full }\end{array}$ & $\begin{array}{l}\mathrm{V} \text { and } \\
\mathrm{U}\end{array}$ \\
\hline
\end{tabular}




\begin{tabular}{|c|c|c|c|c|c|c|c|c|c|}
\hline & & & & & & & & custody & \\
\hline $\begin{array}{l}\text { Hunt et } \\
\text { al. (2007) }\end{array}$ & E, B, S & $\begin{array}{l}\text { Question } \\
\text { naires; } \\
\text { structured } \\
\text { interview }\end{array}$ & Parents & $\begin{array}{l}129 \\
\text { parents }\end{array}$ & $\begin{array}{l}8-18 \\
\text { year } \\
\text { s }\end{array}$ & $\begin{array}{l}96 \\
\text { controls }\end{array}$ & $\begin{array}{l}3 \text { centres, } \\
\text { UK }\end{array}$ & $\begin{array}{l}\text { Syndromi } \\
\text { c cleft; } \\
\text { learning } \\
\text { disabilitie } \\
\text { s; } \\
\text { significan } \\
\text { t medical } \\
\text { history }\end{array}$ & $\begin{array}{l}\mathrm{V} \text { and } \\
\mathrm{U}\end{array}$ \\
\hline $\begin{array}{l}\text { Noor \& } \\
\text { Musa } \\
(2007)\end{array}$ & $\mathrm{E}, \mathrm{S}, \mathrm{T}$ & $\begin{array}{l}\text { Structure } \\
\mathrm{d} \\
\text { interview }\end{array}$ & $\begin{array}{l}\text { Patients } \\
\text { and } \\
\text { parents }\end{array}$ & $\begin{array}{l}60 \\
\text { patients } \\
\text { and their } \\
\text { parents }\end{array}$ & $\begin{array}{l}12- \\
17 \\
\text { year } \\
\text { s }\end{array}$ & None & $\begin{array}{l}\text { Single } \\
\text { centre, } \\
\text { Malaysia }\end{array}$ & $\begin{array}{l}\text { Syndromi } \\
\text { c cleft; } \\
\text { hearing } \\
\text { impairme } \\
\text { nt; } \\
\text { neurologi } \\
\text { cal } \\
\text { impairme } \\
\text { nt; mental } \\
\text { retardatio } \\
\text { n }\end{array}$ & $\mathrm{U}$ \\
\hline $\begin{array}{l}\text { Nopoulos } \\
\text { et al. } \\
(2007)\end{array}$ & $\mathrm{D}$ & $\begin{array}{l}\text { Cognitive } \\
\text { assessme } \\
\text { nt; } \\
\text { neuroima } \\
\text { ging; } \\
\text { medical } \\
\text { assessme } \\
\text { nt }\end{array}$ & $\begin{array}{l}\text { Professi } \\
\text { onals }\end{array}$ & 74 & $\begin{array}{l}7-17 \\
\text { year }\end{array}$ & $\begin{array}{l}74 \\
\text { controls }\end{array}$ & $\begin{array}{l}\text { Single } \\
\text { centre, } \\
\text { USA }\end{array}$ & $\begin{array}{l}\text { IQ less } \\
\text { than } 70\end{array}$ & V \\
\hline $\begin{array}{l}\text { Oosterka } \\
\text { mp et al. } \\
(2007)\end{array}$ & $\begin{array}{l}\mathrm{D}, \mathrm{E}, \mathrm{S}, \\
\mathrm{T}\end{array}$ & $\begin{array}{l}\text { naires; } \\
\text { open- } \\
\text { ended } \\
\text { questions }\end{array}$ & Patients & $\begin{array}{l}43 \text { BCLP } \\
\text { patients }\end{array}$ & $\begin{array}{l}20- \\
36 \\
\text { year } \\
\text { s }\end{array}$ & $\begin{array}{l}43 \\
\text { controls }\end{array}$ & $\begin{array}{l}\text { Single } \\
\text { centre, } \\
\text { The } \\
\text { Netherlan } \\
\text { ds }\end{array}$ & $\begin{array}{l}\text { Syndromi } \\
\text { c cleft; } \\
\text { associate } \\
\text { d } \\
\text { malforma } \\
\text { tions; } \\
\text { psychiatri } \\
\text { c } \\
\text { problems }\end{array}$ & $\begin{array}{l}\mathrm{V} \text { and } \\
\mathrm{U}\end{array}$ \\
\hline $\begin{array}{l}\text { Bashir et } \\
\text { al. (2008) }\end{array}$ & & $\begin{array}{l}\text { Retrospec } \\
\text { tive } \\
\text { clinical } \\
\text { review }\end{array}$ & $\begin{array}{l}\text { Professi } \\
\text { onals }\end{array}$ & $\begin{array}{l}191 \\
\text { patients }\end{array}$ & $\begin{array}{l}3-8 \\
\text { mont } \\
\text { hs }\end{array}$ & $\begin{array}{l}\text { Norm } \\
\text { data }\end{array}$ & $\begin{array}{l}\text { Single } \\
\text { centre, } \\
\text { UK }\end{array}$ & $\mathrm{x}$ & N/A \\
\hline $\begin{array}{l}\text { Chuo et } \\
\text { al. (2008) }\end{array}$ & $\mathrm{E}, \mathrm{T}$ & $\begin{array}{l}\text { Question } \\
\text { naires; } \\
\text { medical } \\
\text { assessme } \\
\text { nt }\end{array}$ & $\begin{array}{l}\text { Patients, } \\
\text { professi } \\
\text { onals }\end{array}$ & $\begin{array}{l}145 \\
\text { patients }\end{array}$ & $\begin{array}{l}15- \\
70 \\
\text { year } \\
\text { s }\end{array}$ & None & $\begin{array}{l}\text { Single } \\
\text { centre, } \\
\text { UK }\end{array}$ & $\begin{array}{l}\text { Presentin } \\
\mathrm{g} \text { with } \\
\text { problems } \\
\text { unrelated } \\
\text { to cleft }\end{array}$ & $\mathrm{U}$ \\
\hline $\begin{array}{l}\text { Conrad et } \\
\text { al. (2008) }\end{array}$ & $\mathrm{D}$ & $\begin{array}{l}\text { Cognitive } \\
\text { assessme } \\
\mathrm{nt}\end{array}$ & $\begin{array}{l}\text { Professi } \\
\text { onals }\end{array}$ & $\begin{array}{l}77 \\
\text { patients }\end{array}$ & $\begin{array}{l}\text { 7-17 } \\
\text { year } \\
\text { s }\end{array}$ & $\begin{array}{l}89 \\
\text { controls }\end{array}$ & $\begin{array}{l}\text { Single } \\
\text { centre, } \\
\text { USA }\end{array}$ & $\begin{array}{l}\text { Syndromi } \\
\text { c cleft }\end{array}$ & $\mathrm{V}$ \\
\hline Kramer et & $\mathrm{E}, \mathrm{G}$ & Question & Patients, & 147 & $5-6$ & None & Single & Primary & $\mathrm{V}$ \\
\hline
\end{tabular}




\begin{tabular}{|c|c|c|c|c|c|c|c|c|c|}
\hline al. (2008) & & naires & parents & $\begin{array}{l}\text { patients } \\
\text { and their } \\
\text { parents }\end{array}$ & $\begin{array}{l}\text { year } \\
\text { s }\end{array}$ & & $\begin{array}{l}\text { centre, } \\
\text { Germany }\end{array}$ & $\begin{array}{l}\text { surgical } \\
\text { treatment } \\
\text { not } \\
\text { complete } \\
\text { d; non- } \\
\text { cleft } \\
\text { medical } \\
\text { treatment } \\
3 \text { months } \\
\text { prior to } \\
\text { study }\end{array}$ & \\
\hline $\begin{array}{l}\text { Luoto et } \\
\text { al. (2008) }\end{array}$ & E, S & $\begin{array}{l}\text { Question } \\
\text { naires }\end{array}$ & Patients & $\begin{array}{l}51 \\
\text { patients }\end{array}$ & $\begin{array}{l}11- \\
14 \\
\text { year } \\
\text { s }\end{array}$ & $\begin{array}{l}82 \\
\text { controls }\end{array}$ & $\begin{array}{l}\text { Single } \\
\text { centre, } \\
\text { Finland }\end{array}$ & & $V$ \\
\hline $\begin{array}{l}\text { Murray et } \\
\text { al. (2008) }\end{array}$ & $\mathrm{D}, \mathrm{B}, \mathrm{S}$ & $\begin{array}{l}\text { Longitudi } \\
\text { nal } \\
\text { observati } \\
\text { on; } \\
\text { structured } \\
\text { interview }\end{array}$ & $\begin{array}{l}\text { Professi } \\
\text { onals, } \\
\text { parents }\end{array}$ & $\begin{array}{l}94 \\
\text { mothers }\end{array}$ & $\begin{array}{l}0-2 \\
\text { year } \\
\mathrm{s}\end{array}$ & $\begin{array}{l}96 \\
\text { contro }\end{array}$ & & $\begin{array}{l}\text { Prematur } \\
\text { e birth; } \\
\text { low birth } \\
\text { weight; } \\
\text { syndromi } \\
\text { c cleft }\end{array}$ & V \\
\hline $\begin{array}{l}\text { Persson } \\
\text { et al. } \\
(2008)\end{array}$ & $\mathrm{D}$ & $\begin{array}{l}\text { Cognitive } \\
\text { assessme } \\
\text { nt }\end{array}$ & & $\begin{array}{l}423 \text { male } \\
\text { patients }\end{array}$ & $\begin{array}{l}17- \\
19 \\
\text { year } \\
\text { s }\end{array}$ & $\begin{array}{l}\text { Registry } \\
\text { data }\end{array}$ & $\begin{array}{l}\text { Registry, } \\
\text { Sweden }\end{array}$ & $\begin{array}{l}\text { Severe } \\
\text { handicap } \\
\text { or } \\
\text { chronic } \\
\text { disease } \\
\text { which } \\
\text { prevents } \\
\text { mandator } \\
\text { y military } \\
\text { enrolmen } \\
\text { t; other } \\
\text { congenita } \\
\text { l } \\
\text { malforma } \\
\text { tion; } \\
\text { chromoso } \\
\text { mal } \\
\text { abnormal } \\
\text { ities; men } \\
\text { who have } \\
\text { emigrated }\end{array}$ & V \\
\hline $\begin{array}{l}\text { Scherer et } \\
\text { al. (2008) }\end{array}$ & $\mathrm{D}$ & $\begin{array}{l}\text { Observati } \\
\text { on; } \\
\text { longitudi } \\
\text { nal } \\
\text { cognitive } \\
\text { assessme } \\
\text { nt }\end{array}$ & $\begin{array}{l}\text { Professi } \\
\text { onals }\end{array}$ & $\begin{array}{l}13 \\
\text { patients }\end{array}$ & $\begin{array}{l}0-2 \\
\text { year } \\
\mathrm{s}\end{array}$ & $\begin{array}{l}13 \\
\text { controls }\end{array}$ & $\begin{array}{l}\text { Single } \\
\text { centre, } \\
\text { USA }\end{array}$ & $\mathrm{x}$ & $\mathrm{V}$ \\
\hline $\begin{array}{l}\text { Sharp et } \\
\text { al. (2008) }\end{array}$ & $\mathrm{T}$ & $\begin{array}{l}\text { Semi- } \\
\text { structured } \\
\text { interview }\end{array}$ & Parents & $\begin{array}{l}75 \\
\text { parents }\end{array}$ & $\begin{array}{l}2-22 \\
\text { year } \\
\mathrm{s}\end{array}$ & None & $\begin{array}{l}\text { Single } \\
\text { region, } \\
\text { The }\end{array}$ & $\begin{array}{l}\text { Surgery } \\
\text { less than } \\
\text { six }\end{array}$ & $\begin{array}{l}\text { U, } \\
\text { Conten } \\
\mathrm{t}\end{array}$ \\
\hline
\end{tabular}




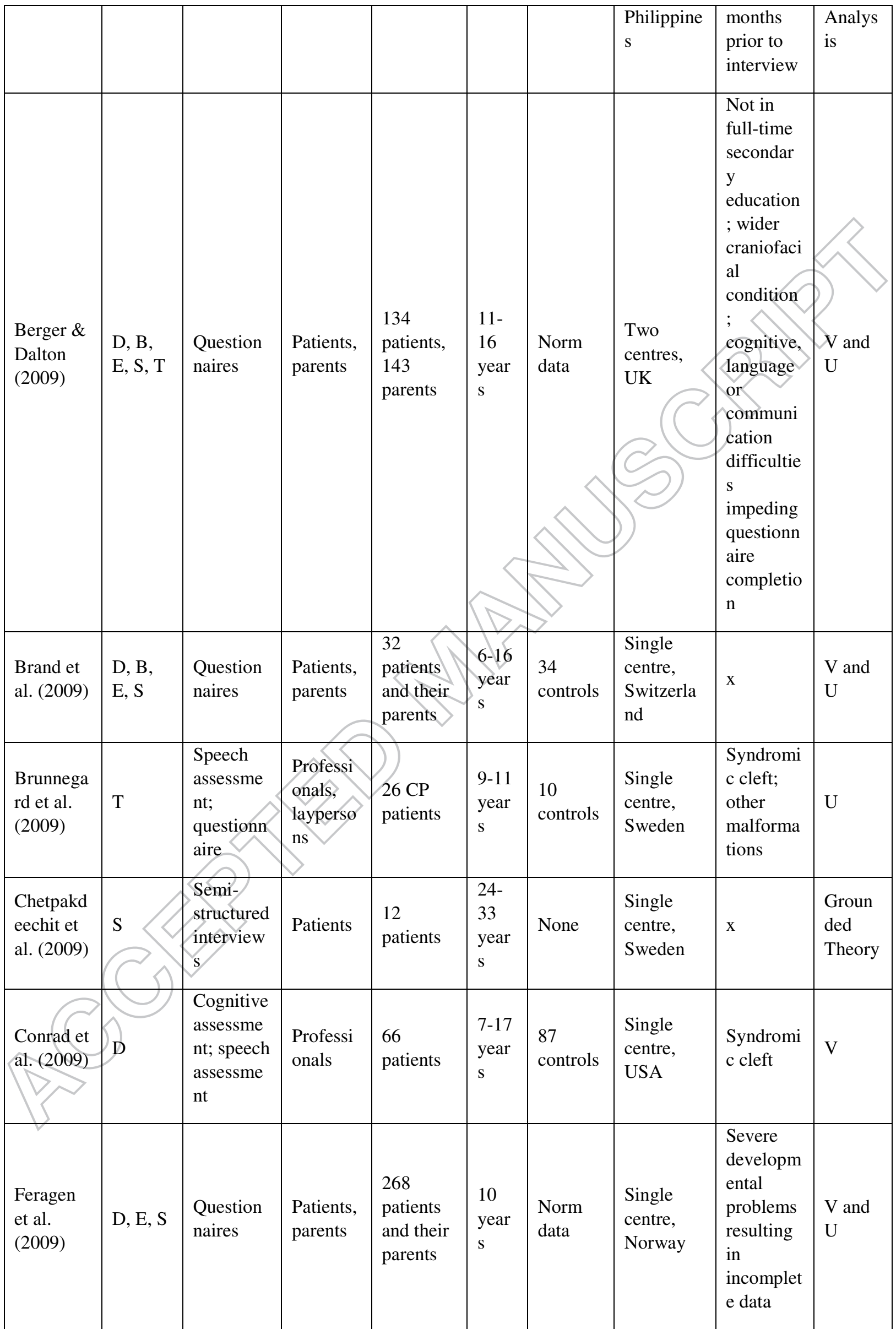




\begin{tabular}{|c|c|c|c|c|c|c|c|c|c|}
\hline $\begin{array}{l}\text { Kramer et } \\
\text { al. (2009) }\end{array}$ & $\mathrm{S}$ & $\begin{array}{l}\text { Question } \\
\text { naires }\end{array}$ & $\begin{array}{l}\text { Patients, } \\
\text { parents }\end{array}$ & $\begin{array}{l}132 \\
\text { patients } \\
\text { and their } \\
\text { parents }\end{array}$ & $\begin{array}{l}8-12 \\
\text { year } \\
\text { s }\end{array}$ & $\begin{array}{l}\text { Norm } \\
\text { data }\end{array}$ & $\begin{array}{l}\text { Single } \\
\text { centre, } \\
\text { Germany }\end{array}$ & $\begin{array}{l}\text { Diagnose } \\
\mathrm{d} \\
\text { syndrome } \\
\text {; medical } \\
\text { care } \\
\text { unrelated } \\
\text { to cleft } \\
\text { treatment } \\
3 \text { months } \\
\text { prior to } \\
\text { study }\end{array}$ & V \\
\hline $\begin{array}{l}\text { Meyer- } \\
\text { Marcotty } \\
\& \\
\text { Stellzig- } \\
\text { Eisenhau } \\
\text { er (2009) }\end{array}$ & $\mathrm{T}$ & $\begin{array}{l}\text { Question } \\
\text { naire; 3D } \\
\text { facial } \\
\text { imaging; } \\
\text { assessme } \\
\text { nts of } \\
\text { photograp } \\
\text { hs }\end{array}$ & $\begin{array}{l}\text { Professi } \\
\text { onals, } \\
\text { layperso } \\
\text { ns }\end{array}$ & $\begin{array}{l}30 \\
\text { patient } \\
\text { photogra } \\
\text { phs, } 10 \\
\text { orthodont } \\
\text { ists, } 10 \\
\text { surgeons, } \\
15 \\
\text { layperson } \\
\text { s }\end{array}$ & $\begin{array}{l}18- \\
32 \\
\text { year } \\
\text { s }\end{array}$ & None & $\begin{array}{l}\text { Single } \\
\text { centre, } \\
\text { Germany }\end{array}$ & $\begin{array}{l}\text { Syndromi } \\
\text { c cleft; } \\
\text { other } \\
\text { congentia } \\
\text { l facial } \\
\text { anomalie } \\
\text { s; any } \\
\text { outstandi } \\
\text { ng facial } \\
\text { characteri } \\
\text { stics (e.g. } \\
\text { tattoo, } \\
\text { piercing); } \\
\text { psychiatri } \\
\text { c } \\
\text { disorders }\end{array}$ & $\mathrm{U}$ \\
\hline $\begin{array}{l}\text { Ruiter et } \\
\text { al. (2009) }\end{array}$ & $\mathrm{D}, \mathrm{S}$ & $\begin{array}{l}\text { Retrospec } \\
\text { tive } \\
\text { longitudi } \\
\text { nal } \\
\text { clinical } \\
\text { review }\end{array}$ & & $\begin{array}{l}63 \\
\text { patients }\end{array}$ & $\begin{array}{l}2-3 \\
\text { year } \\
\mathrm{s} \\
\text { and } \\
\text { agai } \\
\mathrm{n} \text { at } \\
5-6 \\
\text { year } \\
\mathrm{s}\end{array}$ & $\begin{array}{l}\text { Norm } \\
\text { data }\end{array}$ & $\begin{array}{l}\text { Single } \\
\text { centre, } \\
\text { The } \\
\text { Netherlan } \\
\text { ds }\end{array}$ & $\begin{array}{l}\text { Missing } \\
\text { data; ot } \\
\text { speaking } \\
\text { Dutch; } \\
\text { syndromi } \\
\text { c cleft; } \\
\text { other } \\
\text { developm } \\
\text { ental } \\
\text { problem }\end{array}$ & $\begin{array}{l}\mathrm{V} \text { and } \\
\mathrm{U}\end{array}$ \\
\hline $\begin{array}{l}\text { Sagheri et } \\
\text { al. (2009) }\end{array}$ & & $\begin{array}{l}\text { Structure } \\
\text { d } \\
\text { interview }\end{array}$ & Parents & $\begin{array}{l}61 \\
\text { parents }\end{array}$ & $\begin{array}{l}\text { 4-7 } \\
\text { year } \\
\text { s }\end{array}$ & $\begin{array}{l}\text { Nationa } \\
\text { l survey } \\
\text { data }\end{array}$ & $\begin{array}{l}\text { Single } \\
\text { centre, } \\
\text { Germany }\end{array}$ & $\begin{array}{l}\text { Syndromi } \\
\text { c cleft }\end{array}$ & $\mathrm{V}$ \\
\hline $\begin{array}{l}\text { Collett, } \\
\text { Leroux et } \\
\text { al. (2010) }\end{array}$ & $\mathrm{D}$ & $\begin{array}{l}\text { Observati } \\
\text { on; } \\
\text { longitudi } \\
\text { nal } \\
\text { cognitive } \\
\text { assessme } \\
\text { nt; } \\
\text { structured } \\
\text { interview }\end{array}$ & $\begin{array}{l}\text { Professi } \\
\text { onals, } \\
\text { parents }\end{array}$ & $\begin{array}{l}57 \\
\text { patients }\end{array}$ & $\begin{array}{l}3 \\
\text { mont } \\
\text { hs, } \\
12 \\
\text { mont } \\
\text { hs, } 2 \\
\text { year } \\
\text { s, } 5 \\
\text { year } \\
\text { s, } 7 \\
\text { year } \\
\text { s }\end{array}$ & $\begin{array}{l}77 \\
\text { controls }\end{array}$ & $\begin{array}{l}\text { Single } \\
\text { centre, } \\
\text { USA }\end{array}$ & $\begin{array}{l}\text { Syndromi } \\
\text { c cleft; } \\
\text { additional } \\
\text { birth } \\
\text { defects; } \\
\text { perinatal } \\
\text { problems }\end{array}$ & $\mathrm{V}$ \\
\hline
\end{tabular}




\begin{tabular}{|c|c|c|c|c|c|c|c|c|c|}
\hline $\begin{array}{l}\text { Collett, } \\
\text { Stott- } \\
\text { Miller et } \\
\text { al. (2010) }\end{array}$ & D & $\begin{array}{l}\text { Cognitive } \\
\text { assessme } \\
\text { nt; } \\
\text { structured } \\
\text { interview }\end{array}$ & $\begin{array}{l}\text { Professi } \\
\text { onals, } \\
\text { parents }\end{array}$ & $\begin{array}{l}42 \\
\text { patients }\end{array}$ & $\begin{array}{l}5-7 \\
\text { year } \\
\text { s }\end{array}$ & $\begin{array}{l}43 \\
\text { controls }\end{array}$ & $\begin{array}{l}\text { Single } \\
\text { centre, } \\
\text { USA }\end{array}$ & $\begin{array}{l}\text { Syndromi } \\
\text { c cleft; } \\
\text { English } \\
\text { not } \\
\text { primary } \\
\text { language; } \\
\text { visual or } \\
\text { auditory } \\
\text { impairme } \\
\text { nts; } \\
\text { history of } \\
\text { mental } \\
\text { retardatio }\end{array}$ & \\
\hline $\begin{array}{l}\text { Feragen } \\
\& \text { Borge } \\
(2010)\end{array}$ & S & $\begin{array}{l}\text { Question } \\
\text { naires }\end{array}$ & $\begin{array}{l}\text { Patients, } \\
\text { parents }\end{array}$ & $\begin{array}{l}661 \\
\text { patients } \\
\text { and their } \\
\text { parents }\end{array}$ & $\begin{array}{l}10 \\
\text { year } \\
s, 16 \\
\text { year } \\
\text { s }\end{array}$ & $\begin{array}{l}\text { Norm } \\
\text { data }\end{array}$ & $\begin{array}{l}\text { Single } \\
\text { centre, } \\
\text { Norway }\end{array}$ & $\begin{array}{l}\text { Severe } \\
\text { developm } \\
\text { ental } \\
\text { problems } \\
\text { resulting } \\
\text { in } \\
\text { incomplet } \\
\text { e data }\end{array}$ & $\begin{array}{l}\mathrm{V} \text { and } \\
\mathrm{U}\end{array}$ \\
\hline $\begin{array}{l}\text { Feragen, } \\
\text { Kvalem } \\
\text { et al. } \\
(2010)\end{array}$ & E, S & & Patients & $\begin{array}{l}289 \\
\text { patients }\end{array}$ & $\begin{array}{l}16 \\
\text { year } \\
\mathrm{s}\end{array}$ & $\begin{array}{l}\text { Norm } \\
\text { data }\end{array}$ & $\begin{array}{l}\text { Single } \\
\text { centre, } \\
\text { Norway }\end{array}$ & $\begin{array}{l}\text { Severe } \\
\text { developm } \\
\text { ental } \\
\text { problems } \\
\text { resulting } \\
\text { in } \\
\text { incomplet } \\
\text { e data }\end{array}$ & $\mathrm{V}$ \\
\hline $\begin{array}{l}\text { Mani et } \\
\text { al. (2010) }\end{array}$ & E, S, T & $\begin{array}{l}\text { Question } \\
\text { naires }\end{array}$ & Patients & $\begin{array}{l}86 \text { UCLP } \\
\text { patients }\end{array}$ & $\begin{array}{l}20- \\
47 \\
\text { year } \\
\text { s }\end{array}$ & $\begin{array}{l}\text { Norm } \\
\text { data }\end{array}$ & $\begin{array}{l}\text { Single } \\
\text { centre, } \\
\text { Sweden }\end{array}$ & $\begin{array}{l}\text { Syndromi } \\
\text { c cleft }\end{array}$ & $\mathrm{V}$ \\
\hline $\begin{array}{l}\text { Meyer- } \\
\text { Marcotty, } \\
\text { Alpers et } \\
\text { al. (2010) }\end{array}$ & $\mathrm{S}, \mathrm{T}$ & $\begin{array}{l}\text { 3D facial } \\
\text { imaging; } \\
\text { eye- } \\
\text { tracking }\end{array}$ & $\begin{array}{l}\text { Laypers } \\
\text { ons }\end{array}$ & $\begin{array}{l}18 \text { UCLP } \\
\text { patient } \\
\text { photogra } \\
\text { phs, } 18 \\
\text { control } \\
\text { photogra } \\
\text { phs, } 30 \\
\text { layperson } \\
\text { s }\end{array}$ & $\begin{array}{l}17- \\
39 \\
\text { year } \\
\text { s }\end{array}$ & $\begin{array}{l}20 \\
\text { orthogn } \\
\text { athic } \\
\text { patients } \\
\text { with } \\
\text { Class } \\
\text { III, 20 } \\
\text { controls } \\
\text { with } \\
\text { Class I }\end{array}$ & $\begin{array}{l}\text { Single } \\
\text { centre, } \\
\text { Germany }\end{array}$ & $\begin{array}{l}\text { No } \\
\text { associate } \\
\mathrm{d} \\
\text { malforma } \\
\text { tions or } \\
\text { other } \\
\text { distinctiv } \\
\text { e facial } \\
\text { features; } \\
\text { incomplet } \\
\text { e cleft }\end{array}$ & $\mathrm{U}$ \\
\hline
\end{tabular}




\begin{tabular}{|c|c|c|c|c|c|c|c|c|c|}
\hline $\begin{array}{l}\text { Meyer- } \\
\text { Marcotty, } \\
\text { Reuther } \\
\text { et al. } \\
(2010)\end{array}$ & $\mathrm{T}$ & $\begin{array}{l}\text { 3D facial } \\
\text { imaging; } \\
\text { assessme } \\
\text { nt of } \\
\text { photograp } \\
\text { hs }\end{array}$ & $\begin{array}{l}\text { Laypers } \\
\text { ons }\end{array}$ & $\begin{array}{l}18 \\
\text { patient } \\
\text { photogra } \\
\text { phs, } 18 \\
\text { control } \\
\text { photogra } \\
\text { phs, } 30 \\
\text { layperson } \\
\text { s }\end{array}$ & $\begin{array}{l}17- \\
39 \\
\text { year } \\
\text { s }\end{array}$ & $\begin{array}{l}20 \\
\text { orthogn } \\
\text { athic } \\
\text { patients } \\
\text { with } \\
\text { Class } \\
\text { III, 20 } \\
\text { controls } \\
\text { with } \\
\text { Class I }\end{array}$ & $\begin{array}{l}\text { Single } \\
\text { centre, } \\
\text { Germany }\end{array}$ & $\begin{array}{l}\text { No } \\
\text { associate } \\
\mathrm{d} \\
\text { malforma } \\
\text { tions or } \\
\text { other } \\
\text { distinctiv } \\
\text { e facial } \\
\text { features; } \\
\text { complete } \\
\text { UCLP }\end{array}$ & $\mathrm{U}$ \\
\hline $\begin{array}{l}\text { Murray et } \\
\text { al. (2010) }\end{array}$ & $\mathrm{E}, \mathrm{B}, \mathrm{S}$ & $\begin{array}{l}\text { Observati } \\
\text { on; } \\
\text { medical } \\
\text { assessme } \\
\text { nt }\end{array}$ & $\begin{array}{l}\text { Parents, } \\
\text { patients, } \\
\text { teachers, } \\
\text { professi } \\
\text { onals }\end{array}$ & $\begin{array}{l}93 \\
\text { patients }\end{array}$ & $\begin{array}{l}7 \\
\text { year } \\
\text { s }\end{array}$ & $\begin{array}{l}77 \\
\text { controls }\end{array}$ & $\begin{array}{l}2 \text { centres, } \\
\text { UK }\end{array}$ & $\begin{array}{l}\text { Other } \\
\text { abnormal } \\
\text { ities or } \\
\text { health } \\
\text { problems }\end{array}$ & $\mathrm{V}$ \\
\hline $\begin{array}{l}\text { Nopoulos } \\
\text { et al. } \\
(2010)\end{array}$ & $\mathrm{D}, \mathrm{B}$ & $\begin{array}{l}\text { Question } \\
\text { naires, } \\
\text { neuroima } \\
\text { ging }\end{array}$ & $\begin{array}{l}\text { Parents, } \\
\text { teachers, } \\
\text { professi } \\
\text { onals }\end{array}$ & $\begin{array}{l}50 \text { male } \\
\text { patients }\end{array}$ & & & $\begin{array}{l}\text { Single } \\
\text { centre, } \\
\text { USA }\end{array}$ & $\begin{array}{l}\text { Syndromi } \\
\text { c cleft; } \\
\text { IQ less } \\
\text { than 70; } \\
\text { major } \\
\text { medical, } \\
\text { neurologi } \\
\text { c or } \\
\text { psychiatri } \\
\text { c illness; } \\
\text { learning } \\
\text { disability }\end{array}$ & $\mathrm{V}$ \\
\hline $\begin{array}{l}\text { Snyder \& } \\
\text { Pope } \\
(2010)\end{array}$ & $\mathrm{D}, \mathrm{B}, \mathrm{S}$ & $\begin{array}{l}\text { Question } \\
\text { naires }\end{array}$ & & $\begin{array}{l}144 \\
\text { parents }\end{array}$ & $\begin{array}{l}2-18 \\
\text { year } \\
\text { s }\end{array}$ & $\begin{array}{l}\text { Norm } \\
\text { data }\end{array}$ & $\begin{array}{l}\text { Single } \\
\text { centre, } \\
\text { USA }\end{array}$ & $\mathrm{X}$ & V \\
\hline $\begin{array}{l}\text { Van der } \\
\text { Plas et al. } \\
(2010)\end{array}$ & $\mathrm{D}$ & $\mathrm{ma}$ & $\begin{array}{l}\text { Professi } \\
\text { onals }\end{array}$ & $\begin{array}{l}33 \text { male } \\
\text { patients }\end{array}$ & $\begin{array}{l}7-17 \\
\text { year } \\
\text { s }\end{array}$ & $\begin{array}{l}57 \\
\text { controls }\end{array}$ & $\begin{array}{l}\text { Single } \\
\text { centre, } \\
\text { USA }\end{array}$ & $\begin{array}{l}\text { Syndromi } \\
\text { c cleft; } \\
\text { history of } \\
\text { medical } \\
\text { or } \\
\text { neurologi } \\
\text { c disease }\end{array}$ & N/A \\
\hline $\begin{array}{l}\text { Versnel } \\
\text { et al. } \\
(2010)\end{array}$ & $\mathrm{E}, \mathrm{S}, \mathrm{T}$ & $\begin{array}{l}\text { Question } \\
\text { naires }\end{array}$ & Patients & $\begin{array}{l}59 \\
\text { patients }\end{array}$ & $\begin{array}{l}34- \\
45 \\
\text { year } \\
\text { s }\end{array}$ & $\begin{array}{l}59 \\
\text { patients } \\
\text { with } \\
\text { facial } \\
\text { trauma; } \\
201 \\
\text { controls }\end{array}$ & $\begin{array}{l}\text { Single } \\
\text { centre, } \\
\text { The } \\
\text { Netherlan } \\
\text { ds }\end{array}$ & $\begin{array}{l}\text { Incomple } \\
\text { te data; } \\
\text { under } 18 \\
\text { years of } \\
\text { age; } \\
\text { mentally } \\
\text { retarded; } \\
\text { blind; } \\
\text { non- } \\
\text { Dutch } \\
\text { speaking; } \\
\text { additional } \\
\text { congentia } \\
\text { l }\end{array}$ & $\begin{array}{l}\mathrm{V} \text { and } \\
\mathrm{U}\end{array}$ \\
\hline
\end{tabular}




\begin{tabular}{|c|c|c|c|c|c|c|c|c|c|}
\hline & & & & & & & & $\begin{array}{l}\text { craniofaci } \\
\text { al } \\
\text { condition }\end{array}$ & \\
\hline $\begin{array}{l}\text { Young et } \\
\text { al. (2010) }\end{array}$ & $\mathrm{D}$ & $\begin{array}{l}\text { Cognitive } \\
\text { assessme } \\
\mathrm{nt}\end{array}$ & $\begin{array}{l}\text { Professi } \\
\text { onals }\end{array}$ & $\begin{array}{l}43 \\
\text { patients }\end{array}$ & $\begin{array}{l}3-6 \\
\text { year } \\
s\end{array}$ & $\begin{array}{l}\text { Norm } \\
\text { data }\end{array}$ & $\begin{array}{l}\text { Single } \\
\text { centre, } \\
\text { China }\end{array}$ & $\begin{array}{l}\text { Syndromi } \\
\text { c cleft; } \\
\text { neurologi } \\
\text { cal or } \\
\text { additional } \\
\text { congenita } \\
1 \\
\text { abnormal } \\
\text { ities; } \\
\text { sensorine } \\
\text { ural } \\
\text { hearing } \\
\text { problems; } \\
\text { intellectu } \\
\text { al } \\
\text { impairme } \\
\text { nt; } \\
\text { developm } \\
\text { ental } \\
\text { delay }\end{array}$ & 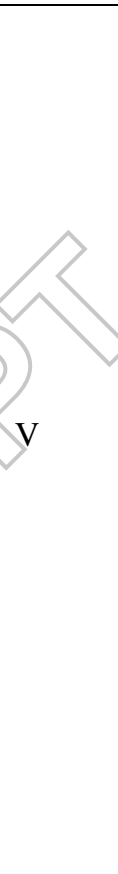 \\
\hline $\begin{array}{l}\text { Yttri et } \\
\text { al. (2010) }\end{array}$ & $\mathrm{S}$ & $\begin{array}{l}\text { Retrospec } \\
\text { tive } \\
\text { clinical } \\
\text { review }\end{array}$ & $\begin{array}{l}\text { Professi } \\
\text { onals }\end{array}$ & $\begin{array}{l}1931 \\
\text { female } \\
\text { patients }\end{array}$ & $\begin{array}{l}15+ \\
\text { year } \\
\text { s }\end{array}$ & $\begin{array}{l}\text { Registry } \\
\text { data }\end{array}$ & $\begin{array}{l}\text { Registry, } \\
\text { Denmark }\end{array}$ & $\begin{array}{l}\text { Emigratio } \\
\text { n; having } \\
\text { children } \\
\text { before } \\
\text { age } 15 \\
\text { years; } \\
\text { syndromi } \\
\text { c cleft; } \\
\text { major } \\
\text { anomalie } \\
\text { s }\end{array}$ & N/A \\
\hline $\begin{array}{l}\text { Augsorn } \\
\text { wan et al. } \\
\text { (2011) }\end{array}$ & E, T & $\begin{array}{l}\text { Question } \\
\text { naires; } \\
\text { semi- } \\
\text { structured } \\
\text { interview }\end{array}$ & Patients & $\begin{array}{l}33 \\
\text { patients } \\
\text { complete } \\
\text { d } \\
\text { questionn } \\
\text { aires, } 15 \\
\text { patients } \\
\text { were } \\
\text { interview } \\
\text { ed }\end{array}$ & $\begin{array}{l}8-18 \\
\text { year } \\
\mathrm{s}\end{array}$ & $\begin{array}{l}\text { Norm } \\
\text { data }\end{array}$ & $\begin{array}{l}\text { Single } \\
\text { centre, } \\
\text { Thailand }\end{array}$ & $\begin{array}{l}\text { Other } \\
\text { anomalie } \\
\text { s }\end{array}$ & $\begin{array}{l}\mathrm{V} \text {, } \\
\text { Conten } \\
\mathrm{t} \\
\text { Analys } \\
\text { is }\end{array}$ \\
\hline $\begin{array}{l} \\
\text { Berger \& } \\
\text { Dalton } \\
(2011)\end{array}$ & $\mathrm{E}, \mathrm{S}, \mathrm{T}$ & $\begin{array}{l}\text { Question } \\
\text { naires }\end{array}$ & $\begin{array}{l}\text { Patients, } \\
\text { parents }\end{array}$ & $\begin{array}{l}91 \\
\text { patients } \\
\text { and their } \\
\text { mothers }\end{array}$ & $\begin{array}{l}11- \\
16 \\
\text { year } \\
\text { s }\end{array}$ & $\begin{array}{l}\text { Norm } \\
\text { data }\end{array}$ & $\begin{array}{l}2 \text { centres, } \\
\text { UK }\end{array}$ & $\begin{array}{l}\text { Other } \\
\text { craniofaci } \\
\text { al } \\
\text { condition } \\
; \\
\text { cognitive, } \\
\text { language } \\
\text { or } \\
\text { communi }\end{array}$ & $\begin{array}{l}\mathrm{V} \text { and } \\
\mathrm{U}\end{array}$ \\
\hline
\end{tabular}




\begin{tabular}{|c|c|c|c|c|c|c|c|c|c|}
\hline & & & & & & & & $\begin{array}{l}\text { cation } \\
\text { difficultie } \\
\mathrm{s}\end{array}$ & \\
\hline $\begin{array}{l}\text { Bos \& } \\
\text { Prahl } \\
\text { (2011) }\end{array}$ & $\mathrm{D}, \mathrm{E}, \mathrm{T}$ & $\begin{array}{l}\text { Question } \\
\text { naire }\end{array}$ & $\begin{array}{l}\text { Patients, } \\
\text { parents }\end{array}$ & $\begin{array}{l}122 \\
\text { patients } \\
\text { and their } \\
\text { parents }\end{array}$ & $\begin{array}{l}8-15 \\
\text { year } \\
\mathrm{s}\end{array}$ & $\begin{array}{l}\text { Norm } \\
\text { data }\end{array}$ & $\begin{array}{l}\text { Single } \\
\text { centre, } \\
\text { The } \\
\text { Netherlan } \\
\text { ds }\end{array}$ & $\mathrm{x}$ & $\mathrm{V}$ \\
\hline $\begin{array}{l}\text { Chetpakd } \\
\text { eechit et } \\
\text { al. (2011) }\end{array}$ & $\mathrm{T}$ & $\begin{array}{l}\text { Assessme } \\
\text { nt of } \\
\text { photograp } \\
\text { hs }\end{array}$ & $\begin{array}{l}\text { Professi } \\
\text { onals, } \\
\text { layperso } \\
\text { ns }\end{array}$ & $\begin{array}{l}12 \text { BCLP } \\
\text { patient } \\
\text { photogra } \\
\text { phs, } 25 \\
\text { orthodont } \\
\text { ists, } 20 \\
\text { layperson } \\
\text { s }\end{array}$ & $\begin{array}{l}16- \\
19 \\
\text { year } \\
\text { s }\end{array}$ & None & $\begin{array}{l}\text { Single } \\
\text { centre, } \\
\text { Sweden }\end{array}$ & $\begin{array}{l}\text { Not } \\
\text { complete } \\
\text { d } \\
\text { treatment } \\
\text {; mental } \\
\text { disorders; } \\
\text { other } \\
\text { craniofaci } \\
\text { al defects }\end{array}$ & $\mathrm{U}$ \\
\hline $\begin{array}{l}\text { Chimruan } \\
\text { g et al. } \\
\text { (2011) }\end{array}$ & $\mathrm{E}, \mathrm{S}, \mathrm{T}$ & $\begin{array}{l}\text { Semi- } \\
\text { structured } \\
\text { interview } \\
\mathrm{s}, \\
\text { participat } \\
\text { ory } \\
\text { activities }\end{array}$ & $\begin{array}{l}\text { Patients, } \\
\text { parents }\end{array}$ & $\begin{array}{l}18 \\
\text { patients, } \\
6 \text { parents }\end{array}$ & $\begin{array}{l}12- \\
17 \\
\text { year } \\
\text { s }\end{array}$ & & $\begin{array}{l}\text { Single } \\
\text { centre, } \\
\text { Thailand }\end{array}$ & $\begin{array}{l}\text { Syndromi } \\
\text { c cleft; } \\
\text { additional } \\
\text { disabilitie } \\
\text { s }\end{array}$ & $\begin{array}{l}\text { Conten } \\
\mathrm{t} \\
\text { analysi } \\
\mathrm{s}\end{array}$ \\
\hline $\begin{array}{l}\text { Demir et } \\
\text { al. (2011) }\end{array}$ & $\begin{array}{l}\mathrm{D}, \mathrm{E}, \mathrm{S}, \\
\mathrm{T}\end{array}$ & $\begin{array}{l}\text { Question } \\
\text { naires; } \\
\text { cognitive } \\
\text { assessme } \\
\text { nt }\end{array}$ & $\begin{array}{l}\text { Patients, } \\
\text { professi } \\
\text { onals }\end{array}$ & $\begin{array}{l}20 \\
\text { patients }\end{array}$ & $\begin{array}{l}6-16 \\
\text { year } \\
\text { s }\end{array}$ & $\begin{array}{l}40 \\
\text { controls }\end{array}$ & $\begin{array}{l}\text { Single } \\
\text { centre, } \\
\text { Turkey }\end{array}$ & $\begin{array}{l}\text { Syndromi } \\
\text { c cleft; } \\
\text { other } \\
\text { deformity } \\
\text { with } \\
\text { cosmetic } \\
\text { disfigure } \\
\text { ment; } \\
\text { chronic } \\
\text { disease; } \\
\text { hearing } \\
\text { impairme } \\
\text { nt }\end{array}$ & $\begin{array}{l}\mathrm{V} \text { and } \\
\mathrm{U}\end{array}$ \\
\hline $\begin{array}{l}\text { Despars } \\
\text { et al. } \\
(2011)\end{array}$ & $\mathrm{S}$ & $\begin{array}{l}\text { Semi- } \\
\text { structured } \\
\text { interview; } \\
\text { longitudi } \\
\text { nal } \\
\text { questionn } \\
\text { aires }\end{array}$ & Parents & $\begin{array}{l}22 \\
\text { mothers }\end{array}$ & $\begin{array}{l}2-3 \\
\text { mont } \\
\text { hs, } 1 \\
\text { year }\end{array}$ & $\begin{array}{l}\text { Norm } \\
\text { data }\end{array}$ & $\begin{array}{l}\text { Single } \\
\text { centre, } \\
\text { Switzerla } \\
\text { nd }\end{array}$ & $\begin{array}{l}\text { Syndromi } \\
\text { c cleft; } \\
\text { cleft } \\
\text { palate } \\
\text { only; } \\
\text { parental } \\
\text { psychiatri } \\
\text { c illness } \\
\text { or drug } \\
\text { abuse; } \\
\text { difficulty } \\
\text { speaking } \\
\text { French }\end{array}$ & $\begin{array}{l}\mathrm{V}, \\
\text { Conten } \\
\mathrm{t} \\
\text { analysi } \\
\mathrm{s}\end{array}$ \\
\hline $\begin{array}{l}\text { Havstam, } \\
\text { Laakso, }\end{array}$ & E, $S$ & $\begin{array}{l}\text { Semi- } \\
\text { structured }\end{array}$ & Patients & 13 & $\begin{array}{l}25- \\
34\end{array}$ & None & $\begin{array}{l}\text { Single } \\
\text { centre, }\end{array}$ & $\begin{array}{l}\text { No } \\
\text { palatal }\end{array}$ & $\begin{array}{l}\text { Groun } \\
\text { ded }\end{array}$ \\
\hline
\end{tabular}




\begin{tabular}{|c|c|c|c|c|c|c|c|c|c|}
\hline $\begin{array}{l}\text { Lohmand } \\
\text { er et al. } \\
\text { (2011) }\end{array}$ & & interview & & patients & $\begin{array}{l}\text { year } \\
\mathrm{s}\end{array}$ & & Sweden & $\begin{array}{l}\text { involvem } \\
\text { ent }\end{array}$ & Theory \\
\hline $\begin{array}{l}\text { Havstam, } \\
\text { Laakso \& } \\
\text { Ringsber } \\
\text { g (2011) }\end{array}$ & S & $\begin{array}{l}\text { Longitudi } \\
\text { nal } \\
\text { speech } \\
\text { assessme } \\
\text { nt; } \\
\text { questionn } \\
\text { aires }\end{array}$ & $\begin{array}{l}\text { Patients, } \\
\text { parents, } \\
\text { professi } \\
\text { onals }\end{array}$ & $\begin{array}{l}54 \\
\text { patients } \\
\text { and their } \\
\text { parents }\end{array}$ & $\begin{array}{l}10 \\
\text { year } \\
\mathrm{s}\end{array}$ & $\begin{array}{l}\text { Norm } \\
\text { data }\end{array}$ & $\begin{array}{l}\text { Single } \\
\text { centre, } \\
\text { Sweden }\end{array}$ & $\begin{array}{l}\text { No } \\
\text { palatal } \\
\text { involvem } \\
\text { ent; } \\
\text { moved } \\
\text { away } \\
\text { from the } \\
\text { region; } \\
\text { severe } \\
\text { developm }\end{array}$ & $\mathrm{V}$ \\
\hline $\begin{array}{l}\text { Havstam, } \\
\text { Sandberg } \\
\text { et al. } \\
(2011)\end{array}$ & E, S, T & $\begin{array}{l}\text { Semi- } \\
\text { structured } \\
\text { interview }\end{array}$ & Patients & $\begin{array}{l}13 \\
\text { patients }\end{array}$ & $\begin{array}{l}25- \\
34 \\
\text { year } \\
\mathrm{s}\end{array}$ & & $\begin{array}{l}\text { Single } \\
\text { centre, } \\
\text { Sweden }\end{array}$ & $\begin{array}{l}\text { No } \\
\text { palatal } \\
\text { involvem } \\
\text { ent }\end{array}$ & $\begin{array}{l}\text { Groun } \\
\text { ded } \\
\text { Theory }\end{array}$ \\
\hline $\begin{array}{l}\text { Hens et } \\
\text { al. }(2011)\end{array}$ & $\mathrm{T}$ & $\begin{array}{l}\text { Question } \\
\text { naire; } \\
\text { assessme } \\
\text { nt of } \\
\text { photograp } \\
\text { hs }\end{array}$ & $\begin{array}{l}\text { Patients; } \\
\text { professi } \\
\text { onals }\end{array}$ & & $\begin{array}{l}60 \\
\text { year } \\
s\end{array}$ & None & $\begin{array}{l}\text { Single } \\
\text { centre, } \\
\text { Belgium }\end{array}$ & $\mathrm{x}$ & $\mathrm{U}$ \\
\hline $\begin{array}{l}\text { Hentges } \\
\text { et al. } \\
(2011)\end{array}$ & $\mathrm{D}, \mathrm{S}$ & $\begin{array}{l}\text { Observati } \\
\text { on; } \\
\text { longitudi } \\
\text { nal } \\
\text { cognitive } \\
\text { assessme }\end{array}$ & $\begin{array}{l}\text { Professi } \\
\text { onals }\end{array}$ & $\begin{array}{l}93 \\
\text { patients }\end{array}$ & $\begin{array}{l}7 \\
\text { year } \\
\text { s }\end{array}$ & $\begin{array}{l}77 \\
\text { controls }\end{array}$ & $\begin{array}{l}4 \text { centres, } \\
\text { UK }\end{array}$ & $\begin{array}{l}\text { No other } \\
\text { abnormal } \\
\text { ities; no } \\
\text { other } \\
\text { health } \\
\text { problems }\end{array}$ & $\mathrm{V}$ \\
\hline $\begin{array}{l}\text { Meyer- } \\
\text { Marcotty, } \\
\text { Gerdes et } \\
\text { al. (2011) }\end{array}$ & $T$ & $\begin{array}{l}\text { Assessme } \\
\text { nt of } \\
\text { photograp } \\
\text { hs }\end{array}$ & $\begin{array}{l}\text { Laypers } \\
\text { ons }\end{array}$ & $\begin{array}{l}30 \\
\text { patient } \\
\text { photogra } \\
\text { phs, } 20 \\
\text { orthognat } \\
\text { hic } \\
\text { patients, } \\
20 \\
\text { layperson } \\
\text { s }\end{array}$ & $\begin{array}{l}17- \\
39 \\
\text { year } \\
\text { s }\end{array}$ & $\begin{array}{l}20 \\
\text { orthogn } \\
\text { athic } \\
\text { patients, } \\
20 \\
\text { controls }\end{array}$ & $\begin{array}{l}\text { Single } \\
\text { centre, } \\
\text { Germany }\end{array}$ & $\begin{array}{l}\text { No } \\
\text { malforma } \\
\text { tions or } \\
\text { other } \\
\text { distinctiv } \\
\text { e features }\end{array}$ & $\mathrm{U}$ \\
\hline $\begin{array}{l}\text { Meyer- } \\
\text { Marcotty, } \\
\text { Kochel et } \\
\text { al. (2011) }\end{array}$ & $\mathrm{S}$ & $\begin{array}{l}\text { Assessme } \\
\text { nt of } \\
\text { photograp } \\
\text { hs; eye- } \\
\text { tracking }\end{array}$ & $\begin{array}{l}\text { Laypers } \\
\text { ons, } \\
\text { patients }\end{array}$ & $\begin{array}{l}33 \\
\text { patients, } \\
30 \\
\text { layperson } \\
\mathrm{s}\end{array}$ & $\begin{array}{l}23- \\
30 \\
\text { year } \\
\text { s }\end{array}$ & $\begin{array}{l}30 \\
\text { controls }\end{array}$ & $\begin{array}{l}\text { Single } \\
\text { centre, } \\
\text { Germany }\end{array}$ & $\begin{array}{l}\text { No other } \\
\text { congenita } \\
1 \text { facial } \\
\text { anomalie } \\
\text { s; no } \\
\text { other }\end{array}$ & $\mathrm{U}$ \\
\hline
\end{tabular}




\begin{tabular}{|c|c|c|c|c|c|c|c|c|c|}
\hline & & & & & & & & $\begin{array}{l}\text { distinctiv } \\
\text { e facial } \\
\text { features }\end{array}$ & \\
\hline $\begin{array}{l}\text { Munz et } \\
\text { al. (2011) }\end{array}$ & $\mathrm{E}, \mathrm{S}, \mathrm{T}$ & $\begin{array}{l}\text { Question } \\
\text { naires }\end{array}$ & $\begin{array}{l}\text { Patients, } \\
\text { parents }\end{array}$ & $\begin{array}{l}27 \\
\text { patients, } \\
30 \\
\text { parents }\end{array}$ & $\begin{array}{l}12- \\
23 \\
\text { year } \\
\mathrm{s}\end{array}$ & None & $\begin{array}{l}\text { Single } \\
\text { centre, } \\
\text { USA }\end{array}$ & $\begin{array}{l}\text { Over the } \\
\text { age of } 25 \\
\text { years; not } \\
\text { complete } \\
\text { d } \\
\text { treatment } \\
\text {; desire }\end{array}$ & $\mathrm{V}$ and \\
\hline $\begin{array}{l}\text { Pitak- } \\
\text { Arnnop et } \\
\text { al. (2011) }\end{array}$ & $\mathrm{T}$ & $\begin{array}{l}\text { Assessme } \\
\text { nt of } \\
\text { photograp } \\
\text { hs }\end{array}$ & $\begin{array}{l}\text { Professi } \\
\text { onals, } \\
\text { layperso } \\
\text { ns }\end{array}$ & $\begin{array}{l}50 \\
\text { patient } \\
\text { photogra } \\
\text { phs, } 51 \\
\text { professio } \\
\text { nals, } 507 \\
\text { layperson } \\
\text { s }\end{array}$ & $\begin{array}{l}15- \\
48 \\
\text { year } \\
\text { s }\end{array}$ & None & $\begin{array}{l}\text { Single } \\
\text { centre, } \\
\text { Germany }\end{array}$ & $\begin{array}{l}\text { Syndromi } \\
\text { c cleft }\end{array}$ & $\mathrm{U}$ \\
\hline $\begin{array}{l}\text { Reekie } \\
\text { (2011) }\end{array}$ & $\mathrm{T}$ & $\begin{array}{l}\text { Question } \\
\text { naires }\end{array}$ & Patients & $\begin{array}{l}15 \\
\text { patients } \\
\text { of South } \\
\text { Asian } \\
\text { ethnicity }\end{array}$ & $\begin{array}{l}16- \\
65 \\
\text { year } \\
s\end{array}$ & $\begin{array}{l}95 \\
\text { Caucasi } \\
\text { an } \\
\text { patients }\end{array}$ & $\begin{array}{l}\text { Single } \\
\text { centre, } \\
\text { UK }\end{array}$ & $\begin{array}{l}\text { Syndromi } \\
\text { c cleft; } \\
\text { mental } \\
\text { retardatio } \\
\text { n; } \\
\text { patients } \\
\text { with CP }\end{array}$ & $\mathrm{U}$ \\
\hline $\begin{array}{l}\text { Vogels et } \\
\text { al. (2011) }\end{array}$ & $\mathrm{E}$ & $\begin{array}{l}\text { Question } \\
\text { naires }\end{array}$ & $\begin{array}{l}\mathrm{Pa} \\
\mathrm{pa}\end{array}$ & $\begin{array}{l}110 \\
\text { patients }\end{array}$ & $\begin{array}{l}4-12 \\
\text { year } \\
\mathrm{s}\end{array}$ & $\begin{array}{l}\text { Norm } \\
\text { data }\end{array}$ & $\begin{array}{l}\text { Single } \\
\text { centre, } \\
\text { The } \\
\text { Netherlan } \\
\text { ds }\end{array}$ & $\mathrm{X}$ & $\begin{array}{l}\mathrm{V} \text { and } \\
\mathrm{U}\end{array}$ \\
\hline $\begin{array}{l}\text { Broder et } \\
\text { al. }(2012)\end{array}$ & & $\begin{array}{l}\text { Quest } \\
\text { naire }\end{array}$ & Patients & $\begin{array}{l}839 \\
\text { patients }\end{array}$ & $\begin{array}{l}7-19 \\
\text { year } \\
\text { s }\end{array}$ & $\begin{array}{l}\text { Norm } \\
\text { data }\end{array}$ & $\begin{array}{l}6 \text { centres, } \\
\text { USA }\end{array}$ & $\begin{array}{l}\text { Non- } \\
\text { English } \\
\text { or non- } \\
\text { Spanish } \\
\text { speaking }\end{array}$ & V \\
\hline $\begin{array}{l}\text { Collett et } \\
\text { al. (2012) }\end{array}$ & $\mathrm{E}, \mathrm{B}, \mathrm{S}$ & $\begin{array}{l}\text { Question } \\
\text { naires }\end{array}$ & Patients & $\begin{array}{l}93 \\
\text { patients }\end{array}$ & $\begin{array}{l}5-9 \\
\text { year } \\
\text { s }\end{array}$ & $\begin{array}{l}124 \\
\text { controls }\end{array}$ & $\begin{array}{l}\text { National } \\
\text { survey } \\
\text { data, USA }\end{array}$ & $\begin{array}{l}\text { Syndromi } \\
\text { c cleft; } \\
\text { Mendelia } \\
\text { n- } \\
\text { inherited } \\
\text { disorder }\end{array}$ & V \\
\hline $\begin{array}{l}\text { Gassling } \\
\text { et al. } \\
(2012)\end{array}$ & $\mathrm{E}$ & $\begin{array}{l}\text { Stress } \\
\text { test; } \\
\text { physiolog } \\
\text { ical } \\
\text { assessme } \\
\text { nt; } \\
\text { questionn }\end{array}$ & $\begin{array}{l}\text { Patients, } \\
\text { professi } \\
\text { onals }\end{array}$ & $\begin{array}{l}30 \\
\text { patients }\end{array}$ & $\begin{array}{l}18- \\
40 \\
\text { year } \\
\mathrm{s}\end{array}$ & $\begin{array}{l}30 \\
\text { controls }\end{array}$ & $\begin{array}{l}\text { Single } \\
\text { centre, } \\
\text { Germany }\end{array}$ & X & $\begin{array}{l}\mathrm{V} \text { and } \\
\mathrm{U}\end{array}$ \\
\hline
\end{tabular}




\begin{tabular}{|c|c|c|c|c|c|c|c|c|c|}
\hline & & aire & & & & & & & \\
\hline $\begin{array}{l}\text { Ha et al. } \\
(2012)\end{array}$ & $\begin{array}{l}D, B, \\
E, S\end{array}$ & $\begin{array}{l}\text { Question } \\
\text { naires }\end{array}$ & Parents & $\begin{array}{l}93 \\
\text { patients }\end{array}$ & $\begin{array}{l}6-11 \\
\text { year } \\
\text { s }\end{array}$ & $\begin{array}{l}100 \\
\text { controls }\end{array}$ & $\begin{array}{l}\text { Single } \\
\text { centre, } \\
\text { China }\end{array}$ & $\begin{array}{l}\text { CP; other } \\
\text { abnormal } \\
\text { ities or } \\
\text { health } \\
\text { problems }\end{array}$ & V \\
\hline $\begin{array}{l}\text { Hall et al. } \\
(2012)\end{array}$ & $\mathrm{E}, \mathrm{T}$ & $\begin{array}{l}\text { Semi- } \\
\text { structured } \\
\text { interview } \\
\text { and } \\
\text { participat } \\
\text { ory } \\
\text { activities }\end{array}$ & Patients & $\begin{array}{l}17 \\
\text { patients }\end{array}$ & $\begin{array}{l}8-17 \\
\text { year } \\
\text { s }\end{array}$ & None & $\begin{array}{l}\text { Single } \\
\text { centre, } \\
\text { UK }\end{array}$ & $\begin{array}{l}\text { Learning } \\
\text { disability; } \\
\text { significan } \\
\text { t medical } \\
\text { history; } \\
\text { non- } \\
\text { English }\end{array}$ & $\begin{array}{l}\text { Thema } \\
\text { tic } \\
\text { analysi } \\
\text { s }\end{array}$ \\
\hline $\begin{array}{l}\text { Montiros } \\
\text { so et al. } \\
(2012)\end{array}$ & $S$ & $\begin{array}{l}\text { Question } \\
\text { naires; } \\
\text { observati } \\
\text { on }\end{array}$ & $\begin{array}{l}\text { Patients, } \\
\text { professi } \\
\text { onals }\end{array}$ & $\begin{array}{l}25 \\
\text { patients }\end{array}$ & $\begin{array}{l}2 \\
\text { mont } \\
\text { hs }\end{array}$ & $\begin{array}{l}25 \\
\text { controls }\end{array}$ & gle & $\begin{array}{l}\text { Prematuri } \\
\text { ty; low } \\
\text { birth } \\
\text { weight; } \\
\text { syndromi } \\
\text { c cleft }\end{array}$ & $\begin{array}{l}\mathrm{V} \text { and } \\
\mathrm{U}\end{array}$ \\
\hline $\begin{array}{l}\text { O'Hanlon } \\
\text { et al. } \\
(2012)\end{array}$ & $\mathrm{E}, \mathrm{S}$ & $\begin{array}{l}\text { Question } \\
\text { naires, } \\
\text { open- } \\
\text { ended } \\
\text { questions }\end{array}$ & $\begin{array}{l}\text { Patients, } \\
\text { parents }\end{array}$ & $\begin{array}{l}27 \\
\text { parents } \\
\text { with cleft }\end{array}$ & $\begin{array}{l}45 \\
\text { year }\end{array}$ & $\begin{array}{l}27 \\
\text { parents } \\
\text { without } \\
\text { cleft }\end{array}$ & $\begin{array}{l}\text { Single } \\
\text { centre, } \\
\text { UK }\end{array}$ & $\begin{array}{l}\text { Another } \\
\text { immediat } \\
\text { e family } \\
\text { member } \\
\text { with cleft }\end{array}$ & $\begin{array}{l}\mathrm{V} \text { and } \\
\mathrm{U}\end{array}$ \\
\hline $\begin{array}{l}\text { Papaman } \\
\text { ou et al. } \\
(2012)\end{array}$ & $\mathrm{T}$ & $\begin{array}{l}\text { Assessme } \\
\text { nt of } \\
\text { photograp } \\
\text { hs }\end{array}$ & $\begin{array}{l}\text { Laypers } \\
\text { ons, } \\
\text { professi } \\
\text { onals }\end{array}$ & $\begin{array}{l}\text { 12 UCLP } \\
\text { patient } \\
\text { photogra } \\
\text { phs, } 12 \\
\text { layperson } \\
\text { s, } 12 \\
\text { orthodont } \\
\text { ists, } 12 \\
\text { surgeons }\end{array}$ & $\begin{array}{l}17- \\
27 \\
\text { year } \\
\text { s }\end{array}$ & None & $\begin{array}{l}\text { Single } \\
\text { centre, } \\
\text { Greece }\end{array}$ & $\begin{array}{l}\text { Professio } \\
\text { nals with } \\
\text { less than } \\
10 \text { years' } \\
\text { experienc } \\
\text { e }\end{array}$ & $\mathrm{U}$ \\
\hline $\begin{array}{l}\text { Van } \\
\text { Lierde et } \\
\text { al. (2012) }\end{array}$ & $\mathrm{S}, \mathrm{T}$ & $\begin{array}{l}\text { Question } \\
\text { naire }\end{array}$ & $\begin{array}{l}\text { Patients, } \\
\text { parents }\end{array}$ & 43 UCLP & $\begin{array}{l}10- \\
17 \\
\text { year } \\
\text { s }\end{array}$ & $\begin{array}{l}43 \\
\text { controls }\end{array}$ & $\begin{array}{l}\text { Single } \\
\text { centre, } \\
\text { Belgium }\end{array}$ & $\begin{array}{l}\text { Syndromi } \\
\text { c cleft; } \\
\text { cognitive } \\
\text { deficienc } \\
\text { y; } \\
\text { neuromot } \\
\text { or } \\
\text { dysfuncti } \\
\text { on; } \\
\text { residual } \\
\text { hard } \\
\text { palate } \\
\text { fistula; } \\
\text { hearing } \\
\text { threshold } \\
\text { s below } \\
\text { 20db in } \\
\text { the }\end{array}$ & $\mathrm{U}$ \\
\hline
\end{tabular}




\begin{tabular}{|c|c|c|c|c|c|c|c|c|c|}
\hline & & & & & & & & $\begin{array}{l}\text { poorer } \\
\text { ear }\end{array}$ & \\
\hline $\begin{array}{l}\text { Wehby et } \\
\text { al. (2012) }\end{array}$ & $\mathrm{D}, \mathrm{B}, \mathrm{E}$ & $\begin{array}{l}\text { Structure } \\
\mathrm{d} \\
\text { interview }\end{array}$ & Parents & $\begin{array}{l}104 \\
\text { mothers }\end{array}$ & $\begin{array}{l}2-12 \\
\text { year } \\
\mathrm{s}\end{array}$ & $\begin{array}{l}\text { Norm } \\
\text { data }\end{array}$ & $\begin{array}{l}\text { Registry } \\
\text { data, USA }\end{array}$ & $\begin{array}{l}\text { Syndromi } \\
\text { c cleft }\end{array}$ & V \\
\hline $\begin{array}{l}\text { Young et } \\
\text { al. (2012) }\end{array}$ & D & $\begin{array}{l}\text { Cognitive } \\
\text { assessme } \\
\text { nt }\end{array}$ & $\begin{array}{l}\text { Professi } \\
\text { onals }\end{array}$ & $\begin{array}{l}86 \\
\text { patients }\end{array}$ & $\begin{array}{l}3-6 \\
\text { year } \\
\text { s }\end{array}$ & $\begin{array}{l}100 \\
\text { controls }\end{array}$ & $\begin{array}{l}\text { Single } \\
\text { centre, } \\
\text { Singapore }\end{array}$ & $\begin{array}{l}\text { Failed } \\
\text { hearing } \\
\text { screening }\end{array}$ & $\mathrm{V}$ \\
\hline $\begin{array}{l}\text { Abd- } \\
\text { Elsayed } \\
\text { et al. } \\
\text { (2013) }\end{array}$ & $\mathrm{E}$ & $\begin{array}{l}\text { Participat } \\
\text { ory } \\
\text { activities }\end{array}$ & $\begin{array}{l}\text { Patients, } \\
\text { professi } \\
\text { onals }\end{array}$ & $\begin{array}{l}171 \\
\text { patients }\end{array}$ & $\begin{array}{l}5-17 \\
\text { year } \\
\text { s }\end{array}$ & None & $\begin{array}{l}\text { Medical } \\
\text { mission, } \\
22 \\
\text { countries } \\
\text { (majority } \\
\text { USA and } \\
\text { Canada) }\end{array}$ & & $\mathrm{U}$ \\
\hline $\begin{array}{l}\text { Alansari } \\
\text { et al. } \\
(2013)\end{array}$ & E, S, T & $\begin{array}{l}\text { Semi- } \\
\text { structured } \\
\text { interview }\end{array}$ & Patients & $\begin{array}{l}11 \text { UCLP } \\
\text { and } \\
\text { BCLP } \\
\text { patients }\end{array}$ & $\begin{array}{l}19- \\
54 \\
\text { year } \\
\text { s }\end{array}$ & & $\begin{array}{l}\text { Non- } \\
\text { profit } \\
\text { organisati } \\
\text { on, } 3 \\
\text { cities in } \\
\text { Canada }\end{array}$ & $\begin{array}{l}\text { Syndromi } \\
\text { c cleft; } \\
\text { incomplet } \\
\text { e cleft; } \\
\text { under } 18 \\
\text { years of } \\
\text { age; non- } \\
\text { English } \\
\text { speaking }\end{array}$ & $\begin{array}{l}\text { Groun } \\
\text { ded } \\
\text { Theory }\end{array}$ \\
\hline $\begin{array}{l}\text { Dogan et } \\
\text { al. (2013) }\end{array}$ & $\mathrm{E}$ & $\begin{array}{l}\text { Question } \\
\text { naires }\end{array}$ & Patients & patients & $\begin{array}{l}12 \\
\text { year } \\
\mathrm{s}\end{array}$ & $\begin{array}{l}15 \\
\text { controls }\end{array}$ & $\begin{array}{l}\text { Single } \\
\text { centre, } \\
\text { Turkey }\end{array}$ & $\mathrm{x}$ & V \\
\hline $\begin{array}{l}\text { Eslami et } \\
\text { al. (2013) }\end{array}$ & E & $\begin{array}{l}\text { Question } \\
\text { naire }\end{array}$ & & $\begin{array}{l}50 \\
\text { patients }\end{array}$ & $\begin{array}{l}8-12 \\
\text { year } \\
\mathrm{s}\end{array}$ & $\begin{array}{l}\text { Norm } \\
\text { data }\end{array}$ & $\begin{array}{l}\text { Single } \\
\text { centre, } \\
\text { Iran }\end{array}$ & $\mathrm{x}$ & $\mathrm{V}$ \\
\hline $\begin{array}{l}\text { Foo et al. } \\
(2013)\end{array}$ & & $\begin{array}{l}\text { Assessme } \\
\text { nt of } \\
\text { photograp } \\
\text { hs }\end{array}$ & $\begin{array}{l}\text { Patients, } \\
\text { layperso } \\
\text { ns, } \\
\text { professi } \\
\text { onals }\end{array}$ & $\begin{array}{l}80 \\
\text { patient } \\
\text { photogra } \\
\text { phs, } 2 \\
\text { patients, } \\
2 \\
\text { layperson } \\
\text { s, } 5 \\
\text { professio } \\
\text { nals }\end{array}$ & $\begin{array}{l}18- \\
64 \\
\text { year } \\
\text { s }\end{array}$ & None & $\begin{array}{l}\text { Single } \\
\text { centre, } \\
\text { Australia }\end{array}$ & $\begin{array}{l}\text { Syndromi } \\
\text { c cleft; } \\
\text { under } 18 \\
\text { years of } \\
\text { age; not } \\
\text { complete } \\
\text { d } \\
\text { treatment } \\
\text {; not } \\
\text { treated at } \\
\text { a single } \\
\text { centre }\end{array}$ & $\mathrm{U}$ \\
\hline $\begin{array}{l}\text { Gkantidis } \\
\text { et al. } \\
(2013)\end{array}$ & $\mathrm{D}, \mathrm{S}, \mathrm{T}$ & $\begin{array}{l}\text { Assessme } \\
\text { nt of } \\
\text { photograp } \\
\text { hs }\end{array}$ & $\begin{array}{l}\text { Patients, } \\
\text { parents, } \\
\text { layperso } \\
\text { ns, } \\
\text { professi } \\
\text { onals }\end{array}$ & $\begin{array}{l}12 \text { UCLP } \\
\text { patients, } \\
12 \\
\text { parents, } \\
12 \\
\text { layperson } \\
\text { s, } 12 \\
\text { professio }\end{array}$ & $\begin{array}{l}17- \\
27 \\
\text { year } \\
\text { s }\end{array}$ & None & $\begin{array}{l}\text { Single } \\
\text { centre, } \\
\text { Greece }\end{array}$ & $\begin{array}{l}\text { Professio } \\
\text { nals with } \\
\text { less than } \\
10 \text { years' } \\
\text { experienc } \\
\text { e }\end{array}$ & $\mathrm{U}$ \\
\hline
\end{tabular}




\begin{tabular}{|c|c|c|c|c|c|c|c|c|c|}
\hline & & & & nals & & & & & \\
\hline $\begin{array}{l}\text { Hall et al. } \\
(2013)\end{array}$ & $\mathrm{E}, \mathrm{S}, \mathrm{T}$ & $\begin{array}{l}\text { Semi- } \\
\text { structured } \\
\text { interview; } \\
\text { participat } \\
\text { ory } \\
\text { activities }\end{array}$ & Patients & $\begin{array}{l}17 \\
\text { patients }\end{array}$ & $\begin{array}{l}8-17 \\
\text { year } \\
\text { s }\end{array}$ & None & $\begin{array}{l}\text { Single } \\
\text { centre, } \\
\text { UK }\end{array}$ & $\begin{array}{l}\text { Learning } \\
\text { disability; } \\
\text { significan } \\
\text { t medical } \\
\text { history; } \\
\text { not fluent } \\
\text { in } \\
\text { English }\end{array}$ & $\begin{array}{l}\text { Narrati } \\
\text { ve }\end{array}$ \\
\hline $\begin{array}{l}\text { Mani et } \\
\text { al. (2013) }\end{array}$ & $\mathrm{E}, \mathrm{T}$ & $\begin{array}{l}\text { Question } \\
\text { naires; } \\
\text { assessme } \\
\text { nt of } \\
\text { photograp } \\
\text { hs }\end{array}$ & $\begin{array}{l}\text { Patients, } \\
\text { professi } \\
\text { onals }\end{array}$ & $\begin{array}{l}86 \text { UCLP } \\
\text { patients }\end{array}$ & $\begin{array}{l}20- \\
47 \\
\text { year } \\
\text { s }\end{array}$ & $\begin{array}{l}\text { Norm } \\
\text { data }\end{array}$ & $\begin{array}{l}\text { Single } \\
\text { centre, } \\
\text { Sweden }\end{array}$ & $\begin{array}{l}\text { Syndromi } \\
\text { c cleft; } \\
\text { incomplet } \\
\text { e cleft; } \\
\text { major } \\
\text { mental or } \\
\text { physical } \\
\text { incapacit }\end{array}$ & $\mathrm{V}$ and \\
\hline $\begin{array}{l}\text { Millar et } \\
\text { al. (2013) }\end{array}$ & $\begin{array}{l}\mathrm{D}, \mathrm{B}, \\
\mathrm{E}, \mathrm{T}\end{array}$ & $\begin{array}{l}\text { 3D } \\
\text { imaging; } \\
\text { questionn } \\
\text { aire }\end{array}$ & $\begin{array}{l}\text { Patients, } \\
\text { parents, } \\
\text { professi } \\
\text { onals }\end{array}$ & $\begin{array}{l}94 \\
\text { patients }\end{array}$ & $\begin{array}{l}10 \\
\text { year } \\
\text { s }\end{array}$ & controls & $\begin{array}{l}\text { Single } \\
\text { centre, } \\
\text { UK }\end{array}$ & $\begin{array}{l}\text { English is } \\
\text { not first } \\
\text { language }\end{array}$ & $\mathrm{V}$ \\
\hline $\begin{array}{l}\text { Nkenke } \\
\text { et al. } \\
\text { (2013) }\end{array}$ & $\mathrm{T}$ & $\begin{array}{l}\text { Question } \\
\text { naire }\end{array}$ & Patients & $\begin{array}{l}362 \\
\text { patient }\end{array}$ & $\begin{array}{l}6-18 \\
\text { year } \\
\text { s }\end{array}$ & None & $\begin{array}{l}\text { Single } \\
\text { centre, } \\
\text { Germany }\end{array}$ & $\mathrm{x}$ & $\mathrm{U}$ \\
\hline $\begin{array}{l}\text { Tannure } \\
\text { et al. } \\
(2013)\end{array}$ & $\mathrm{G}$ & $\begin{array}{l}\text { Structure } \\
\text { d } \\
\text { interview }\end{array}$ & & $\begin{array}{l}35 \\
\text { patients }\end{array}$ & $\begin{array}{l}5-12 \\
\text { year } \\
\mathrm{s}\end{array}$ & $\begin{array}{l}35 \\
\text { controls }\end{array}$ & $\begin{array}{l}\text { Single } \\
\text { centre, } \\
\text { Brazil }\end{array}$ & $\begin{array}{l}\text { Clinically } \\
\text { or } \\
\text { geneticall } \\
\text { y } \\
\text { diagnose } \\
\text { d } \\
\text { syndrome }\end{array}$ & $\mathrm{V}$ \\
\hline $\begin{array}{l}\text { Tiemens } \\
\text { et al. } \\
(2013)\end{array}$ & $\mathrm{T}$ & $\begin{array}{l}\text { Semi- } \\
\text { structured } \\
\text { interview } \\
\mathrm{s}\end{array}$ & Patients & $\begin{array}{l}7 \text { female } \\
\text { patients }\end{array}$ & $\begin{array}{l}15- \\
20 \\
\text { year } \\
\text { s }\end{array}$ & None & $\begin{array}{l}\text { Single } \\
\text { centre, } \\
\text { Canada }\end{array}$ & $\begin{array}{l}\text { Not } \\
\text { scheduled } \\
\text { for } \\
\text { orthognat } \\
\text { hic } \\
\text { surgery }\end{array}$ & IPA \\
\hline $\begin{array}{l}\text { Tyler et } \\
\text { al. (2013) }\end{array}$ & $\mathrm{S}, \mathrm{T}$ & $\begin{array}{l}\text { Question } \\
\text { naires }\end{array}$ & Parents & $\begin{array}{l}271 \\
\text { mothers, } \\
8 \text { fathers }\end{array}$ & $\begin{array}{l}4-9 \\
\text { year } \\
\mathrm{s}\end{array}$ & $\begin{array}{l}\text { Norm } \\
\text { data }\end{array}$ & $\begin{array}{l}3 \text { centres, } \\
\text { USA }\end{array}$ & $\begin{array}{l}\text { No longer } \\
\text { living } \\
\text { with } \\
\text { biological } \\
\text { parent; } \\
\text { developm } \\
\text { ental } \\
\text { delay or } \\
\text { mental } \\
\text { retardatio } \\
\mathrm{n}\end{array}$ & $\begin{array}{l}\mathrm{V} \text { and } \\
\mathrm{U}\end{array}$ \\
\hline
\end{tabular}




\begin{tabular}{|c|c|c|c|c|c|c|c|c|c|}
\hline $\begin{array}{l}\text { Van der } \\
\text { Plas et al. } \\
\text { (2013) }\end{array}$ & $\mathrm{D}, \mathrm{E}, \mathrm{S}$ & $\begin{array}{l}\text { Question } \\
\text { naires; } \\
\text { education } \\
\text { al } \\
\text { records; } \\
\text { eye- } \\
\text { tracking; } \\
\text { emotional } \\
\text { response; } \\
\text { physiolog } \\
\text { ical } \\
\text { assessme } \\
\text { nt }\end{array}$ & $\begin{array}{l}\text { Patients, } \\
\text { professi } \\
\text { onals }\end{array}$ & $\begin{array}{l}20 \text { male } \\
\text { patients }\end{array}$ & $\begin{array}{l}13- \\
25 \\
\text { year } \\
\text { s }\end{array}$ & $\begin{array}{l}20 \\
\text { controls }\end{array}$ & $\begin{array}{l}\text { Single } \\
\text { centre, } \\
\text { USA }\end{array}$ & $\begin{array}{l}\text { Syndromi } \\
\text { c cleft; } \\
\text { history of } \\
\text { severe } \\
\text { hearing } \\
\text { loss } \\
\text { requiring } \\
\text { a hearing } \\
\text { aid; IQ } \\
\text { lower } \\
\text { than } 70 \text {; } \\
\text { history of } \\
\text { epilepsy, } \\
\text { brain } \\
\text { trauma or } \\
\text { brain } \\
\text { tumour }\end{array}$ & V \\
\hline $\begin{array}{l}\text { Watterso } \\
\mathrm{n} \mathrm{et} \mathrm{al.} \\
(2013)\end{array}$ & E, $T$ & $\begin{array}{l}\text { Speech } \\
\text { assessme } \\
\text { nt }\end{array}$ & $\begin{array}{l}\text { Professi } \\
\text { onals, } \\
\text { layperso } \\
\text { ns }\end{array}$ & $\begin{array}{l}7 \\
\text { patients, } \\
44 \\
\text { layperson } \\
\text { s, } 1 \\
\text { professio } \\
\text { nal }\end{array}$ & $\begin{array}{l}8-11 \\
\text { year } \\
\mathrm{s}\end{array}$ & $\begin{array}{l}3 \\
\text { siblings }\end{array}$ & $\begin{array}{l}\text { Single } \\
\text { centre, } \\
\text { UK }\end{array}$ & $\mathrm{x}$ & $\mathrm{U}$ \\
\hline $\begin{array}{l}\text { Yunusa } \\
\& \\
\text { Obembe } \\
(2013)\end{array}$ & E & $\begin{array}{l}\text { Question } \\
\text { naires }\end{array}$ & Patients & $\begin{array}{l}200 \\
\text { patients }\end{array}$ & $\begin{array}{l}20- \\
39 \\
\text { year } \\
\text { s }\end{array}$ & $\begin{array}{l}\text { Norm } \\
\text { data }\end{array}$ & $\begin{array}{l}\text { Single } \\
\text { centre, } \\
\text { Nigeria }\end{array}$ & $\begin{array}{l}\text { Presence } \\
\text { of overt } \\
\text { or past } \\
\text { psychiatri } \\
\text { c ailment; } \\
\text { poor level } \\
\text { of } \\
\text { literacy }\end{array}$ & $\begin{array}{l}\mathrm{V} \text { and } \\
\mathrm{U}\end{array}$ \\
\hline $\begin{array}{l}\text { Adamson } \\
\text { et al. } \\
\text { (2014) }\end{array}$ & D & $\begin{array}{l}\text { Neuroima } \\
\text { ging }\end{array}$ & $\begin{array}{l}\text { Professi } \\
\text { onals }\end{array}$ & $\begin{array}{l}26 \\
\text { patients }\end{array}$ & $\begin{array}{l}6-14 \\
\text { year } \\
\text { s }\end{array}$ & $\begin{array}{l}26 \\
\text { controls }\end{array}$ & $\begin{array}{l}\text { Single } \\
\text { centre, } \\
\text { Australia }\end{array}$ & $\begin{array}{l}\text { Syndromi } \\
\text { c cleft; } \\
\text { complex } \\
\text { medical } \\
\text { condition }\end{array}$ & N/A \\
\hline $\begin{array}{l}\text { Broder, } \\
\text { Wilson- } \\
\text { Gendero } \\
\text { n \& } \\
\text { Sischo } \\
(2014)\end{array}$ & $\mathrm{E}, \mathrm{T}$ & $\begin{array}{l}\text { Question } \\
\text { naires }\end{array}$ & Patients & $\begin{array}{l}1,200 \\
\text { patients }\end{array}$ & $\begin{array}{l}7-18 \\
\text { year } \\
\text { s }\end{array}$ & $\begin{array}{l}\text { Norm } \\
\text { data }\end{array}$ & $\begin{array}{l}6 \text { centres, } \\
\text { USA }\end{array}$ & $\begin{array}{l}\text { Non- } \\
\text { English } \\
\text { or non- } \\
\text { Spanish } \\
\text { speaking }\end{array}$ & $\mathrm{V}$ \\
\hline $\begin{array}{l}\text { Broder,, } \\
\text { Wilson- } \\
\text { Genderso } \\
\text { n, Sischo } \\
\text { et al. } \\
\text { (2014) }\end{array}$ & $\mathrm{T}, \mathrm{G}$ & $\begin{array}{l}\text { Question } \\
\text { naire }\end{array}$ & Patients & $\begin{array}{l}1,200 \\
\text { patients }\end{array}$ & $\begin{array}{l}7-19 \\
\text { year } \\
\mathrm{s}\end{array}$ & $\begin{array}{l}\text { Norm } \\
\text { data }\end{array}$ & $\begin{array}{l}6 \text { centres, } \\
\text { USA }\end{array}$ & $\begin{array}{l}\text { Non- } \\
\text { English } \\
\text { or non- } \\
\text { Spanish } \\
\text { speaking }\end{array}$ & V \\
\hline $\begin{array}{l}\text { Burnell et } \\
\text { al. (2014) }\end{array}$ & D & $\begin{array}{l}\text { Retrospec } \\
\text { tive } \\
\text { clinical }\end{array}$ & $\begin{array}{l}\text { Professi } \\
\text { onals }\end{array}$ & $\begin{array}{l}81 \\
\text { patients }\end{array}$ & $\begin{array}{l}2+ \\
\text { year }\end{array}$ & None & $\begin{array}{l}\text { Single } \\
\text { centre, }\end{array}$ & $\begin{array}{l}\text { Less than } \\
2 \text { years' } \\
\text { follow-up }\end{array}$ & N/A \\
\hline
\end{tabular}




\begin{tabular}{|c|c|c|c|c|c|c|c|c|c|}
\hline & & review & & & $\mathrm{s}$ & & Canada & data & \\
\hline $\begin{array}{l}\text { Byrne et } \\
\text { al. (2014) }\end{array}$ & $\mathrm{T}$ & $\begin{array}{l}\text { Question } \\
\text { naire; } \\
\text { open- } \\
\text { ended } \\
\text { questions; } \\
\text { assessme } \\
\text { nt of } \\
\text { photograp } \\
\text { hs }\end{array}$ & $\begin{array}{l}\text { Patients, } \\
\text { professi } \\
\text { onals }\end{array}$ & $\begin{array}{l}35 \\
\text { patients, } \\
45 \\
\text { professio } \\
\text { nals }\end{array}$ & $\begin{array}{l}14- \\
53 \\
\text { year } \\
\text { s }\end{array}$ & None & $\begin{array}{l}\text { Single } \\
\text { centre, } \\
\text { Ireland }\end{array}$ & $\begin{array}{l}\text { Not } \\
\text { requiring } \\
\text { secondar } \\
\text { y } \\
\text { rhinoplast } \\
\text { y }\end{array}$ & $\begin{array}{l}\mathrm{V} \text { and } \\
\mathrm{U}\end{array}$ \\
\hline $\begin{array}{l}\text { Collett et } \\
\text { al. (2014) }\end{array}$ & D & $\begin{array}{l}\text { Education } \\
\text { al records }\end{array}$ & $\begin{array}{l}\text { Professi } \\
\text { onals }\end{array}$ & $\begin{array}{l}256 \\
\text { patients }\end{array}$ & $\begin{array}{l}7-19 \\
\text { year } \\
\text { s }\end{array}$ & $\begin{array}{l}387 \\
\text { unaffect } \\
\text { ed } \\
\text { siblings }\end{array}$ & $\begin{array}{l}\text { Registry, } \\
\text { USA }\end{array}$ & $\begin{array}{l}\text { Syndromi } \\
\text { c cleft; } \\
\text { non- } \\
\text { biological } \\
\text { siblings }\end{array}$ & N/A \\
\hline $\begin{array}{l}\text { Conrad et } \\
\text { al. (2014) }\end{array}$ & $\mathrm{D}, \mathrm{B}$ & $\begin{array}{l}\text { Cognitive } \\
\text { assessme } \\
\text { nt }\end{array}$ & $\begin{array}{l}\text { Professi } \\
\text { onals }\end{array}$ & $\begin{array}{l}80 \\
\text { patients }\end{array}$ & ye & controls & $\begin{array}{l}\text { Single } \\
\text { centre, } \\
\text { USA }\end{array}$ & $\begin{array}{l}\text { Head } \\
\text { trauma; } \\
\text { major } \\
\text { medical } \\
\text { disorder; } \\
\text { English } \\
\text { not } \\
\text { dominant } \\
\text { language; } \\
\text { learning } \\
\text { disabilitie } \\
\text { s; } \\
\text { exception } \\
\text { al } \\
\text { achievem } \\
\text { ent }\end{array}$ & V \\
\hline $\begin{array}{l}\text { Eichenbe } \\
\text { rger et al. } \\
(2014)\end{array}$ & $\mathrm{T}$ & $\begin{array}{l}\text { Assessme } \\
\text { nt of } \\
\text { photograp } \\
\text { hs }\end{array}$ & $\begin{array}{l}\text { Laypers } \\
\text { ons, } \\
\text { professi } \\
\text { onals }\end{array}$ & $\begin{array}{l}20 \\
\text { patients }\end{array}$ & $\begin{array}{l}\mathrm{M}= \\
20.5 \\
\text { year } \\
\mathrm{s}\end{array}$ & $\begin{array}{l}10 \\
\text { patients } \\
\text { with } \\
\text { Class I } \\
\text { occlusio } \\
\text { n }\end{array}$ & $\begin{array}{l}\text { Single } \\
\text { centre, } \\
\text { Switzerla } \\
\text { nd }\end{array}$ & $\begin{array}{l}\text { Syndromi } \\
\text { c cleft; } \\
\text { other } \\
\text { congenita } \\
\text { l } \\
\text { anomalie } \\
\text { s; } \\
\text { outstandi } \\
\text { ng facial } \\
\text { characteri } \\
\text { stics; } \\
\text { incomplet } \\
\text { e records; } \\
\text { not } \\
\text { complete } \\
\text { d } \\
\text { recomme } \\
\text { nded } \\
\text { treatment }\end{array}$ & $\mathrm{U}$ \\
\hline $\begin{array}{l}\text { Feragen, } \\
\text { Stock \& }\end{array}$ & D & $\begin{array}{l}\text { Question } \\
\text { naires; }\end{array}$ & Patients & $\begin{array}{l}754 \\
\text { patients, }\end{array}$ & $\begin{array}{l}10 \\
\text { year }\end{array}$ & $\begin{array}{l}\text { Norm } \\
\text { data }\end{array}$ & $\begin{array}{l}\text { Single } \\
\text { centre, }\end{array}$ & $\begin{array}{l}\text { Severe } \\
\text { developm }\end{array}$ & V \\
\hline
\end{tabular}




\begin{tabular}{|c|c|c|c|c|c|c|c|c|c|}
\hline $\begin{array}{l}\text { Rumsey } \\
\text { (2014) }\end{array}$ & & $\begin{array}{l}\text { retrospect } \\
\text { ive } \\
\text { clinical } \\
\text { review }\end{array}$ & & $\begin{array}{l}169 \text { with } \\
\text { psycholo } \\
\text { gy data }\end{array}$ & $\mathrm{s}$ & & Norway & $\begin{array}{l}\text { ental } \\
\text { problems } \\
\text { resulting } \\
\text { in } \\
\text { incomplet } \\
\text { e data }\end{array}$ & \\
\hline $\begin{array}{l}\text { Feragen } \\
\& \text { Stock } \\
(2014)\end{array}$ & $\begin{array}{l}D, B, \\
E, S\end{array}$ & $\begin{array}{l}\text { Question } \\
\text { naires; } \\
\text { retrospect } \\
\text { ive } \\
\text { clinical } \\
\text { review }\end{array}$ & Patients & $\begin{array}{l}205 \\
\text { patients }\end{array}$ & $\begin{array}{l}10 \\
\text { year } \\
\mathrm{s}\end{array}$ & $\begin{array}{l}\text { Norm } \\
\text { data }\end{array}$ & $\begin{array}{l}\text { Single } \\
\text { centre, } \\
\text { Norway }\end{array}$ & $\begin{array}{l}\text { Severe } \\
\text { developm } \\
\text { ental } \\
\text { problems } \\
\text { resulting } \\
\text { in } \\
\text { incomplet }\end{array}$ & \\
\hline $\begin{array}{l}\text { Gassling, } \\
\text { Christoph } \\
\text { et al. } \\
(2014)\end{array}$ & $S$ & $\begin{array}{l}\text { Observati } \\
\text { on }\end{array}$ & $\begin{array}{l}\text { Professi } \\
\text { onals }\end{array}$ & $\begin{array}{l}15 \\
\text { patients }\end{array}$ & $\begin{array}{l}8-12 \\
\text { year } \\
\mathrm{s}\end{array}$ & $\begin{array}{l}20 \\
\text { controls } \\
, 20 \\
\text { migrain } \\
\mathrm{e}\end{array}$ & $\begin{array}{l}\text { Single } \\
\text { centre, } \\
\text { Germany }\end{array}$ & $\begin{array}{l}\text { Syndromi } \\
\text { c cleft }\end{array}$ & $\mathrm{U}$ \\
\hline $\begin{array}{l}\text { Gassling, } \\
\text { Kessler et } \\
\text { al. (2014) }\end{array}$ & $\mathrm{E}, \mathrm{S}$ & $\begin{array}{l}\text { Question } \\
\text { naire; } \\
\text { emotional } \\
\text { response }\end{array}$ & $\begin{array}{l}\text { Patients, } \\
\text { professi } \\
\text { onals }\end{array}$ & $\begin{array}{l}25 \\
\text { patients }\end{array}$ & $\begin{array}{l}18- \\
40 \\
\text { year }\end{array}$ & $\frac{25}{\text { controls }}$ & $\begin{array}{l}\text { Single } \\
\text { centre, } \\
\text { Germany }\end{array}$ & $\begin{array}{l}\text { Psychiatri } \\
\text { c } \\
\text { comorbid } \\
\text { ity }\end{array}$ & V \\
\hline $\begin{array}{l}\text { Pisula et } \\
\text { al. (2014) }\end{array}$ & $\mathrm{E}, \mathrm{G}$ & $\begin{array}{l}\text { Question } \\
\text { naires }\end{array}$ & & $\begin{array}{l}48 \\
\text { patients }\end{array}$ & $\begin{array}{l}16- \\
23 \\
\text { year } \\
\text { s }\end{array}$ & $\begin{array}{l}48 \\
\text { controls }\end{array}$ & $\begin{array}{l}\text { Single } \\
\text { centre, } \\
\text { Poland }\end{array}$ & $\begin{array}{l}\text { Under } 16 \\
\text { years of } \\
\text { age; } \\
\text { syndromi } \\
\text { c cleft; } \\
\text { intellectu } \\
\text { al or } \\
\text { learning } \\
\text { disability }\end{array}$ & V \\
\hline $\begin{array}{l}\text { Smith et } \\
\text { al. (2014) }\end{array}$ & $\mathrm{E}$ & $\begin{array}{l}\text { Medical } \\
\text { assessme } \\
\text { nt; } \\
\text { longitudi } \\
\text { nal; } \\
\text { cognitive } \\
\text { assessme } \\
\text { nt }\end{array}$ & $\begin{array}{l}\text { Professi } \\
\text { onals }\end{array}$ & $\begin{array}{l}33 \\
\text { patients }\end{array}$ & $\begin{array}{l}3 \\
\text { year } \\
\text { s }\end{array}$ & $\begin{array}{l}\text { Norm } \\
\text { data }\end{array}$ & $\begin{array}{l}\text { Single } \\
\text { centre, } \\
\text { Canada }\end{array}$ & $\begin{array}{l}\text { Medicall } \\
\text { y } \\
\text { unstable; } \\
\text { required } \\
\text { previous } \\
\text { medical } \\
\text { interventi } \\
\text { ons }\end{array}$ & V \\
\hline $\begin{array}{l}\text { Wehby, } \\
\text { Collett et } \\
\text { al. (2014) }\end{array}$ & $\mathrm{D}$ & $\begin{array}{l}\text { Education } \\
\text { al records }\end{array}$ & $\begin{array}{l}\text { Professi } \\
\text { onals }\end{array}$ & $\begin{array}{l}588 \\
\text { patients }\end{array}$ & $\begin{array}{l}7-16 \\
\text { year } \\
\text { s }\end{array}$ & Registry & $\begin{array}{l}\text { Registry } \\
\text { data, USA }\end{array}$ & $\begin{array}{l}\text { Syndromi } \\
\text { c cleft }\end{array}$ & N/A \\
\hline $\begin{array}{l}\text { Wehby, } \\
\text { Nyarko et } \\
\text { al. (2014) }\end{array}$ & $\mathrm{E}$ & $\begin{array}{l}\text { Question } \\
\text { naires }\end{array}$ & Patients & $\begin{array}{l}182 \\
\text { parents } \\
\text { with cleft }\end{array}$ & $\begin{array}{l}27- \\
30 \\
\text { year } \\
\text { s }\end{array}$ & $\operatorname{Reg}$ & $\begin{array}{l}\text { National } \\
\text { survey, } \\
\text { Brazil }\end{array}$ & $\begin{array}{l}\text { No } \\
\text { children } \\
\text { at time of } \\
\text { enrolmen } \\
t\end{array}$ & V \\
\hline Crerand & $\mathrm{S}$ & Question & Parents & 1,200 & $7-18$ & Norm & 6 centres, & Non- & $\mathrm{V}$ and \\
\hline
\end{tabular}




\begin{tabular}{|c|c|c|c|c|c|c|c|c|c|}
\hline $\begin{array}{l}\text { et al. } \\
\text { (2015) }\end{array}$ & & naires & & parents & $\begin{array}{l}\text { year } \\
\mathrm{s}\end{array}$ & data & USA & $\begin{array}{l}\text { English } \\
\text { or } \\
\text { Spanish } \\
\text { speaking; } \\
\text { inability } \\
\text { to read at } \\
\text { second } \\
\text { grade } \\
\text { level; } \\
\text { craniofaci } \\
\text { al } \\
\text { syndrome } \\
\text {; complex } \\
\text { medical } \\
\text { condition }\end{array}$ & $\mathrm{U}$ \\
\hline $\begin{array}{l}\text { Feragen } \\
\text { et al. } \\
\text { (2015) }\end{array}$ & $\begin{array}{l}\text { D, B, } \\
\text { E, S }\end{array}$ & $\begin{array}{l}\text { Question } \\
\text { naires }\end{array}$ & $\begin{array}{l}\text { Patients, } \\
\text { parents }\end{array}$ & $\begin{array}{l}857 \\
\text { patients, } \\
304 \\
\text { caregiver } \\
\text { s }\end{array}$ & $\begin{array}{l}16 \\
\text { year } \\
\text { s }\end{array}$ & $\begin{array}{l}\text { Norm } \\
\text { data }\end{array}$ & $\begin{array}{l}\text { Single } \\
\text { centre, } \\
\text { Norway }\end{array}$ & $\begin{array}{l}\text { Severe } \\
\text { developm } \\
\text { ental } \\
\text { problems } \\
\text { resulting } \\
\text { in } \\
\text { incomplet } \\
\text { e data }\end{array}$ & $\begin{array}{l}\mathrm{V} \text { and } \\
\mathrm{U}\end{array}$ \\
\hline $\begin{array}{l}\text { Ferrari \& } \\
\text { Mauro } \\
\text { (2015) }\end{array}$ & $\mathrm{T}$ & $\begin{array}{l}\text { Assessme } \\
\text { nt of } \\
\text { photograp } \\
\text { hs }\end{array}$ & $\begin{array}{l}\text { Professi- } \\
\text { onals, } \\
\text { layperso } \\
\text { ns }\end{array}$ & $\begin{array}{l}23 \text { BCLP } \\
\text { patient } \\
\text { photogra } \\
\text { phs, } 10 \\
\text { cleft } \\
\text { professio } \\
\text { nals, } 10 \\
\text { non-cleft } \\
\text { professio } \\
\text { nals, } 5 \\
\text { layperson } \\
\text { s }\end{array}$ & $\begin{array}{l}19- \\
41 \\
\text { year } \\
\text { s }\end{array}$ & None & $\begin{array}{l}\text { Single } \\
\text { centre, } \\
\text { Brazil }\end{array}$ & $\begin{array}{l}\text { Under } 18 \\
\text { years of } \\
\text { age; non- } \\
\text { White } \\
\text { Brazilian } \\
\text { patients; } \\
\text { syndromi } \\
\text { c cleft; } \\
\text { not } \\
\text { complete } \\
\text { d all } \\
\text { treatment } \\
\text {; partly } \\
\text { treated at } \\
\text { another } \\
\text { centre }\end{array}$ & $\mathrm{U}$ \\
\hline $\begin{array}{l}\text { Gkantadi } \\
\text { s et al. } \\
\text { (2015) }\end{array}$ & $\mathrm{D}, \mathrm{S}, \mathrm{T}$ & $\begin{array}{l}\text { Structure } \\
\mathrm{d} \\
\text { interview }\end{array}$ & $\begin{array}{l}\text { Patients, } \\
\text { parents }\end{array}$ & $\begin{array}{l}33 \\
\text { patients, } \\
30 \\
\text { parents }\end{array}$ & $\begin{array}{l}9-33 \\
\text { year } \\
\text { s }\end{array}$ & None & $\begin{array}{l}\text { Single } \\
\text { centre, } \\
\text { Greece }\end{array}$ & $\begin{array}{l}\text { Under } 9 \\
\text { years of } \\
\text { age; } \\
\text { syndromi } \\
\text { c cleft; } \\
\text { other } \\
\text { congenita } \\
1 \\
\text { anomalie } \\
\text { s with } \\
\text { associate } \\
\text { d } \\
\text { malforma } \\
\text { tions; } \\
\text { moderate }\end{array}$ & $\mathrm{U}$ \\
\hline
\end{tabular}




\begin{tabular}{|c|c|c|c|c|c|c|c|c|c|}
\hline & & & & & & & & $\begin{array}{l}\text { to severe } \\
\text { mental } \\
\text { retardatio } \\
\mathrm{n}\end{array}$ & \\
\hline $\begin{array}{l}\text { Hamlet \& } \\
\text { Harcourt } \\
(2015)\end{array}$ & $\mathrm{E}, \mathrm{S}, \mathrm{T}$ & $\begin{array}{l}\text { Semi- } \\
\text { structured } \\
\text { interview }\end{array}$ & Patients & 6 patients & $\begin{array}{l}57- \\
82 \\
\text { year } \\
\text { S }\end{array}$ & None & $\begin{array}{l}\text { Advertise } \\
\text { ments, } \\
\text { UK }\end{array}$ & $\begin{array}{l}\text { Under the } \\
\text { age of } 55 \\
\text { years }\end{array}$ & IPA \\
\hline $\begin{array}{l}\text { Klinto et } \\
\text { al. (2015) }\end{array}$ & $\mathrm{D}$ & $\begin{array}{l}\text { Observati } \\
\text { on; } \\
\text { cognitive } \\
\text { assessme } \\
\text { nt }\end{array}$ & $\begin{array}{l}\text { Professi } \\
\text { onals }\end{array}$ & $\begin{array}{l}29 \text { UCLP } \\
\text { patients }\end{array}$ & $\begin{array}{l}5 \\
\text { year } \\
\text { s }\end{array}$ & $\begin{array}{l}20 \\
\text { controls }\end{array}$ & $\begin{array}{l}2 \text { centres, } \\
\text { Sweden }\end{array}$ & $\begin{array}{l}\text { Non- } \\
\text { Swedish } \\
\text { speaking; } \\
\text { syndromi } \\
\text { c cleft; } \\
\text { additional }\end{array}$ & $\mathrm{V}$ \\
\hline $\begin{array}{l}\text { Knight et } \\
\text { al. (2015) }\end{array}$ & $\mathrm{D}$ & $\begin{array}{l}\text { Question } \\
\text { naires }\end{array}$ & Parents & $\begin{array}{l}112 \\
\text { mothers }\end{array}$ & & & $\begin{array}{l}\text { Survey } \\
\text { data, USA }\end{array}$ & $\begin{array}{l}\text { Syndromi } \\
\text { c cleft; } \\
\text { unable to } \\
\text { speak or } \\
\text { read } \\
\text { English } \\
\text { or } \\
\text { Spanish; } \\
\text { child } \\
\text { born } \\
\text { outside of } \\
\text { the state }\end{array}$ & V \\
\hline $\begin{array}{l}\text { Krikken } \\
\text { et al. } \\
(2015)\end{array}$ & $\mathrm{E}$ & $\begin{array}{l}\text { Question } \\
\text { naires }\end{array}$ & $\begin{array}{l}\text { Patients, } \\
\text { parents }\end{array}$ & $\begin{array}{l}102 \\
\text { patients } \\
\text { and their } \\
\text { parents }\end{array}$ & $\begin{array}{l}4-21 \\
\text { year } \\
\mathrm{s}\end{array}$ & $\begin{array}{l}\text { Norm } \\
\text { data }\end{array}$ & $\begin{array}{l}\text { Single } \\
\text { centre, } \\
\text { The } \\
\text { Netherlan } \\
\text { ds }\end{array}$ & $\mathrm{x}$ & V \\
\hline $\begin{array}{l}\text { Lee et al. } \\
(2015)\end{array}$ & $\mathrm{D}$ & $\begin{array}{l}\text { Cognitive } \\
\text { assessme } \\
\text { nt, speech } \\
\text { assessme } \\
\text { nt }\end{array}$ & $\begin{array}{l}\text { Professi } \\
\text { onals }\end{array}$ & $\begin{array}{l}15 \\
\text { patients }\end{array}$ & $\begin{array}{l}6-8 \\
\text { year } \\
s\end{array}$ & $\begin{array}{l}15 \\
\text { controls }\end{array}$ & $\begin{array}{l}\text { Single } \\
\text { centre, } \\
\text { Malaysia }\end{array}$ & $\begin{array}{l}\text { English } \\
\text { not } \\
\text { dominant } \\
\text { language; } \\
\text { syndromi } \\
\text { c cleft }\end{array}$ & $\begin{array}{l}\mathrm{V} \text { and } \\
\mathrm{U}\end{array}$ \\
\hline $\begin{array}{l}\text { Lima et } \\
\text { al. }(2015)\end{array}$ & $E$ & $\begin{array}{l}\text { Question } \\
\text { naire }\end{array}$ & Patients & $\begin{array}{l}61 \\
\text { patients }\end{array}$ & $\begin{array}{l}\text { 7-17 } \\
\text { year } \\
\mathrm{s}\end{array}$ & $\begin{array}{l}61 \\
\text { controls }\end{array}$ & Brazil & $\mathrm{x}$ & V \\
\hline $\begin{array}{l}\text { Lorot- } \\
\text { Marchan } \\
\text { d et al. } \\
(2015)\end{array}$ & $\mathrm{D}, \mathrm{S}, \mathrm{T}$ & $\begin{array}{l}\text { Question } \\
\text { naires }\end{array}$ & Patients & $\begin{array}{l}55 \\
\text { patients }\end{array}$ & $\begin{array}{l}12- \\
29 \\
\text { year } \\
\text { s }\end{array}$ & None & $\begin{array}{l}3 \text { centres, } \\
\text { France }\end{array}$ & $\mathrm{x}$ & $\mathrm{U}$ \\
\hline $\begin{array}{l}\text { Pausch et } \\
\text { al. (2015) }\end{array}$ & $S$ & $\begin{array}{l}\text { Assessme } \\
\text { nt of } \\
\text { photograp } \\
\text { hs }\end{array}$ & $\begin{array}{l}\text { Medical } \\
\text { and non- } \\
\text { medical } \\
\text { layperso }\end{array}$ & $\begin{array}{l}50 \\
\text { patient } \\
\text { photogra } \\
\text { phs; } 273\end{array}$ & $\begin{array}{l}15- \\
48 \\
\text { year } \\
\text { s }\end{array}$ & None & $\begin{array}{l}\text { Single } \\
\text { centre, } \\
\text { Germany }\end{array}$ & $\begin{array}{l}\text { Syndromi } \\
\text { c cleft; } \\
\text { incomplet } \\
\text { e }\end{array}$ & $\mathrm{U}$ \\
\hline
\end{tabular}




\begin{tabular}{|c|c|c|c|c|c|c|c|c|c|}
\hline & & & ns & $\begin{array}{l}\text { medical } \\
\text { and non- } \\
\text { medical } \\
\text { layperson } \\
\mathrm{s}\end{array}$ & & & & $\begin{array}{l}\text { treatment } \\
\text { and } \\
\text { rehabilita } \\
\text { tion }\end{array}$ & \\
\hline $\begin{array}{l}\text { Petrackov } \\
\text { a et al. } \\
(2015)\end{array}$ & $\mathrm{D}, \mathrm{E}, \mathrm{T}$ & $\begin{array}{l}\text { Question } \\
\text { naires; } \\
\text { cognitive } \\
\text { assessme } \\
\text { nt }\end{array}$ & $\begin{array}{l}\text { Professi } \\
\text { onals, } \\
\text { parents }\end{array}$ & $\begin{array}{l}32 \\
\text { patients } \\
\text { and their } \\
\text { parents }\end{array}$ & $\begin{array}{l}3-7 \\
\text { year } \\
\text { s }\end{array}$ & $\begin{array}{l}\text { Norm } \\
\text { data }\end{array}$ & $\begin{array}{l}\text { Single } \\
\text { centre, } \\
\text { Czech } \\
\text { Republic }\end{array}$ & $\begin{array}{l}\text { No cleft } \\
\text { of the lip }\end{array}$ & $\mathrm{V}$ \\
\hline $\begin{array}{l}\text { Smillie } \\
(2015)\end{array}$ & $\mathrm{T}$ & $\begin{array}{l}\text { Retrospec } \\
\text { tive } \\
\text { clinical } \\
\text { review }\end{array}$ & $\begin{array}{l}\text { Professi } \\
\text { onals }\end{array}$ & $\begin{array}{l}74 \\
\text { patients } \\
\text { with cleft }\end{array}$ & $\begin{array}{l}16- \\
28 \\
\text { year } \\
\text { s }\end{array}$ & None & $\begin{array}{l}\text { Single } \\
\text { centre, } \\
\text { UK }\end{array}$ & & N/A \\
\hline $\begin{array}{l}\text { Stock, } \\
\text { Feragen } \\
\text { et al. } \\
(2015)\end{array}$ & $\begin{array}{l}\mathrm{D}, \mathrm{E}, \mathrm{S}, \\
\mathrm{T}\end{array}$ & $\begin{array}{l}\text { Semi- } \\
\text { structured } \\
\text { interview }\end{array}$ & Patients & $\begin{array}{l}52 \\
\text { patients }\end{array}$ & $\begin{array}{l}22- \\
77 \\
\text { year } \\
\text { s }\end{array}$ & None & $\begin{array}{l}\text { Advertise } \\
\text { ments, } \\
\text { UK }\end{array}$ & $\begin{array}{l}\text { Under } 18 \\
\text { years of } \\
\text { age }\end{array}$ & $\begin{array}{l}\text { Thema } \\
\text { tic } \\
\text { analysi } \\
\mathrm{s}\end{array}$ \\
\hline $\begin{array}{l}\text { Stock \& } \\
\text { Rumsey } \\
(2015)\end{array}$ & E, S, T & $\begin{array}{l}\text { Semi- } \\
\text { structured } \\
\text { interview }\end{array}$ & Patients & $\begin{array}{l}24 \\
\text { patients }\end{array}$ & $\begin{array}{l}28- \\
70 \\
\text { year } \\
\text { s }\end{array}$ & & $\begin{array}{l}\text { Advertise } \\
\text { ments, } \\
\text { UK }\end{array}$ & $\begin{array}{l}\text { Under } 18 \\
\text { years of } \\
\text { age; no } \\
\text { children }\end{array}$ & $\begin{array}{l}\text { Thema } \\
\text { tic } \\
\text { analysi } \\
\text { s }\end{array}$ \\
\hline $\begin{array}{l}\text { Tierney } \\
\text { et al. } \\
(2015)\end{array}$ & $\begin{array}{l}\mathrm{D}, \mathrm{B}, \\
\mathrm{E}, \mathrm{S}\end{array}$ & $\begin{array}{l}\text { Semi- } \\
\text { structured } \\
\text { interview; } \\
\text { participat } \\
\text { ory } \\
\text { activities }\end{array}$ & Pa & $\begin{array}{l}37 \\
\text { parents, } \\
22 \\
\text { patients }\end{array}$ & $\begin{array}{l}0-11 \\
\text { year } \\
\mathrm{s}\end{array}$ & None & $\begin{array}{l}2 \text { centres, } \\
\text { UK }\end{array}$ & $\begin{array}{l}\text { Syndromi } \\
\text { c cleft; no } \\
\text { experienc } \\
\text { e of } \\
\text { OME; } \\
\text { non- } \\
\text { English } \\
\text { speaking; } \\
\text { psychoso } \\
\text { cial } \\
\text { difficultie } \\
\text { s as } \\
\text { reported } \\
\text { by the } \\
\text { cleft team }\end{array}$ & $\begin{array}{l}\text { Frame } \\
\text { work } \\
\text { analysi } \\
\text { s }\end{array}$ \\
\hline $\begin{array}{l}\text { Aravena } \\
\text { et al, (in } \\
\text { press) }\end{array}$ & $\mathrm{D}, \mathrm{E}, \mathrm{S}$ & $\begin{array}{l}\text { Question } \\
\text { naire }\end{array}$ & Patients & $\begin{array}{l}48 \\
\text { patients }\end{array}$ & $\begin{array}{l}8-15 \\
\text { year } \\
\text { s }\end{array}$ & $\begin{array}{l}96 \\
\text { controls }\end{array}$ & $\begin{array}{l}3 \text { cities, } \\
\text { Chile }\end{array}$ & $\begin{array}{l}\text { Disabling } \\
\text { medical } \\
\text { condition } \\
\text {; } \\
\text { syndromi } \\
\text { c cleft; } \\
\text { mental } \\
\text { disorders }\end{array}$ & $\mathrm{V}$ \\
\hline $\begin{array}{l}\text { Feragen } \\
\text { Særvold } \\
\text { et al. (in } \\
\text { press) }\end{array}$ & $\mathrm{D}, \mathrm{E}, \mathrm{S}$ & $\begin{array}{l}\text { Question } \\
\text { naires; } \\
\text { speech } \\
\text { assessme } \\
\text { nt }\end{array}$ & $\begin{array}{l}\text { Patients, } \\
\text { parents, } \\
\text { professi } \\
\text { onals }\end{array}$ & $\begin{array}{l}170 \\
\text { patients, } \\
170 \\
\text { caregiver } \\
\text { s }\end{array}$ & $\begin{array}{l}10 \\
\text { year } \\
\mathrm{s}\end{array}$ & $\begin{array}{l}\text { Norm } \\
\text { data }\end{array}$ & $\begin{array}{l}\text { Single } \\
\text { centre, } \\
\text { Norway }\end{array}$ & $\begin{array}{l}\text { Severe } \\
\text { developm } \\
\text { ental } \\
\text { problems } \\
\text { resulting } \\
\text { in }\end{array}$ & $\begin{array}{l}\mathrm{V} \text { and } \\
\mathrm{U}\end{array}$ \\
\hline
\end{tabular}




\begin{tabular}{|c|c|c|c|c|c|c|c|c|c|}
\hline & & & & & & & & $\begin{array}{l}\text { incomplet } \\
\text { e data }\end{array}$ & \\
\hline $\begin{array}{l}\text { Feragen } \\
\& \text { Stock } \\
\text { (in press) }\end{array}$ & $\begin{array}{l}\text { D, B, } \\
\text { E, S, T }\end{array}$ & $\begin{array}{l}\text { Question } \\
\text { naires }\end{array}$ & $\begin{array}{l}\text { Patients, } \\
\text { parents }\end{array}$ & $\begin{array}{l}845 \\
\text { patients, } \\
722 \\
\text { caregiver } \\
\text { s }\end{array}$ & $\begin{array}{l}10 \\
\text { year } \\
\mathrm{s}\end{array}$ & $\begin{array}{l}\text { Norm } \\
\text { data }\end{array}$ & $\begin{array}{l}\text { Single } \\
\text { centre, } \\
\text { Norway }\end{array}$ & $\begin{array}{l}\text { Severe } \\
\text { developm } \\
\text { ental } \\
\text { problems } \\
\text { resulting } \\
\text { in } \\
\text { incomplet } \\
\text { e data }\end{array}$ & $\begin{array}{l}\mathrm{V} \text { and } \\
\mathrm{U}\end{array}$ \\
\hline $\begin{array}{l}\text { Kortelain } \\
\text { en et al. } \\
\text { (in press) }\end{array}$ & $\mathrm{G}$ & $\begin{array}{l}\text { Question } \\
\text { naire }\end{array}$ & Patients & $\begin{array}{l}26 \\
\text { patients }\end{array}$ & $\begin{array}{l}11- \\
14 \\
\text { year } \\
\text { s }\end{array}$ & $\begin{array}{l}71 \\
\text { controls }\end{array}$ & $\begin{array}{l}\text { Single } \\
\text { centre, } \\
\text { Finland }\end{array}$ & & V \\
\hline $\begin{array}{l}\text { Stock et } \\
\text { al. (in } \\
\text { press) }\end{array}$ & E, S, T & $\begin{array}{l}\text { Semi- } \\
\text { structured } \\
\text { interview }\end{array}$ & Patients & $\begin{array}{l}52 \\
\text { patients }\end{array}$ & $\begin{array}{l}22- \\
77 \\
\text { year } \\
\text { s }\end{array}$ & None & $\begin{array}{l}\text { Advertise } \\
\text { ments, } \\
\text { UK }\end{array}$ & $\begin{array}{l}\text { Under } 18 \\
\text { years of } \\
\text { age }\end{array}$ & $\begin{array}{l}\text { Thema } \\
\text { tic } \\
\text { analysi } \\
\text { s }\end{array}$ \\
\hline $\begin{array}{l}\text { Van } \\
\text { Schijndel } \\
\text { et al. (in } \\
\text { press) }\end{array}$ & S & $\begin{array}{l}\text { Assessme } \\
\text { nt of } \\
\text { photograp } \\
\text { hs }\end{array}$ & $\begin{array}{l}\text { Laypers } \\
\text { ons }\end{array}$ & $\begin{array}{l}18 \\
\text { patient } \\
\text { photogra } \\
\text { phs, } 40 \\
\text { layperson } \\
\text { s }\end{array}$ & $\begin{array}{l}16- \\
28 \\
\text { year }\end{array}$ & & $\begin{array}{l}\text { Single } \\
\text { centre, } \\
\text { The } \\
\text { Netherlan } \\
\text { ds }\end{array}$ & $\begin{array}{l}\text { Syndromi } \\
\text { c cleft }\end{array}$ & $\mathrm{U}$ \\
\hline
\end{tabular}

